RONALDO COELHO DE FREITAS

\title{
BENEFÍCIOS TÉCNICOS E ECONÔMICOS DA ADOÇÃO DE SIMULAÇÕES VIRTUAIS DOS PROCESSOS DE MONTAGEM
}

Trabalho de Curso apresentado à Escola Politécnica da Universidade de São Paulo para obtenção do título de Mestre em Engenharia Automotiva (Mestrado Profissionalizante).

São Paulo 
RONALDO COELHO DE FREITAS

\section{BENEFÍCIOS TÉCNICOS E ECONÔMICOS DA ADOÇÃO DE SIMULAÇÕES VIRTUAIS DOS PROCESSOS DE MONTAGEM}

Trabalho de Curso apresentado à Escola Politécnica da Universidade de São Paulo para obtenção do título de Mestre em Engenharia Automotiva (Mestrado Profissionalizante).

Área de Concentração:

Engenharia Automotiva (Mestrado Profissionalizante)

Orientador:

Prof. Dr. Ronaldo de Breyne Salvagni

São Paulo 


\section{DEDICATÓRIA}

A Luciene, minha esposa, pelo carinho e incentivo.

E a minha filha Isabela. 


\section{AGRADECIMENTOS}

Desejo expressar minha profunda gratidão à minha família, a quem devo minha educação e com a qual aprendi a lutar pelos meus objetivos.

Ao Prof. Dr. Paulino G. Francischini, pela confiança em mim depositada e pelos valiosos ensinamentos durante o período em que trabalhamos juntos.

Aos professores participantes do programa de Mestrado Profissionalizante em Engenharia Automotiva, pelos ensinamentos compartilhados durante o curso.

Aos amigos e colegas de trabalho da GMB, cuja colaboração e estímulo foram imprescindíveis na concretização deste trabalho.

Aos diretores e gerentes da General Motors do Brasil, e a todos que se empenharam no difícil processo de viabilização deste curso dentro da empresa, pela oportunidade para o meu desenvolvimento profissional e pessoal. 


\section{RESUMO}

O objetivo dessa pesquisa é responder à pergunta: Como as áreas de projetos e processos de empresas fabricantes de veículos automotivos podem se beneficiar dos softwares simuladores de montagem, durante as fases de projeto do produto e especificações dos processos a serem utilizados?

O escopo desse trabalho está localizado na utilização de softwares de simulação virtual para análise das condições de montagem e detecção de possíveis interferências dos equipamentos de montagem durante o desenvolvimento de novos produtos.

A validação deste trabalho será feita através da análise de dois estudos de caso. Para a coleta de dados serão realizadas entrevistas semi-estruturadas com a utilização de um roteiro para a pesquisa de campo, aplicadas diretamente aos usuários dos processos de simulação da Engenharia de Processos de Montagem de Veículos da General Motors do Brasil.

De posse dos conceitos obtidos pela revisão bibliográfica e pela pesquisa de campo, pudemos analisar os benefícios técnicos e econômicos da adoção das simulações virtuais dos processos de montagem e confirmar a validade das proposições estabelecidas: contribuição para a redução de custos adicionais em equipamentos de montagem e o aumento da detecção de interferências dimensionais entre partes e equipamentos numa montagem, durante a fase de projeto. 


\begin{abstract}
The research objective is to answer what can be an assembly process strategy in automotive companies to make use of virtual simulation over development product phase.

The scope of this study is to use virtual simulation to analyze the assembly condition and detect interferences between assembly equipment and product parts or components during development phase.

In this report we studied two cases in order to register the facts. Thus, some interviews and a semi-structured questionnaire were answered for General Motors do Brasil software simulation users.

Making an analysis with the concept from literature and field investigation, the research shows the technical and economical virtual simulation advantages in the assembly process. Concluding, we could validate the two propositions: cost reduction with additional assembly equipment related and increase problem solving actions due product and process tooling interferences during design phase.
\end{abstract}




\section{SUMÁRIO}

Lista de Figuras

Lista de Tabelas

Lista de Abreviaturas e Siglas

CAPÍTULO 1 - DEFINIÇÃO DA PESQUISA .....................................2

1.1 Introdução ....................................................... 2

1.2 Identificação do problema ......................................... 3

1.3 Objetivos......................................................... 4

CAPÍTULO 2 - REVISÃO BIBLIOGRÁFICA ........................................6

2.1 Simulação........................................................6

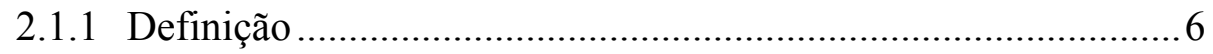

2.1.2 Modelagem da Simulação ...................................................... 6

2.1.3 Processo de Simulação ............................................................. 7

2.1.4 Classificação do Modelo de Simulação ....................................... 8

2.1.5 Aplicações da Simulação ......................................................... 9

2.2 Simulações Virtuais na Manufatura ............................... 10

2.2.1 Potenciais contribuições da Manufatura Virtual ......................... 11

2.2.2 Alguns exemplos de aplicações da MV .................................... 11

2.3 O Processo de Desenvolvimento de Produtos..................... 12

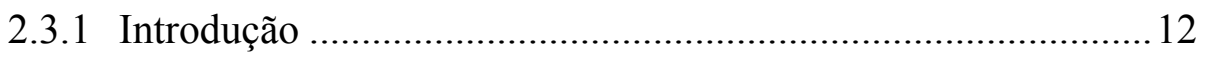

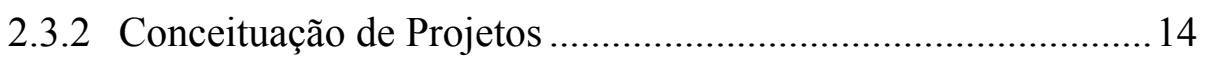

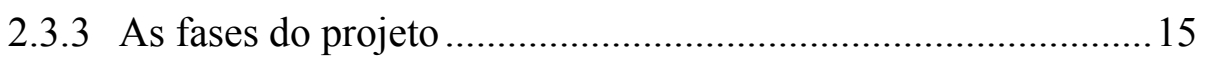

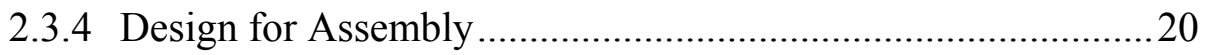

2.4 Processos de Montagem ........................................ 22

2.4.1 Definição de Montagem ..........................................................22

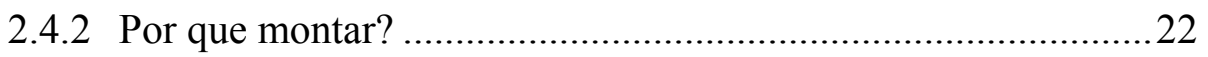

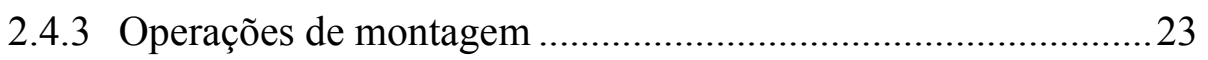

2.4.4 Equipamentos de montagem ................................................ 24

2.5 Interferências dos equipamentos de montagem................... 25 
CAPÍTULO 3 - METODOLOGIA DA PESQUISA...............................28

3.1 Introdução ...................................................... 28

3.2 Abordagem da Pesquisa........................................ 28

3.3 Classificação da Pesquisa............................................. 29

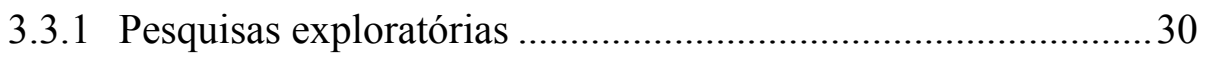

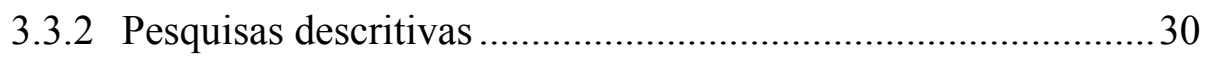

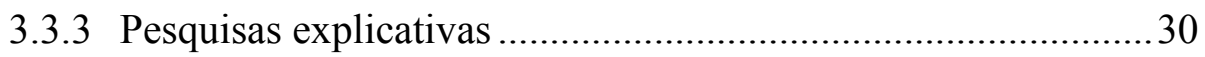

3.4 Métodos de pesquisa............................................ 31

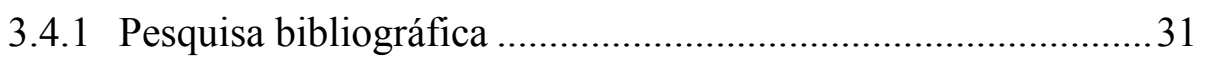

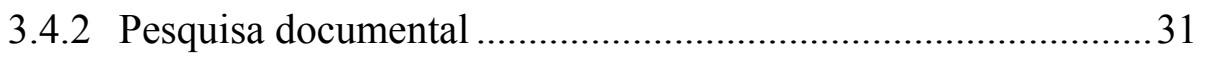

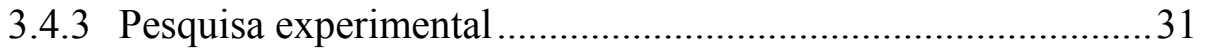

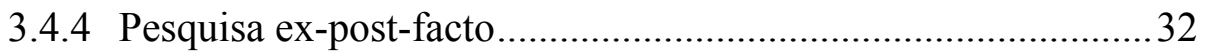

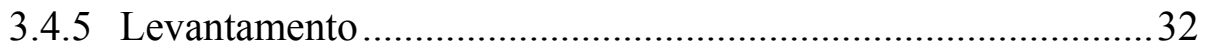

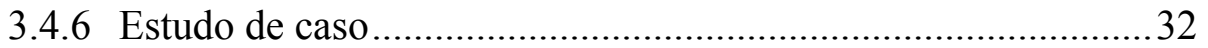

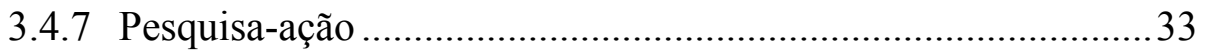

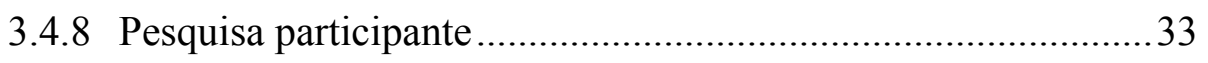

3.5 Resumo da metodologia de pesquisa ............................ 34

CAPÍTULO 4 - PLANO DE PESQUISA ............................................36

4.1 Introdução ....................................................... 36

4.2 Elaboração da Pesquisa ............................................... 39

4.3 Delimitação da Unidade-caso ........................................ 39

4.4 Instrumento de coleta de dados ................................... 40

4.5 Pré-teste do questionário-roteiro................................. 42

4.6 Seleção dos casos ........................................... 43

4.6.1 Estudo de Caso A: análise do não-uso de simulações no Projeto A16 ...44

4.6.2 Estudo de Caso B: análise do uso de simulações no Projeto A03 ............44

4.7 Coleta e verificação dos dados ...................................... 45

4.8 Análise e interpretação dos dados ................................. 45

CAPÍTULO 5 - PESQUISA DE CAMPO E ANÁLISE CRÍTICA.......47

5.1 Caracterização da Empresa ..................................... 47

5.2 A unidade de análise: Engenharia de Processos de 
5.3 GVDP: O Processo de Desenvolvimento de Produtos da GM.... 48

5.4 Os meios de troca de Informações e Gerenciamento de Dados ... 53

5.5 Procedimentos para a Simulação Virtual.......................... 55

5.6 Os estudos de caso................................................ 57

5.7 Os dados levantados ............................................. 60

5.7.1 Estudo de Caso A: Projeto A16 .................................................60

5.7.2 Estudo de Caso B: Projeto A03 ................................................65

CAPÍTULO 6 - CONCLUSÕES ..........................................................75

6.1 Análise das proposições....................................... 75

6.2 Limitações ........................................................ 76

6.3 Sugestões para pesquisas futuras .............................. 77

6.4 Considerações finais .............................................. 78

ANEXO A - Questionário para pesquisa de campo sobre a utilização de Simulações Virtuais na Manufatura da GMB. 79

ANEXO B - Estudo de Caso A: A detecção de interferências de montagem no Projeto A16, sem o uso de simulações virtuais. 85

ANEXO C - Estudo de Caso B: A adoção de simulações virtuais no Projeto A03, para detecção de interferências de montagem.

REFERÊNCIAS BIBLIOGRÁFICAS.................................................98 


\section{LISTA DE FIGURAS}

Figura 2.1 Escopo do desenvolvimento de produtos................................................... 13

Figura 2.2 Exemplo genérico do Ciclo de Vida do Projeto ...................................... 16

Figura 2.3 Desenvolvimento de produtos por times multidisciplinares.................... 19

Figura 2.4 Etapas dos estudos de engenharia simultânea usando técnicas de DFM/A ...21

Figura 2.5 Estrutura típica de um produto montado.................................................23

Figura 2.6 Operações do processo de montagem ....................................................24

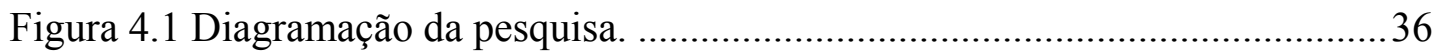

Figura 5.1 Organograma da Enga de Manufatura...................................................48

Figura 5.2 O plano do processo de desenvolvimento de veículos da GMB (modificado). 52

Figura 5.3 Fluxo de dados da simulação virtual.........................................................54

Figura 5.4 Máscara para relatório da simulação virtual ..........................................57

Figura 5.5 A detecção de interferências em dois projetos, antes e após as simulações virtuais ....60

Figura 5.6 Local da detecção de interferências no Projeto A16.................................61

Figura 5.7 Fatores considerados na resolução de interferências no Projeto A16.......62

Figura 5.8 A aplicação de simulações virtuais na Enga Processos de Montagem......65

Figura 5.9 Momento mais adequado para uso das simulações .................................67

Figura 5.10 Divulgação dos requisitos de montagem ............................................6 68

Figura 5.11 Local da detecção de interferências no Projeto A03..............................69

Figura 5.12 Fatores considerados na solução de interferências no Projeto A03 ........69

Figura 5.13 Dificuldades do processo de simulação ................................................. 70

Figura 5.14 Propostas para estimular o uso de simulações ....................................... 71 


\section{LISTA DE TABELAS}

Tabela 2.1 Algumas áreas de aplicação de técnicas de simulação............................. 9

Tabela 2.2 Organização e gerenciamento de projetos subdivididos em fases ........... 17

Tabela 3.1 Quadro resumo do processo de escolha do método de pesquisa...............34

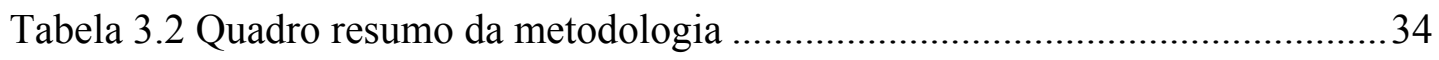

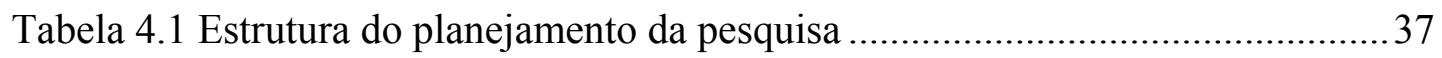

Tabela 5.1 Análise comparativa dos recursos utilizados nos projetos A16 e A03.....58

Tabela 5.2 Quadro resumo do Estudo de Caso A - Projeto A16 .................................63

Tabela 5.3 Outras melhorias pretendidas com o uso de simulações virtuais ..............66

Tabela 5.4 Quadro resumo do Estudo de Caso B - Projeto A03 ...............................72

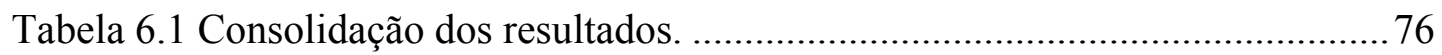




\section{LISTA DE ABREVIATURAS E SIGLAS}

CKD: Completely Knocked Down

DFM/A: Design for Manufacture and Assembly

DMU: Digital Mock-up

FMEA: Failure Mode and Effect Analysis

GMB: General Motors do Brasil

GVDP: Global Vehicle Development Process

iMAN: Information Manager

MV: Manufatura Virtual

PV: Product Vision

UG: Unigraphics

VAS: Virtual Analysis and Simulation 


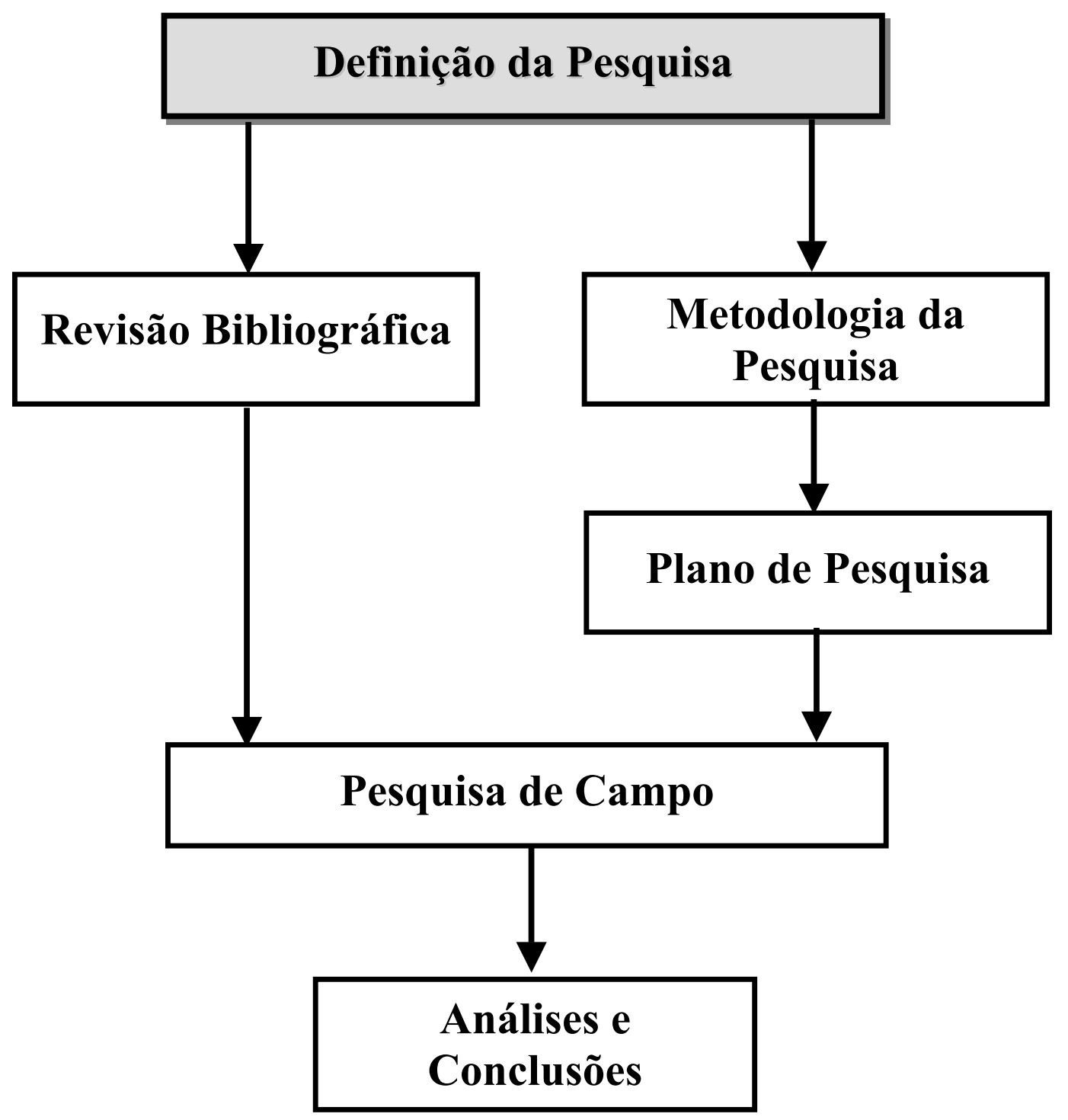




\section{CAPÍTULO 1 - DEFINIÇÃO DA PESQUISA}

\subsection{Introdução}

O mundo já passou por várias fases: agrícola, mercantil, e hoje o que prevalece é a informação. A utilização e manipulação das informações, aliada ao processo de globalização das relações econômicas, exigem das empresas uma nova postura mercadológica.

Neste novo cenário de globalização e abertura dos mercados, a sobrevivência da empresa, seja ela multinacional ou de menor porte, está relacionada à sua capacidade competitiva e suas abilidades na disputa pela preferência dos consumidores. Deve buscar atingir um melhor desempenho global, especialmente no que se refere às variáveis qualidade, custo e flexibilidade, procurando obter vantagens competitivas em relação aos concorrentes e, consequentemente, tornar-se atraente para os consumidores. As empresas passaram a investir em novos processos de manufatura, em novas técnicas para aumentar a qualidade e em novas tecnologias para se tornarem flexíveis.

No setor automobilístico o cenário não é diferente, e a competitividade está cada vez mais acirrada. Em busca de vantagens competitivas, as empresas estão vivenciando um processo de redescoberta da área de desenvolvimento de produtos. A indústria automobilística quer reduzir o seu tempo de desenvolvimento, aumentar a qualidade de seu produto e diminuir os custos de projeto.

O avanço da tecnologia fez com que surgissem novos equipamentos, novos materiais e processos produtivos, provocando um aumento nas possibilidades de desenvolvimento de novos produtos. A indústria automobilística está implementando novas tecnologias de desenvolvimento para que os processos ocorram cada vez mais de forma simultânea, fazendo com que as informações estejam disponíveis e sejam realmente analisadas pelas áreas envolvidas no processo de desenvolvimento de um novo produto. 


\subsection{Identificação do problema}

A crescente disponibilidade de recursos computacionais desenvolvidos para as mais diversas aplicações na indústria automobilística têm proporcionado grande avanço no processo de desenvolvimento de novos produtos, bem como na melhoria dos sistemas produtivos atuais.

A Corporação GM enxerga essa revolução tecnológica pela qual o mundo atravessa e está sempre buscando a maximização do uso desses recursos. E nessa direção, ela quer tornar comum os processos e sistemas de todas suas Engenharias pelo mundo, a fim de que, num futuro próximo e planejado, venham a integrar um único sistema global pelo qual todos os dados, processos e padronizações sejam transparentes e acessíveis por qualquer Unidade sua, fazendo frente à concorrência que anuncia reduções substanciais em despesas de Engenharia.

Atualmente as informações de Engenharia são tridimensionais e matemáticas ou "Math-Based". O papel e o modelo físico foram reduzidos ao mínimo. A Engenharia não desenha mais, modela. Os modelos de Engenharia, sempre que possível, não são mais físicos: são matemáticos. Não são reais: são virtuais. A tridimensionalidade garante a consistência das informações na interação dos dados, enquanto a aplicação de funções sobre eles nos dá a simulação e a validação de processos de Manufatura sobre os modelos tridimensionais da fábrica, no mundo virtual. Isso é a "Virtual Factory". Processos e sistemas comuns, com todos os dados de Produto e Manufatura num único "silo" de dados, os "data warehouses", permitirão às Engenharias pelo mundo interagirem no desenvolvimento de novos produtos.

A partir dessas informações, a aplicação da tecnologia de simulação tornase uma importante ferramenta para o desenvolvimento de produtos, onde a Engenharia de Manufatura pode participar mais ativamente e antecipadamente, avaliando o projeto e seus processos produtivos de forma virtual, reduzindo os custos de modificações do projeto e/ou processos. 


\subsection{Objetivos}

Os objetivos dessa pesquisa visam a análise e aplicação das recentes ferramentas computacionais de simulação de montagem de peças e componentes automotivos durante as fases de projeto do produto e especificações dos processos de montagem que serão utilizados.

A aplicação desses softwares simuladores tem a principal vantagem de definir qual o melhor processo de fabricação e montagem do produto de acordo com todas as variações de produto e processo envolvidas. Isso significa otimizar a validação dos processos para assegurar que essas variações não interfiram no processo de fabricação.

O feedback dos engenheiros de Manufatura é crucial no estágio de concepção do produto para prover suporte aos projetistas e estabelecer os requisitos do planejamento do processo de fabricação, otimizando custos de investimento na área produtiva e força de trabalho requerida na produção.

Esse feedback da Manufatura somente será possível se ela estiver preparada para acompanhar de forma simultânea e integral a todas as propostas do projeto que afetam seus processos produtivos, analisando e retornando seus requisitos aos projetistas antes da conclusão do trabalho e liberação dos desenhos.

Neste trabalho iremos discutir como a Engenharia de Processos de Montagem de Veículos está se preparando para esse acompanhamento durante o projeto do produto, através das simulações virtuais de montagem e os benefícios a serem alcançados, ou seja, buscamos responder a seguinte pergunta:

Como as áreas de projetos e processos de empresas fabricantes de veículos automotivos podem se beneficiar dos softwares simuladores de montagem, durante as fases de projeto do produto e especificações dos processos a serem utilizados?

Para responder a essa pergunta, foram estabelecidas as seguintes proposições: 
$\mathbf{H}_{1}$ : "O crescimento da aplicação de simulações virtuais em projetos de veículos contribui para a redução de custos adicionais em equipamentos de montagem, novos ou retrabalhos de existentes".

$\mathbf{H}_{2}$ : "O crescimento da aplicação de simulações virtuais em projetos de veículos aumenta a detecção de interferências dimensionais entre partes e equipamentos numa montagem, durante a fase de projeto".

Os dados relevantes para a determinação da validade destas proposições serão coletados a partir de uma pesquisa de campo estruturada, com a análise de dois estudos de caso. Basicamente, buscamos avaliar as condições de montagem do produto e os custos e prazos para a eliminação de interferências dimensionais entre partes e equipamentos através de modificações no produto ou dos equipamentos de montagem. Estes dados estão relacionados com o momento de detecção dos problemas dentro dos cronogramas dos projetos ou seja, no caso A, durante a montagem dos protótipos físicos e o no caso $\mathrm{B}$, durante o projeto e criação dos protótipos virtuais .

De posse dos conceitos obtidos pela revisão bibliográfica e pela pesquisa de campo, poderemos fazer uma análise crítica dos casos estudados e tirar as conclusões dos objetivos propostos por este trabalho. 


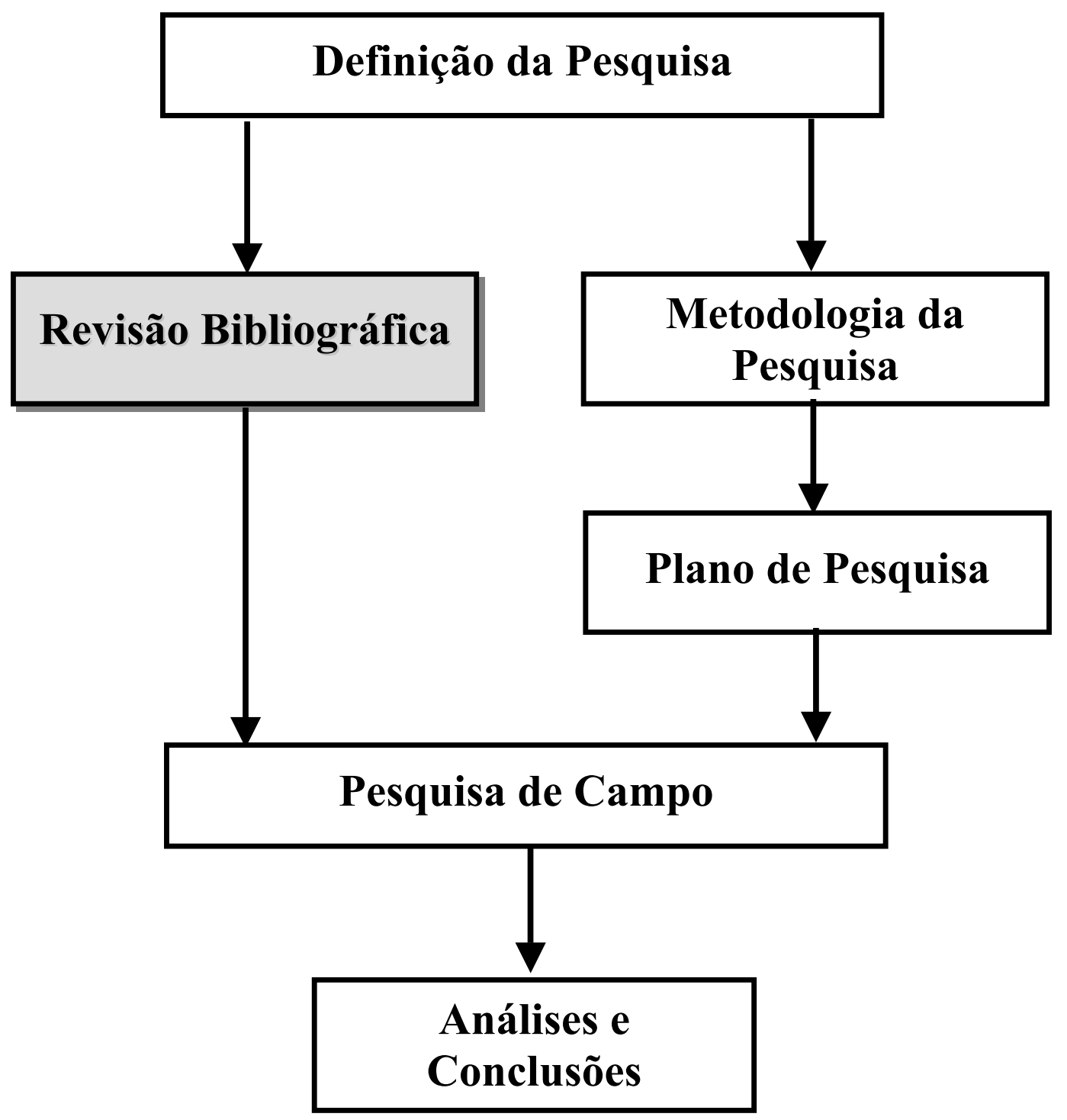




\section{CAPÍTULO 2 - REVISÃO BIBLIOGRÁFICA}

\subsection{Simulação}

\subsubsection{Definição}

Conforme define o Dicionário Oxford (apud Carrie, 1988), simulação é a "técnica de imitar o comportamento de alguma situação ou sistema por meio de situações análogas, modelos ou aparatos, com a finalidade de obter informações mais convenientes ou para treinar pessoas".

Segundo Pritsker (1986), a simulação computacional é o processo de desenvolvimento de um modelo matemático lógico que representa um sistema real para ser experimentado com o uso de computadores. Assim, a simulação envolve a construção de um modelo apropriado e que contenha as características do projeto e do processo em experimento. Esses experimentos, ou simulações, permitem extrair deduções sobre os sistemas:

- Sem a construção dos mesmos, se estes são apenas propostas.

- Sem distúrbios dos mesmos, se estes são sistemas em operação cujo custo ou risco de experimento é muito alto.

- Sem destruí-los, se o objeto de experimento é a determinação dos limites de resistência mecânica.

Dessa forma, modelos de simulação podem ser usados para projetos, procedimentos de análise e estudo do comportamento de sistemas.

\subsubsection{Modelagem da Simulação}

Um modelo é a descrição de algum sistema com a finalidade de conhecer seu comportamento quando certas ações são tomadas (Bratley; Fox; Schrage, 1993). As fronteiras do sistema real e do modelo devem ser definidas a fim de manter o modelo sob controle quando forças externas são exercidas no sistema. Para que um 
modelo seja útil, é essencial que seu comportamento e propriedades relevantes possam ser determinados de modo prático, seja analiticamente, numericamente ou dirigindo o modelo com certas entradas aleatórias e observando as saídas correspondentes. Este último processo é chamado simulação.

A modelagem da simulação presume que o sistema pode ser descrito em termos aceitáveis ao sistema computacional, sendo primordial a descrição do estado do sistema. Se um sistema pode ser caracterizado por um conjunto de variáveis com cada combinação das variáveis representando um único estado ou condição do sistema, então a manipulação dos valores simula o movimento do sistema de um estado para outro. $O$ experimento de simulação envolve a observação do comportamento dinâmico do modelo pela movimentação de estado para estado durante a operação do modelo.

\subsubsection{Processo de Simulação}

O sucesso no desenvolvimento de um modelo de simulação consiste em iniciar com um modelo o mais simples possível e que, no entanto, representa os requisitos necessários para a resolução do problema. Dentro deste processo, Pritsker (1986) identifica os seguintes estágios:

1. Formulação do problema: definição do problema a ser estudado, incluindo os objetivos da solução do mesmo.

2. Construção do modelo: a abstração do sistema em relações matemáticas lógicas de acordo com a formulação do problema.

3. Coleta de dados: a identificação, especificação e aquisição dos dados.

4. Tradução do modelo: a preparação do modelo para processamento por computador.

5. Verificação: estabelecimento de que o computador executa o programa como desejado.

6. Validação: processo de checagem da correspondência e precisão entre o modelo de simulação e o sistema real. 
7. Planejamento estratégico e tático: estabelecimento de condições experimentais para uso do modelo.

8. Experimento: a execução do modelo de simulação para obtenção dos resultados.

9. Análise dos resultados: processo de análise dos resultados da simulação para traçar conclusões e recomendações para a resolução do problema.

10. Implementação e documentação: implementação das decisões resultantes da simulação e documentação do modelo e seu uso.

\subsubsection{Classificação do Modelo de Simulação}

Os modelos de sistemas podem ser classificados em mudanças discretas ou contínuas. Na maioria das simulações o tempo é a maior variável independente. Outras variáveis normalmente inclusas na simulação são funções do tempo e são variáveis dependentes. Os adjetivos "discreto" e "contínuo" referem-se ao comportamento das variáveis dependentes (Pritsker, 1986).

\subsubsection{Modelagem de Simulação Discreta}

Tem por objetivo reproduzir as atividades das entidades da superfície de controle, tais como pessoas, equipamentos, pedidos de compra, matéria-prima e entender o comportamento potencial do sistema. Isso é feito pela definição dos estados do sistema e construção das atividades que movem de um estado para outro. Este estado do sistema é definido em termos de valores numéricos designados aos atributos das entidades das superfícies de controle. Assim, a simulação é o retrato dinâmico dos estados do sistema com o decorrer do tempo.

Na simulação discreta, o estado do sistema pode variar somente nos pontos específicos de tempo, permanecendo constante entre os períodos de tempo, o que permite a obtenção de um retrato completo da simulação dinâmica através do avanço do tempo de um evento para outro. 


\subsubsection{Modelagem de Simulação Contínua}

No modelo de simulação contínua, o estado do sistema é representado por variáveis dependentes às quais mudam continuamente com o tempo de simulação. Este modelo é construído a partir de equações, geralmente diferenciais, para o conjunto de variáveis de estado cujo comportamento dinâmico simula o sistema real.

\subsubsection{Modelagem de Simulação Combinada: Discreta e Contínua}

Nos modelos de simulação combinada, as variáveis podem mudar discreta ou continuamente. Nestes modelos, o sistema pode ser descrito em termos das entidades da superfície de controle, seus atributos associados e o estado das variáveis. O comportamento do sistema é simulado pela computação dos valores das variáveis de estado, em pequenos incrementos de tempo, e dos valores dos atributos das entidades no tempo.

\subsubsection{Aplicações da Simulação}

A simulação é uma técnica de pesquisa e gerenciamento de operações largamente empregada pela indústria e instituições governamentais. Tem sido usada nos estudos dos mais variados sistemas, como sistemas urbanos, de negócios, econômicos, produtivos, biológicos, sociais, de transporte, de saúde e muitos outros. A tabela abaixo apresenta algumas áreas de uso das técnicas de simulação:

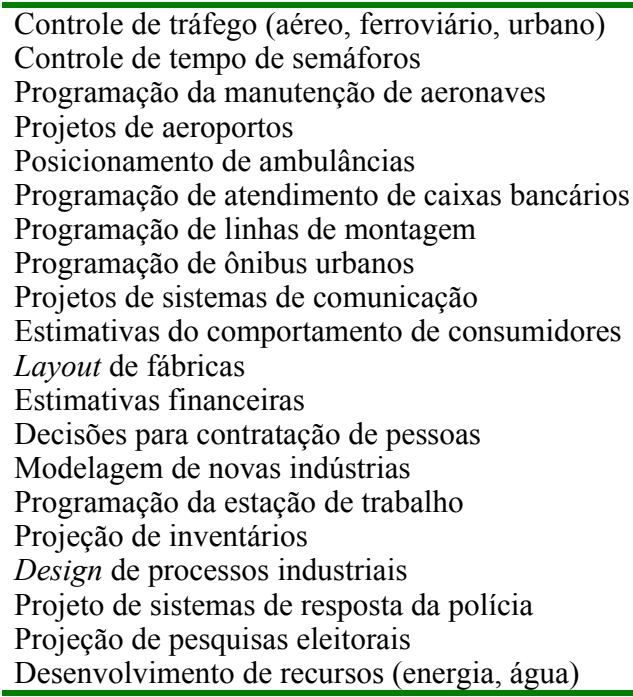

Tabela 2.1 Algumas áreas de aplicação de técnicas de simulação. (Pritsker, 1986). 
$\mathrm{O}$ contínuo desenvolvimento da linguagem de simulação aliado à flexibilidade da modelagem dos sistemas são fatores responsáveis pela crescente expansão dessa técnica.

\subsection{Simulações Virtuais na Manufatura}

As pressões da competitividade global estão forçando as empresas manufatureiras a acelerarem os ciclos de introdução de novos produtos e simultaneamente a reduzirem os custos totais do produto.

A integração do projeto em computador (virtual) com componentes de sistemas padronizados (físico) permite ao projetista analisar e otimizar o projeto antes da construção de qualquer componente.

Banks; Carson; Nelson (1995) mostra várias vantagens em que a aplicação da simulação trás para a Manufatura:

- Novas políticas, procedimentos operacionais, regras de projetos, fluxo de informação e procedimentos organizacionais podem ser explorados sem perturbar a continuidade das operações do sistema real.

- Novos projetos de equipamentos, arranjos físicos e sistemas de transporte podem ser testados sem a necessidade de utilizar os recursos existentes ou fazer aquisições.

- Hipóteses de "como" e "por que" certos fenômenos ocorrem podem ser testados para verificar a viabilidade.

- Tempo pode ser comprimido ou expandido, permitindo o aumento ou a redução da velocidade do fenômeno de investigação.

- Estudo da simulação pode ajudar o entendimento de como o sistema opera em vez de como os indivíduos pensam que o sistema opera. 


\subsubsection{Potenciais contribuições da Manufatura Virtual}

Espera-se que a Manufatura Virtual (MV), quando amadurecida, auxilie na avaliação dos requisitos de manufatura para um produto em desenvolvimento e forneça estimativas precisas para tempo de montagem, tempos de ciclo, tempos de set-up e custos, bem como qualidade do produto. Isto devido a MV ser capaz de modelar os processos empregados na fabricação do produto e o processo produtivo. E mais, se estes modelos de processos são capazes de prever as variações dos atributos característicos do produto, então a qualidade do processo produtivo pode ser comparada com os valores de tolerâncias de projeto. A MV permite a validação da manufaturabilidade do produto através da análise crítica dos requisitos de manufatura, tais como acesso e folgas de montagem, análise ergonômica e da confirmação das soluções de engenharia.

A validação do processo será obtida pela inclusão dos requisitos dimensionais e itens de DFM/A, assunto que será abordado mais adiante. A montagem virtual dos componentes de um produto permitirá a confirmação das soluções de Engenharia.

A Manufatura Virtual também permite a análise da célula de trabalho, sendo possível a simulação da interface "homem-máquina-produto" e verificação da disposição de equipamentos, robôs e operadores no layout.

\subsubsection{Alguns exemplos de aplicações da MV}

Como exemplificação do que foi exposto na seção anterior, segue alguns exemplos de aplicações que ilustram a potencial contribuição da Manufatura Virtual no processo integrado de desenvolvimento produtos:

- Validação do processo na fabricação de peças e componentes: usualmente a validação dos planos de processo é feita a partir da construção de protótipos, um procedimento caro e demorado. A validação do processo no computador elimina os altos custos de fabricação de protótipos, auxilia estimar precisamente os tempos de manufatura da peça ou componente e os custos envolvidos, além de 
fornecer medições importantes, como qualidade do projeto. Os dados obtidos da simulação serão usados para determinar as condições ideais de fabricação da peça e os pontos passíveis de melhorias. De posse dessas informações, o projetista poderá modificar o projeto para melhorar a manufaturabilidade, e o processista sintonizar os parâmetros dos equipamentos para otimizar ou melhorar o processo.

- Especificações do processo durante o projeto: a construção de processos virtuais irá possibilitar analisar a manufaturabilidade de acordo com as características do produto, avaliar o tempo de processo, o custo e a qualidade do produto manufaturado e suportar a otimização de performance do processo.

- Otimização do processo produtivo: diversas linguagens e pacotes de softwares de simulação por eventos discretos tem sido desenvolvidos para aplicação nas atividades de produção da área de manufatura, especialmente no planejamento e controle da produção, visando otimizar estoques, minimizar inventário e controlar os custos.

Algumas limitações ainda existem, porém se trabalhadas efetivamente, a simulação tem grande potencial para permitir significativa contribuição ao gerenciamento de operações e de desenvolvimento do produto e do processo. A simulação não é efetiva em dois casos: de produção por pequenos lotes de vários produtos e de sistemas just-in-time.

\subsection{O Processo de Desenvolvimento de Produtos}

\subsubsection{Introdução}

A definição mais comum e convencional do processo de desenvolvimento de produtos está na parte superior da figura 2.1. As informações estratégicas da empresa eram desenvolvidas pela alta cúpula e área de marketing e enviadas para a engenharia preparar as especificações de produto. Somente depois estas informações eram endereçadas à manufatura para preparar as especificações do processo e realizar seu trabalho (Rozenfeld; Amaral, 2000). 
Mas esse processo tem-se modificado bastante no novo escopo do desenvolvimento de produtos, onde os consumidores estão se tornando cada vez mais sofisticados e exigentes, ditando o quê, onde, e como eles querem comprar produtos e serviços. Não são mais consumidores passivos, recebedores de produtos e serviços. Hoje eles ditam o design, a manufatura e a distribuição desses produtos e serviços.

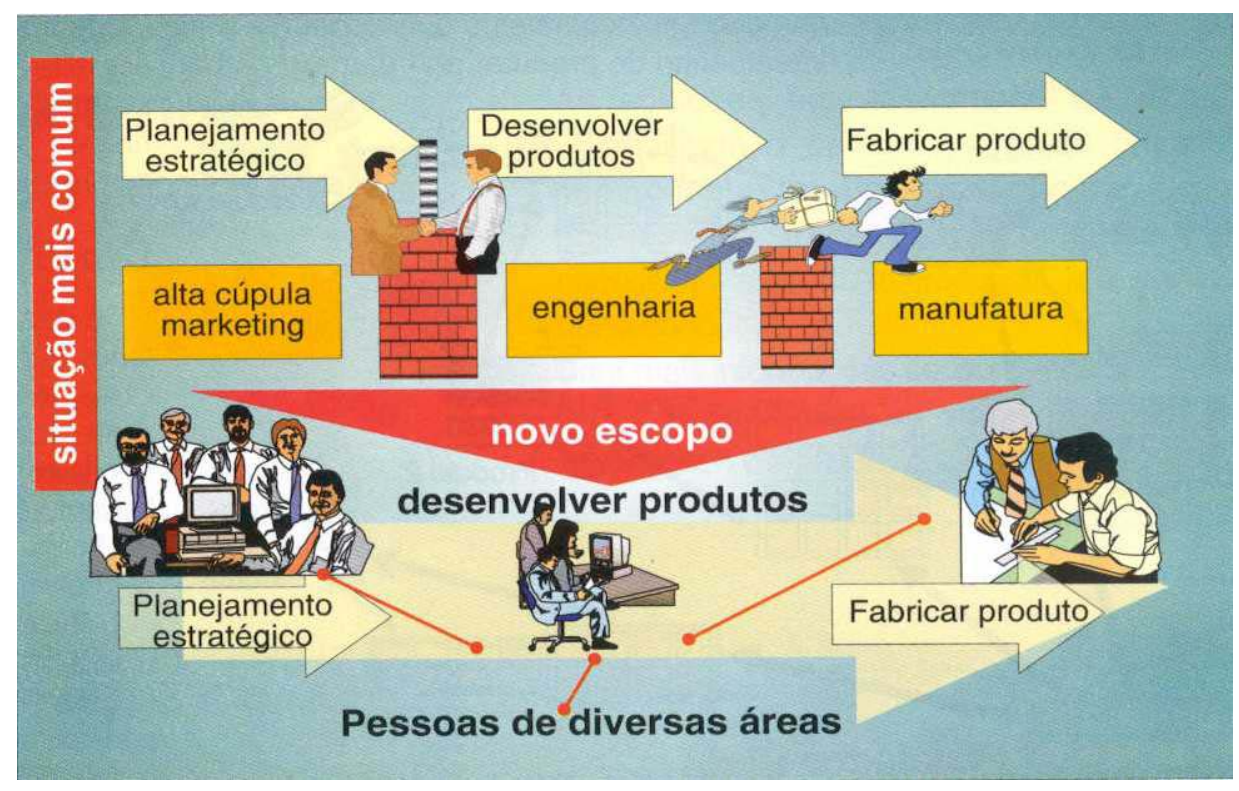

Figura 2.1 Escopo do desenvolvimento de produtos (Rozenfeld, 2000).

Sendo assim, espera-se que cada vez mais se incorporem ao desenvolvimento de produtos as atividades ligadas à produção, lançamento e acompanhamento do produto no mercado. Permite-se, dessa forma, que requisitos do cliente e da sociedade, aspectos técnicos e problemas encontrados nos produtos em campo sejam continuamente compilados e alimentem rapidamente o planejamento e as decisões realizadas durante o desenvolvimento dos novos produtos. As pessoas deixam de fazer parte de departamento fechados e tornam-se membros de times, que agregam pessoas de diversas áreas. 


\subsubsection{Conceituação de Projetos}

Projetos são atividades organizadas, desenvolvidas para encontrar uma necessidade ou prover a solução de um problema identificado, melhorando as condições de indivíduos, grupos ou empresas (Frankel, 1990).

Usualmente os projetos são desenvolvidos após escolha da melhor alternativa de projeto, em função dos métodos e tecnologias empregadas para atingir os objetivos desejados.

São características específicas de um projeto: relativo curto prazo para desenvolvimento e implementação, datas definidas para início e término, as atividades são geralmente únicas e não-rotineiras, e orçamentos e recursos limitados.

Segundo Kaminski (2000), a diversificação dos projetos requer gerenciamento também diferenciado, pois cada projeto segue um conjunto de especificações diferentes desde a identificação das necessidades dos clientes até a finalização do mesmo. Os produtos resultantes dos projetos são disponibilizados aos clientes essencialmente para satisfazer necessidades humanas individuais ou coletivas, sendo influenciados por fatores tecnológicos, econômicos, humanos e ambientais. Os projetos também estão relacionados com a sociedade a que se destinam, a qual influenciam no desenvolvimento dos mesmos e que, por outro lado, geram novas necessidades, hábitos e costumes.

Para assegurar a inclusão de todo trabalho necessário para completar de forma bem sucedida o projeto, define-se o escopo do projeto, que de forma simples, compreende definir e controlar o que está ou não incluído no projeto. Deve ser definido em termos de:

- Problemas que o projeto deve solucionar.

- Especificação detalhada dos problemas.

- Tolerância de aceitação da solução encontrada.

- Dificuldades a serem enfrentadas quanto a recursos e prazos.

- Identificação das propostas rejeitadas e limitação do escopo do projeto. 
A partir das características de cada produto concebido, Kaminski (2000) diferencia dois tipos de projetos:

Projetos por evolução: aqueles nos quais as descobertas científicas e tecnológicas são agregadas a modelos precedentes, sem que haja entretanto modificações radicais nos princípios tecnológicos do produto.

Projetos por inovação: as condições de mercado são geralmente rompidas pelas pressões competitivas, com soluções expressivamente novas, que utilizam as últimas descobertas tecno-científicas.

\subsubsection{As fases do projeto}

$\mathrm{Na}$ sua maioria, os projetos e programas de engenharia são muito complexos para serem gerenciados efetivamente em uma única etapa, devido a grande dificuldade de planejamento e controle dos elementos técnicos, organizacionais e humanos.

A decomposição de um projeto em suas porções de trabalho é comum desde os anos 50, quando se iniciou a decomposição da estrutura de trabalho. No entanto, a subdivisão do projeto em fases orientadas pelo tempo é relativamente recente.

Segundo Thamhain (1992), as fases podem seguir linhas funcionais, como por exemplo, conceito de design, desenvolvimento de engenharia e protótipos; ou podem ser relacionadas aos ciclos do negócio, como análise dos requisitos, propostas de compras, protótipos, produção e assim por diante; ou ainda, qualquer outra subdivisão lógica que melhor represente o conjunto de atividades estabelecidas e os resultados específicos esperados.

Cada fase do projeto é marcada pela conclusão de um ou mais produtos da fase. A conclusão de uma fase é geralmente marcada pela revisão dos principais subprodutos e pela avaliação do desempenho do projeto tendo em vista (a) determinar se o projeto deve continuar na sua próxima fase e (b) detectar e corrigir erros a um custo aceitável. O conjunto das fases de um projeto é conhecido como "ciclo de vida do projeto". 
A maioria das descrições do ciclo de vida do projeto apresentam algumas características em comum:

- O custo e a quantidade de pessoas integrantes da equipe são baixos no início do projeto, sofre incrementos no decorrer do mesmo e se reduzem drasticamente quando se aproxima de seu término. Esse modelo é ilustrado na fgura 2.2.

- No início do projeto a probabilidade de terminá-lo com sucesso é baixa e, portanto, o risco e a incerteza são altos. Normalmente esta probabilidade tende a aumentar com o decorrer do tempo.

- A capacidade das partes envolvidas de influenciar as características finais do produto e o seu custo final é alta no início e vai se reduzindo com o andamento do projeto. Isto acontece, principalmente, porque o custo de mudanças e correção de erros geralmente aumenta na medida em que o projeto se desenvolve.

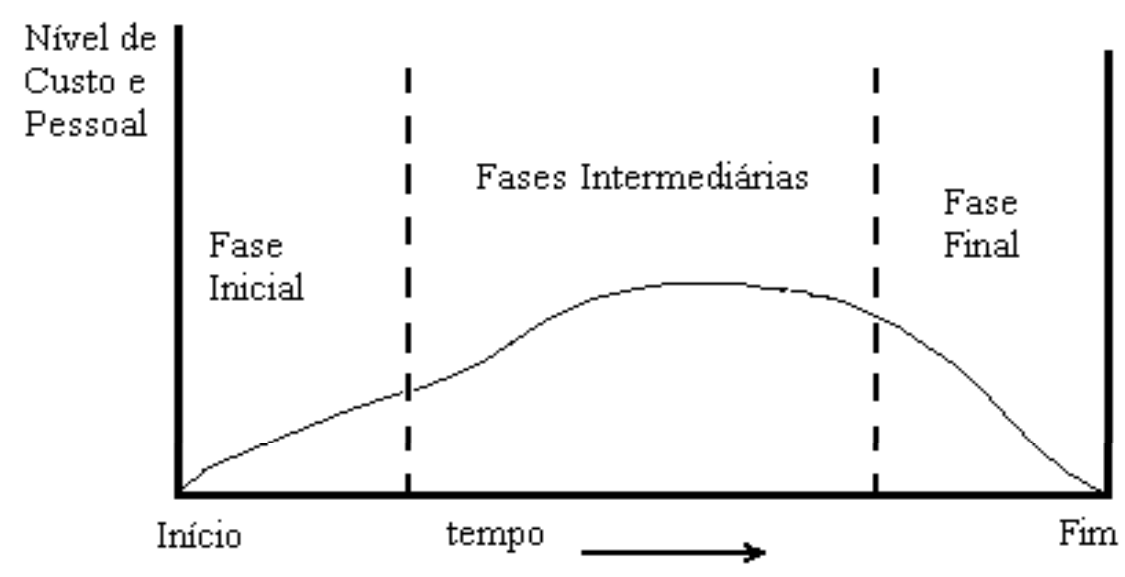

Figura 2.2 Exemplo genérico do Ciclo de Vida do Projeto (PMBOK, 2000)

Com fins ilustrativos, tomemos a divisão de um projeto e suas atividades de planejamento em seis fases:

1. Planejamento conceitual do projeto

2. Definição do projeto

3. Definição da integração e controle do projeto

4. Organização e início do projeto

5. Execução do projeto

6. Finalização do projeto 
Para os autores Thamhain (1992) e Bralla (1996), tal subdivisão representa a tipologia básica do gerenciamento de projetos e tem sido largamente aplicada pelas empresas da área técnica. A tabela 2.2 apresenta, de forma bem suscinta, as principais características de cada fase.

Thamhain (1992) cita os benefícios da divisão de projetos em fases:

- Planejamento prático e participativo

- Complexidade do programa é reduzida

- Visão global do programa

- Idéias criativas sobre a implantação

- Identificação das pessoas-chave do programa

- Envolvimento multifuncional

- Identificação dos pontos críticos

- Melhor avaliação dos resultados

- Possibilita revisões para decisões gerenciais

\begin{tabular}{|c|c|c|c|c|}
\hline Fase & Atividades principais & Resultados & Pessoas responsáveis & $\begin{array}{l}\text { Esforço } \\
\text { relativo }\end{array}$ \\
\hline $\begin{array}{l}\text { Planejamento } \\
\text { conceitual do } \\
\text { projeto }\end{array}$ & $\begin{array}{l}\text { Definir requisitos } \\
\text { Definição do programa } \\
\text { Estudo de viabilidade } \\
\text { Características do } \\
\quad \text { gerenciamento }\end{array}$ & $\begin{array}{l}\text { Objetivos globais } \\
\text { Orçamento } \\
\text { Conceito do projeto } \\
\text { Obstáculos } \\
\text { Responsabilidades }\end{array}$ & $\begin{array}{l}\text { Gerência da Eng } \\
\text { Gerência do programa }\end{array}$ & $2 \%$ \\
\hline $\begin{array}{l}\text { Definição do } \\
\text { projeto }\end{array}$ & $\begin{array}{l}\text { Detalhamento das fases do } \\
\text { programa } \\
\text { Planejamento detalhado do } \\
\text { programa } \\
\text { Revisão do plano }\end{array}$ & $\begin{array}{l}\text { Fases do programa } \\
\text { Responsabilidades } \\
\text { Objetivos do programa } \\
\text { Definir trabalho } \\
\text { Cronogramas e Verbas }\end{array}$ & $\begin{array}{l}\text { Gerência do programa } \\
\text { Lideres de grupo }\end{array}$ & $8 \%$ \\
\hline $\begin{array}{c}\text { Definição da } \\
\text { integração e } \\
\text { controle do } \\
\text { projeto }\end{array}$ & $\begin{array}{l}\text { Definição das interfaces } \\
\text { Revisões de programa } \\
\text { Autorização para iniciação } \\
\text { Definição dos medidores de } \\
\text { performance (tracking) }\end{array}$ & $\begin{array}{l}\text { Resultados da fases } \\
\text { Distribuição do trabalho } \\
\text { Integração de tarefas e } \\
\quad \text { áreas } \\
\text { Pontos de checagem }\end{array}$ & $\begin{array}{l}\text { Gerência do programa } \\
\text { Lideres de grupo }\end{array}$ & $8 \%$ \\
\hline $\begin{array}{l}\text { Organização } \\
\text { e início do } \\
\text { projeto }\end{array}$ & $\begin{array}{l}\text { Aprovação e início das } \\
\text { atividades } \\
\text { Organização dos times de } \\
\text { trabalho }\end{array}$ & $\begin{array}{l}\text { Planejamento do } \\
\text { programa } \\
\text { Alocação de recursos }\end{array}$ & $\begin{array}{l}\text { Gerência do programa } \\
\text { Lideres de grupo }\end{array}$ & $2 \%$ \\
\hline $\begin{array}{l}\text { Execução do } \\
\text { projeto }\end{array}$ & $\begin{array}{l}\text { Gerenciamento do projeto } \\
\text { Coordenação } \\
\text { Integração } \\
\text { Revisões e controles }\end{array}$ & $\begin{array}{l}\text { Relatórios do projeto } \\
\text { Propostas de alteração } \\
\text { Resultados técnicos } \\
\text { Documentação }\end{array}$ & $\begin{array}{l}\text { Gerência do programa } \\
\text { Lideres de grupo }\end{array}$ & $75 \%$ \\
\hline $\begin{array}{c}\text { Finalização } \\
\text { do projeto }\end{array}$ & $\begin{array}{l}\text { Transferência de recursos } \\
\text { Continuidade do negócio }\end{array}$ & $\begin{array}{l}\text { Dissolução do programa } \\
\text { Fechamento dos contratos }\end{array}$ & Gerência do programa & $5 \%$ \\
\hline
\end{tabular}

Tabela 2.2 Organização e gerenciamento de projetos subdivididos em fases (Thamhain, 1992). 
A idéia de analisar a manufaturabilidade do produto data da $2^{\mathrm{a}}$ Guerra Mundial, quando a escassez de recursos e a constante pressão social e política exigia a fabricação de armas melhores e nos menores prazos possíveis. Estes fatores motivaram a forte integração das atividades de desenho do produto e manufatura.

Muitas das armas de sucesso desse período foram projetadas por pequenos e integrados times multi-funcionais. No entanto, com o pós-guerra e início da prosperidade e rápido crescimento da indústria, as atividades de manufatura e desenvolvimento do produto foram segregadas, resultando em um ambiente sequencial de desenvolvimento do produto com pouca atenção a manufaturalibilidade destes durante a fase de projeto.

A crescente competição global e a necessidade de redução de lead time trouxeram a redescoberta da filosofia do "design for manufacture", no final dos anos 70. As primeiras tentativas envolveram a adoção de times interdepartamentais com representantes dos departamentos de projeto e de manufatura. No entanto, estes times nem sempre trabalhavam harmoniosamente e eram comuns os problemas gerenciais na coordenação dos mesmos.

Numa tentativa de aumentar a credibilidade das considerações de manufatura entre os projetistas, foi publicado um grande número de trabalhos, que serviam como guias, os quais os projetistas estudavam para tentar evitar aquelas configurações que resultariam em um produto pobre em manufaturabilidade.

A partir dos anos 80, a disponibilidade do poderio computacional a um relativo baixo custo oferece aos projetistas uma variedade de ferramentas de CAD que auxiliam o aumento de produtividade e redução do tempo gasto nas interações de fabricação, teste e redesign. Exemplos incluem as ferramentas para análise de elementos finitos, análises mecânicas, simulações e prototipagem rápida. Tais ferramentas são importantes fontes de pesquisa em Engenharia Simultânea, onde várias considerações do ciclo de vida do produto são endereçadas na fase inicial do projeto.

Atualmente, segundo os estudos de Duhovnik et al (2001), o desenvolvimento 
de produtos baseado na Engenharia Simultânea é estruturado na criação de times multidisciplinares, que deve incluir profissionais de vários departamentos da empresa, bem como representantes de fornecedores e clientes estratégicos.

Os membros do time devem estar conectados por uma rede que lhes permitam acessar os dados e informações dos produtos e processos disponíveis nos sistemas locais. A harmonização dos padrões de comunicação é, portanto, primordial para que essa integração ocorra.

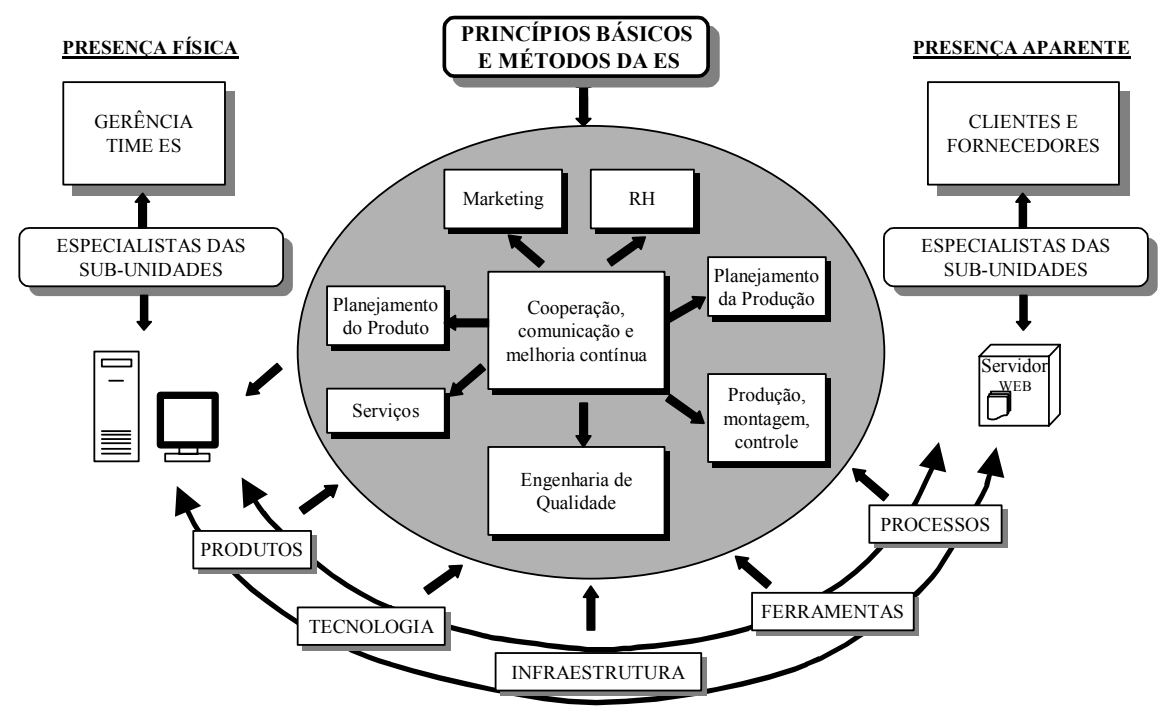

Figura 2.3 Desenvolvimento de produtos por times multidisciplinares (Duhovnik,2001).

Para Slack (1993), a aplicação da engenharia simultânea deve estabelecer a ligação entre as tecnologias de produto e processo pela construção de "pontes" entre os grupos responsáveis pelos estágios do processo de desenvolver-operacionalizar:

- Pontes procedimentais: institucionalizar formalmente procedimentos como planejamento e programação conjunta de atividades, responsabilidade conjunta pelo projeto e sistema de avaliação.

- Pontes humanas: tais como rotatividade e transferências temporárias de pessoal, encorajamento de contatos informais e criação de funções com papel de ligação entre os setores.

- Pontes organizacionais: como uma estrutura organizacional formal para gerenciar o projeto, força tarefa e gerentes de projeto. 


\subsubsection{Design for Assembly}

O Design for Assembly (DFA) surgiu na Europa durante a década de 70, juntamente com o conceito de Design for Manufacture (DFM), com o objetivo de projetar um produto visando reduzir custos, diminuindo o número de componentes e facilitando a montagem.

O Design for Assembly leva em consideração a função, a forma, o material e a montagem de cada peça, de modo a desenvolver um produto funcional e simples, minimizando e/ou incorporando peças do sistema e reduzindo o custo do produto e da montagem.

Um dos focos principais do DFA é a minimização do número de peças numa montagem, pois em função disto o custo do produto e da montagem podem ser reduzidos, graças à simplificação do produto e à redução do tempo de montagem. Segundo Bralla (1986), uma montagem deve ser usada somente quando resultados e custos desejáveis (inclusive custo de ferramental) puderem ser melhor alcançados com um agrupamento de peças do que com uma peça individual mais complexa.

De acordo com Trucks (1987), além de reduzir o número de componentes de um sistema, um efetivo DFA direciona o projeto para uma melhor habilidade das peças se unirem de maneira mais eficiente e com melhor qualidade. Boothroyd; Dewhurst; Knight (1994) complementam que a melhor maneira de minimizar os custos de montagem é considerando os tópicos abaixo:

- Promover a montagem modular.

- Padronização de componentes e produtos.

- Projetar peças com características auto-fixadoras.

- Utilizar a da lei da gravidade na montagem.

- Projetar peças com características de auto-localização.

- Possibilitar submontagens de componentes de um produto

- Projetar peças com peso reduzido e que permitam fácil manipulação.

- Projetar peças que possam se movimentar durante a montagem.

- Otimizar a seqüência de montagem. 
A figura 2.4 sumariza as típicas etapas do processo de desenvolvimento de produtos utilizando as técnicas de DFM/A, numa filosofia de engenharia simultânea.

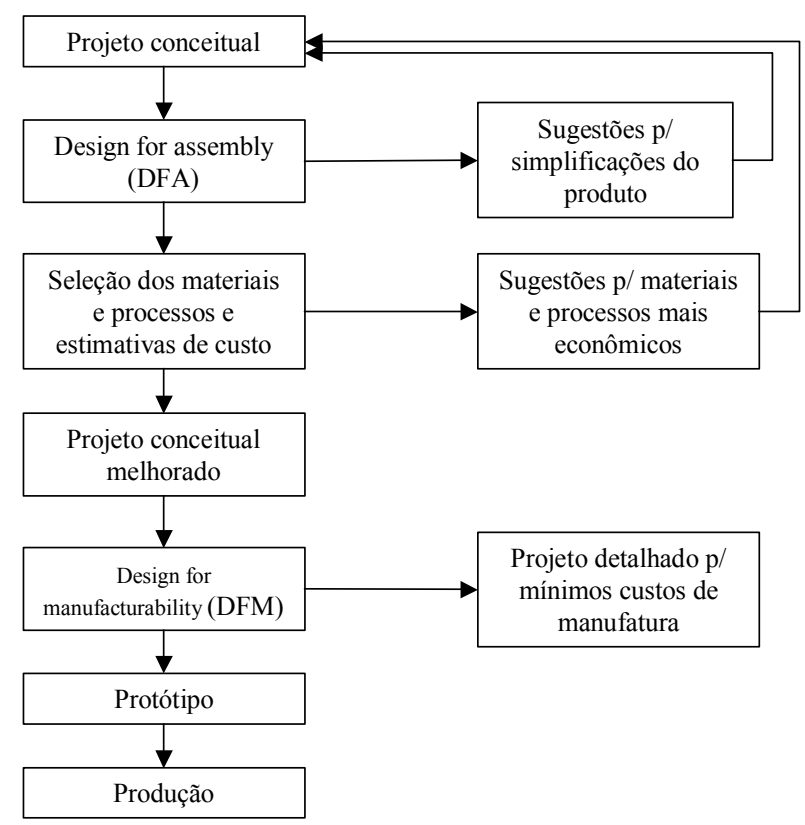

Figura 2.4 Etapas dos estudos de engenharia simultânea usando técnicas de DFM/A (Boothroyd; Dewhurst; Knight, 1994)

O sucesso na implementação do processo de desenvolvimento de produtos/processos visando a montabilidade, utilizando-se o DFA como ferramenta, depende de vários fatores (Boothroyd; Dewhurst; Knight, 1994):

- Formação de uma equipe de trabalho, com representantes de todas as áreas funcionais.

- Utilização do DFA nas etapas iniciais, principalmente no projeto conceitual, quando a tomada de decisões têm o maior efeito nos custos de um produto pelo menor investimento.

- Treinamento da equipe de trabalho para a aplicação do método DFA.

- Análise comparativa de produtos similares para auxiliar a compreensão dos conceitos e práticas em uso.

- Estimular criatividade e inovação: é o ponto de partida para melhoria da visão de um projeto básico.

- Comprometimento da gerência com a filosofia do DFA. 


\subsection{Processos de Montagem}

Nas últimas décadas, foram desenvolvidas muito mais técnicas produtivas voltadas para a fabricação dos componentes do que aplicadas à montagem. No entanto, essa situação tem mudado bastante nos últimos anos em função da competitividade, com a crescente demanda por menor conteúdo de trabalho, da exigência de aumento de produtividade e melhoria do ambiente de trabalho. Essa demanda por produtividade pode ser obtida pela adoção de novos métodos na organização e na produção, aliados à crescente mecanização e automação.

\subsubsection{Definição de Montagem}

O termo montagem pode apresentar diferentes contextos, variando de empresa para empresa, mas de uma forma mais simples, pode ser definido como o processo de junção de peças, componentes e sub-montagens, para formar um produto mais complexo (Andreasen; Kähler; Lund, 1988).

Esta junção pode ser obtida através da adição de elementos de fixação, da forma dos componentes, por enchimento de cavidades, adição de material, interferência, mudança de fase dos materiais, entre outros.

\subsubsection{Por que montar?}

Estudos mostram que a montagem é geralmente complicada e envolve altos custos, chegando a 40-60\% do tempo total de produção (Andreasen; Kähler; Lund, 1988). Assim, por que não desenhar produtos que não requeiram montagens? Isso pode ser possível para produtos mais simples, no entanto, nos casos mais avançados a montagem é necessária para atender aos diversos requisitos do projeto:

- Graus de liberdade de movimento

- Diferenciação de material

- Considerações da produção

- Diferenciação de funções

- Condições específicas da função 
- Considerações de estilo

A montagem de um produto mais complexo é resultado de várias etapas, nas quais os componentes e/ou sub-conjuntos são montados a uma estrutura base para formar o conjunto final ou produto acabado.

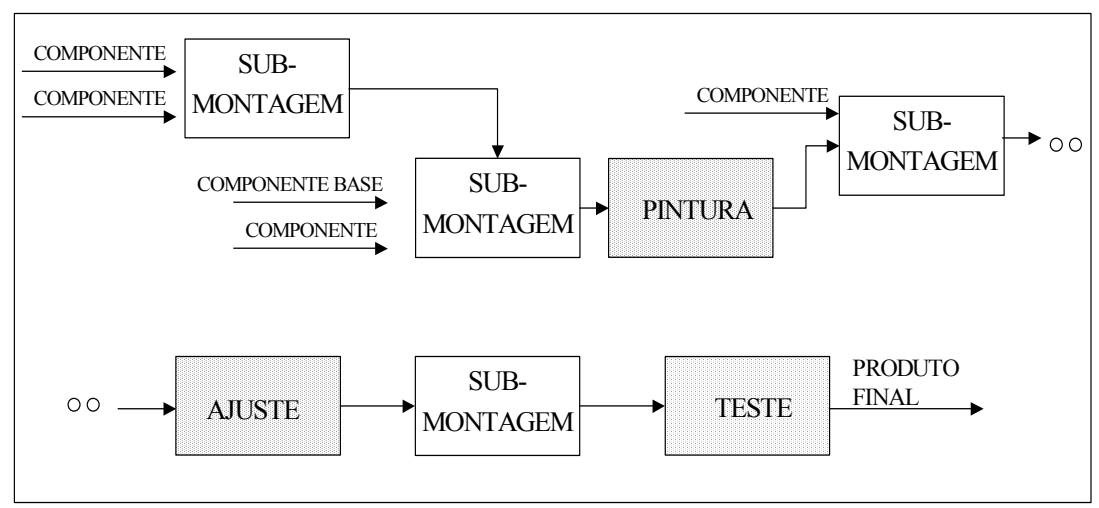

Figura 2.5 Estrutura típica de um produto montado (Andreasen; Kähler; Lund, 1988).

Conforme ilustrado na figura 2.5, o processo de montagem é conduzido pelos componentes do produto, o tipo de construção e a integração necessária com outros processos auxiliares, tais como testes, ajustes, tratamento superficial, entre outros, que podem ocorrer entre os estágios da montagem propriamente dita.

\subsubsection{Operações de montagem}

De acordo com Andreasen; Kähler; Lund (1988), o processo de montagem pode ser modelado ou descrito em função das seguintes operações:

Manusear: Processo de seleção e preparação dos componentes para montar e transportar para a próxima seqüência da produção ou montagem.

Formar: Tem por objetivo criar uma conexão relativamente permanente entre os componentes, protegendo-os da ação de fatores externos.

Checar: Processo pelo qual a presença e posição do componente é checada em adição à qualidade final do produto. Pode ocorrer de ajustes serem necessários após a checagem, com consequente "manusear" e "formar" adicionais. 
Estes três processos, por sua vez, são compostos por uma série de operações, entre as quais estão a armazenagem, o transporte e o posicionamento dos componentes ou subconjuntos. Além destes, outros processos especiais podem existir, tais como: ajuste, tratamento de superfície, embalagem, desmontagem, etc.

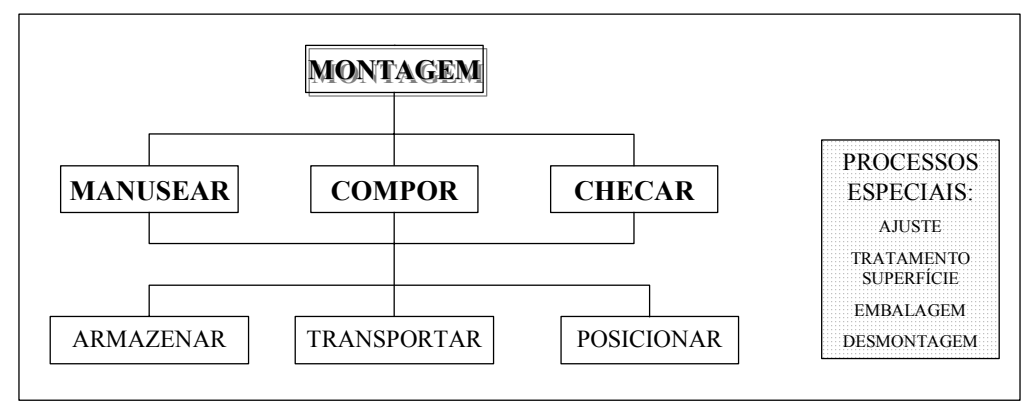

Figura 2.6 Operações do processo de montagem (Andreasen; Kähler; Lund, 1988).

\subsubsection{Equipamentos de montagem}

Numa tentativa de acelerar o processo de montagem do Ford Modelo T, Henry Ford foi o primeiro a adotar o uso de dispositivos mecanizados de transferência e a equipar o operador com ferramentas específicas de montagem, como parafusadeiras, por exemplo, resultando, na época, num processo de fabricação do Modeto T oito vezes mais rápido (Delchambre, 1992).

Atualmente estão disponíveis uma grande quantidade de equipamentos para facilitar a execução das operações de montagem descritas anteriormente, de acordo com os métodos de montagem empregados:

- Montagem manual: é o método mais versátil e pode ser executado com ou sem o auxílio de ferramentas. As ferramentas normalmente utilizadas são: apertadeiras, parafusadeiras, rebitadores, furadeiras, equipamentos para solda, dispositivos manuais, etc.

- Montagem automatizada: geralmente emprega-se transportadores automáticos, manipuladores indexados, dispositivos de transferência entre linhas ou células de montagem, etc. É utilizada nos casos em que se exige alta produtividade ou melhores condições ergonômicas para o operador. 
- Montagem robotizada: exercida por robôs, este método é o mais flexível por permitir adaptar o processo produtivo às mudanças de design apenas alterando-se a programação dos mesmos.

A escolha do equipamento deverá corresponder ao sistema de montagem implementado. É importante salientar que para se obter uma combinação perfeita do produto com o equipamento, o projetista deve considerar durante a fase de projeto do produto, o equipamento que foi definido para a operação.

\subsection{Interferências dos equipamentos de montagem}

Durante o desenvolvimento de produtos o projetista deve levar em consideração as condições de montagem requeridas pelo processo. Deve ter conhecimento dos equipamentos que serão utilizados na produção para poder prever, da melhor maneira possível, o total acesso desses equipamentos aos elementos de fixação que estão sendo definidos.

No entanto, apesar dos esforços dos projetistas em incluir esses requisitos de montagem nos projetos, através de ferramentas como o DFM/A ou a Engenharia Simultânea, é inevitável a geração de interferências entre os equipamentos de montagem e o produto.

Essas interferências a que nos referimos acontecem quando o relacionamento geométrico entre componentes e equipamentos de montagem não atende às tolerâncias especificadas. As interferências de montagem podem ser físicas ou de folga. No primeiro caso, tem-se a colisão do equipamento de montagem estabelecido para a operação com o produto. Neste caso, são exemplos de problemas de interferências: a falta de furos para acesso aos pontos de fixação, projeto não permite fixação na seqüência de montagem previamente estabelecida, espaços reduzidos entre componentes impede livre acesso do equipamento de montagem, limitações de movimentação e acesso dos manipuladores e dispositivos de montagem. 
No segundo caso, também denomina-se interferência ao não atendimento das folgas mínimas exigidas pelo processo de montagem, que deve absorver as variações dimensionais geradas durante o processo produtivo, os desgastes de ferramentas, a movimentação dos equipamentos (manuais ou automáticos), a dificuldade de acesso dos equipamentos, entre outros. 


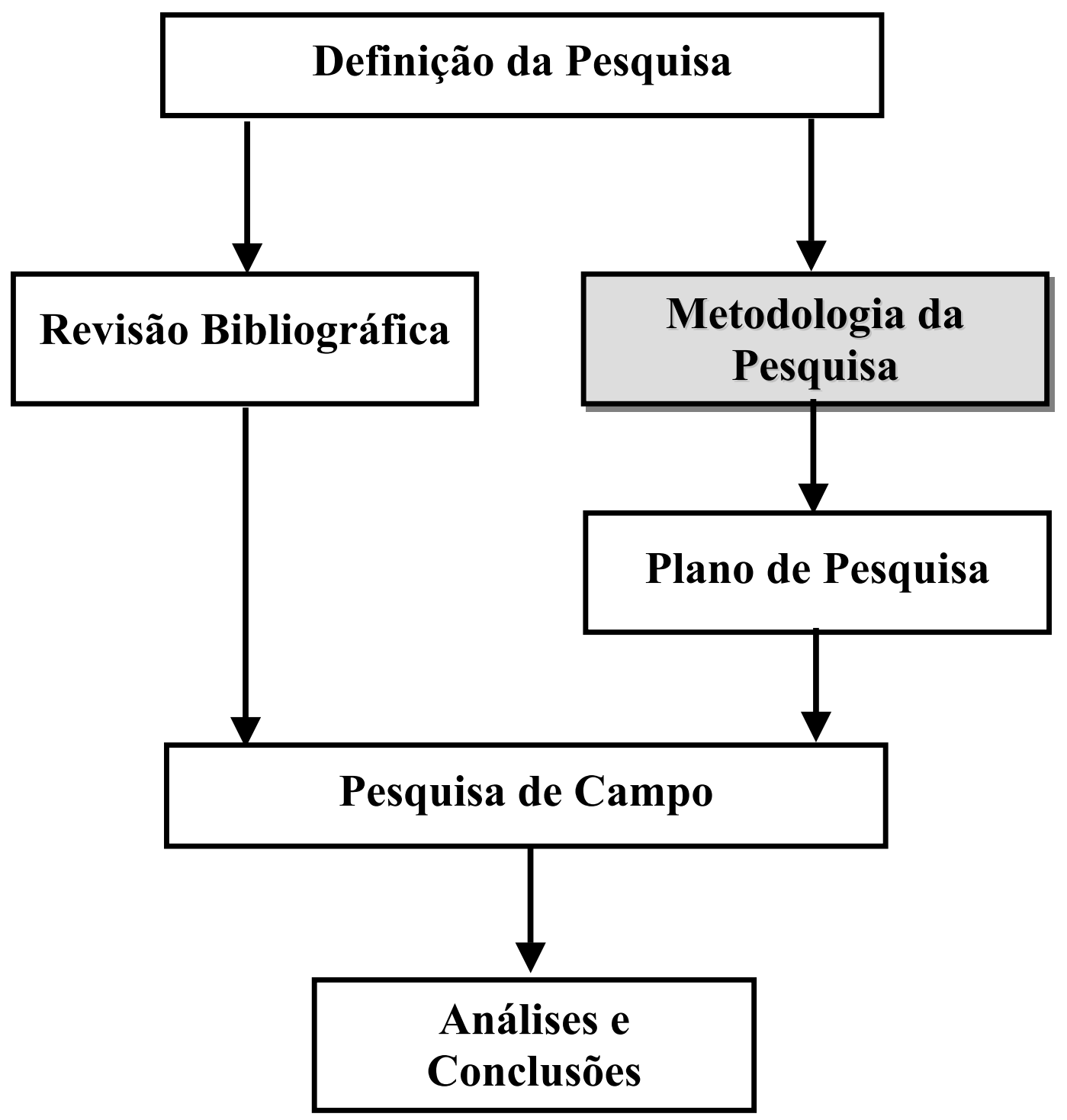




\section{CAPÍTULO 3 - METODOLOGIA DA PESQUISA}

\subsection{Introdução}

Pode-se definir pesquisa como o procedimento racional e sistemático que tem por objetivo proporcionar respostas aos problemas que são propostos. É requerida quando não se dispõe das informações suficientes para responder ao problema ou quando estas informações não estão organizadas de forma adequada (Gil, 1996).

Este capítulo tem por objetivo descrever os procedimentos e métodos científicos disponíveis para o desenvolvimento de uma pesquisa, bem como identificar o que melhor se adequa às necessidades deste trabalho.

\subsection{Abordagem da Pesquisa}

A escolha da abordagem da pesquisa é fundamental para nortear a pesquisa de forma válida e confiável e, para isto, deve estar atrelada aos objetivos centrais do estudo e à natureza do problema em questão.

Segundo Bryman (1989), duas são as abordagens para a pesquisa organizacional: abordagem quantitativa e abordagem qualitativa. A distinção entre a pesquisa quantitativa e a qualitativa não está na existência ou não de quantificação; a principal diferença da abordagem qualitativa em relação à quantitativa é a ênfase na perspectiva sobre o indivíduo estudado. A pesquisa quantitativa é impulsionada por considerações prévias da teoria e literatura, enquanto a pesquisa qualitativa evita a idéia de que o pesquisador é a fonte do que é relevante em relação ao objeto da pesquisa.

A abordagem qualitativa ressalta os seguintes pontos:

- Maior proximidade do pesquisador às circunstâncias nas quais a empresa está envolvida (abordagem perceptiva). 
- Menor rigidez na estruturação da pesquisa, proporcionando maior flexibilidade para redirecionamento (caráter exploratório).

- Seqüência dos eventos ao longo da pesquisa, diminuindo as dificuldades em reproduzir as etapas da pesquisa.

- Utilização de mais de uma fonte de dados dentro do universo da pesquisa.

A abordagem quantitativa salienta:

- Restrições iniciais sobre o alcance da pesquisa.

- A evidência de relações causais na formulação da hipótese.

- A operacionalização dos conceitos apresentados nas hipóteses.

- A inadequação de variáveis difíceis de quantificar.

- A replicação dos fenômenos estudados, de um estudo para outro.

- As conclusões que servem a generalizações, ultrapassando os limites restritos da pesquisa.

Os tipos de pergunta da pesquisa podem ser categorizados pela série: “quem", "o que", “onde”, “como" e "por que”. Segundo Yin (1994), os problemas de pesquisa do tipo "como" e "por que" estão relacionados ao caráter exploratório e mais próximos da abordagem qualitativa, enquanto questões do tipo "o que", "quem" e "onde" implicam em tratamento quantitativo visando discriminar a incidência do fenômeno estudado.

Considerando os objetivos da pesquisa e os aspectos envolvidos com as abordagens aqui descritas, conclui-se que a abordagem indicada às necessidades desta pesquisa é a abordagem qualitativa. Esta abordagem se justifica pela necessidade de envolvimento perceptivo e presença do pesquisador ao objeto de estudo e à fonte de dados, pela necessidade de confiabilidade sobre os dados e informações a serem coletados, e, também, pelo caráter exploratório da pesquisa, que pode permitir o redirecionamento da mesma no decorrer dos estudos.

\subsection{Classificação da Pesquisa}

Com base em seus objetivos gerais, segundo Gil (1996), a pesquisa pode ser classificada em exploratória, descritiva ou explicativa. 


\subsubsection{Pesquisas exploratórias}

Têm por objetivo familiarizar-se com o problema, visando torná-lo mais explícito ou estabelecer hipóteses. Pode-se dizer que estas pesquisas têm como objetivo principal o aprimoramento de idéias ou a descoberta de intuições. Seu planejamento é bastante flexível, de modo que possibilite a consideração dos mais variados aspectos relativos ao fato estudado. $\mathrm{Na}$ maioria dos casos envolvem: a) levantamento bibliográfico; b) entrevistas com pessoas que tiveram experiências práticas com o problema pesquisado e c) análise de exemplos que estimulem a compreensão.

\subsubsection{Pesquisas descritivas}

As pesquisas descritivas têm como objetivo principal a descrição das características de determinada população ou fenômeno estudado ou então, o estabelecimento de relações entre variáveis. Tem como característica marcante a utilização de técnicas padronizadas de coleta de dados, tais como o questionário e a observação sistemática.

As pesquisas descritivas geralmente assumem a forma de levantamento social, solicitadas por organizações como instituições educacionais, empresas comerciais, partidos políticos, etc.

\subsubsection{Pesquisas explicativas}

Essas pesquisas têm por objetivo identificar os fatores que determinam ou contribuem para a ocorrência dos fenômenos. Os estudos explicativos são os mais complexos por aprofundar o conhecimento da realidade, para explicar a razão, o porquê das coisas. Assim, pode-se dizer que o conhecimento científico está assentado nos resultados oferecidos pelos estudos explicativos. No entanto, isso não quer dizer que as pesquisas exploratórias e descritivas tenham menos valor, pois estas quase sempre constituem etapas prévias na obtenção das explicações científicas.

Pelo exposto acima e com base no objetivo desta pesquisa, que é descrever 
os benefícios técnicos obtidos pela adoção de ferramentas de simulação virtual dos processos de montagem em uma indústria automobilística, a pesquisa é classificada como exploratória.

\subsection{Métodos de pesquisa}

Com base nos procedimentos técnicos utilizados para a coleta de dados, os métodos de pesquisas são (Gil, 1996): pesquisa bibliográfica, pesquisa documental, pesquisa experimental, pesquisa ex-post-facto, levantamento, estudo de caso, pesquisa-ação e pesquisa participante.

\subsubsection{Pesquisa bibliográfica}

Desenvolvida a partir de material já elaborado, constitui-se principalmente de livros e artigos científicos. Boa parte dos estudos exploratórios pode ser definida como pesquisas bibliográficas. Os principais objetivos que conduzem à uma pesquisa bibliográfica são: proporcionar melhor visão do problema, obtenção de informações acerca de técnicas de coleta de dados, obtenção de dados em resposta ao problema formulado ou comparação dos resultados obtidos pelo pesquisador com aqueles fornecidos por outros estudos.

\subsubsection{Pesquisa documental}

Assemelha-se em muito à pesquisa bibliográfica, diferenciando-se apenas na natureza das fontes: enquanto a pesquisa bibliográfica se utiliza da contribuição dos diversos autores, a pesquisa documental apóia-se em materiais que ainda não receberam tratamento analítico. Os objetivos da pesquisa documental são geralmente mais específicos, visam a obtenção de dados em resposta a determinados problemas, e, não raro, envolvem o teste de hipóteses.

\subsubsection{Pesquisa experimental}

De um modo geral, o experimento representa o melhor exemplo de pesquisa científica. Essencialmente, consiste em determinar um objeto de estudo, selecionar as 
variáveis que seriam capazes de influenciá-lo, definir as formas de controle e de observação dos efeitos que a variável produz no objeto. Experimentos físicos não apresentam grandes limitações quanto à possibilidade de experimentação. No entanto, considerações éticas e humanas impedem que a experimentação se faça eficientemente nas ciências humanas.

\subsubsection{Pesquisa ex-post-facto}

Tem-se um "experimento" onde o pesquisador não tem controle sobre as variáveis, que se realizam depois dos fatos. Neste tipo de pesquisa, situações que se desenvolveram naturalmente são tomadas como experimentais e trabalha-se sobre elas como se estivessem submetidas a controle.

\subsubsection{Levantamento}

Caracteriza-se pela interrogação direta das pessoas, através de questionários auto-aplicáveis ou de entrevistas estruturadas, com o objetivo de levantar informações gerais acerca das populações. Mediante procedimentos estatísticos, seleciona-se uma amostra significativa do universo, que é tomada como objeto de investigação. As conclusões obtidas a partir desta amostra são projetadas para a totalidade do universo, levando em consideração a margem de erro, que é obtida mediante cálculos estatísticos. Este método é indicado para estudos descritivos.

\subsubsection{Estudo de caso}

O estudo de caso é caracterizado pelo estudo profundo e exaustivo de um ou de poucos objetos, de maneira que permita o seu amplo e detalhado conhecimento, tarefa praticamente impossível mediante os outros delineamentos considerados.

Sua vantagem consiste em estimular novas descobertas, em função da flexibilidade do seu planejamento, o pesquisador mantém-se atento às novas descobertas. Estas descobertas, muitas vezes, tornam-se mais relevantes que a solução do problema inicial, razão pela qual o método é recomendado para estudos exploratórios. A simplicidade dos procedimentos de coleta de dados no estudo de 
caso é outra vantagem quando comparado a outros delineamentos aqui citados. Como desvantagem, oferece dificuldade na generalização dos resultados obtidos. Pode ocorrer que a unidade escolhida para investigação seja bastante anormal em relação às muitas de sua espécie e que, naturalmente, os resultados de pesquisa sejam equivocados. Por essa razão, o estudo de caso pode requerer alto grau de capacitação do pesquisador para a análise dos resultados.

\subsubsection{Pesquisa-ação}

Envolve a ação dos pesquisadores e dos grupos interessados na resolução de um problema coletivo, de modo cooperativo ou participativo. Na pesquisa-ação ocorre um constante vaivém entre as fases, que é determinado pela dinâmica do grupo de pesquisadores em seu relacionamento com a situação pesquisada, dificultando o planejamento ordenado no tempo. Apesar deste tipo de pesquisa ser alvo de muitas controvérsias, por exigir o envolvimento ativo do pesquisador e das pessoas envolvidas no problema, vem sendo reconhecido como útil por pesquisadores envolvidos com ideologias reformistas.

\subsubsection{Pesquisa participante}

A pesquisa participante e a pesquisa-ação são tidas por alguns autores como sinônimos. Todavia, a pesquisa-ação supõe uma forma de ação planejada, de caráter social, educacional ou técnico, enquanto a pesquisa participante envolve a distinção entre ciência popular e ciência dominante, considera posições valorativas, derivadas do humanismo cristão e de certas concepções marxistas. Além disto, está comprometida com a minimização da relação entre dirigentes e dirigidos.

O estudo de caso é o método que melhor se enquadra aos objetivos deste trabalho pois, conforme mencionado anteriormente, é o método recomendado para estudos exploratórios; graças a sua flexibilidade de planejamento, permite estimular novas descobertas e a simplicidade nos procedimentos de coletas de dados é um fator relevante neste estudo, que trata de simulações, um assunto relativamente pouco explorado. 


\subsection{Resumo da metodologia de pesquisa}

Analisando-se os conceitos e as considerações anteriormente descritos sobre a metodologia de pesquisa, conclui-se que esta pesquisa deve receber uma abordagem qualitativa, é classificada como exploratória e o estudo de caso é o método mais adequado aos objetivos deste trabalho.

\begin{tabular}{|l|c|c|c|c|c|c|c|c|}
\hline $\begin{array}{l}\text { Requisitos da } \\
\text { pesquisa }\end{array}$ & $\begin{array}{l}\text { Pesquisa } \\
\text { Bibliográ- } \\
\text { fica }\end{array}$ & $\begin{array}{l}\text { Pesquisa } \\
\text { Documen- } \\
\text { tal }\end{array}$ & $\begin{array}{l}\text { Pesquisa } \\
\text { Experime } \\
\text { ntal }\end{array}$ & $\begin{array}{l}\text { Pesquisa } \\
\text { ex-post- } \\
\text { facto }\end{array}$ & $\begin{array}{l}\text { Levanta- } \\
\text { mento }\end{array}$ & $\begin{array}{l}\text { Estudo } \\
\text { de Caso }\end{array}$ & $\begin{array}{l}\text { Pesquisa- } \\
\text { ação }\end{array}$ & $\begin{array}{l}\text { Pesquisa } \\
\text { Partici- } \\
\text { pante }\end{array}$ \\
\hline $\begin{array}{l}\text { Análise de alguns } \\
\text { objetos }\end{array}$ & Difícil & Difícil & Difícil & $\begin{array}{c}\text { Não } \\
\text { aplicável }\end{array}$ & $\begin{array}{c}\text { Não } \\
\text { adequado }\end{array}$ & Adequado & $\begin{array}{c}\text { Não } \\
\text { adequado }\end{array}$ & $\begin{array}{c}\text { Não } \\
\text { adequado }\end{array}$ \\
\hline $\begin{array}{l}\text { Possibilidade de } \\
\text { responder à } \\
\text { pergunta "como" }\end{array}$ & Impossível & Difícil & Difícil & $\begin{array}{c}\text { Não } \\
\text { adequado }\end{array}$ & Difícil & Adequado & $\begin{array}{c}\text { Não } \\
\text { adequado }\end{array}$ & $\begin{array}{c}\text { Não } \\
\text { adequado }\end{array}$ \\
\hline $\begin{array}{l}\text { Entrevista direta } \\
\text { com os } \\
\text { envolvidos }\end{array}$ & Impossível & Impossível & Possível & $\begin{array}{c}\text { Não } \\
\text { adequado }\end{array}$ & Difícil & Adequado & $\begin{array}{c}\text { Não } \\
\text { adequado }\end{array}$ & $\begin{array}{c}\text { Não } \\
\text { adequado }\end{array}$ \\
\hline $\begin{array}{l}\text { Compreensão } \\
\text { profunda sobre } \\
\text { simulações }\end{array}$ & Impossível & Impossível & Difícil & $\begin{array}{c}\text { Não } \\
\text { adequado }\end{array}$ & Difícil & Adequado & $\begin{array}{c}\text { Não } \\
\text { adequado }\end{array}$ & $\begin{array}{c}\text { Não } \\
\text { adequado }\end{array}$ \\
\hline $\begin{array}{l}\text { Fronteiras não pré } \\
\text { definidas }\end{array}$ & Difícil & Difícil & $\begin{array}{c}\text { Não } \\
\text { adequado }\end{array}$ & $\begin{array}{c}\text { Não } \\
\text { adequado }\end{array}$ & Difícil & Adequado & $\begin{array}{c}\text { Não } \\
\text { adequado }\end{array}$ & $\begin{array}{c}\text { Não } \\
\text { adequado }\end{array}$ \\
\hline $\begin{array}{l}\text { Limitações de } \\
\text { tempo }\end{array}$ & Difícil & Difícil & Difícil & $\begin{array}{c}\text { Não } \\
\text { adequado }\end{array}$ & Possível & Possível & $\begin{array}{c}\text { Não } \\
\text { adequado }\end{array}$ & $\begin{array}{c}\text { Não } \\
\text { adequado }\end{array}$ \\
\hline $\begin{array}{l}\text { Presença do } \\
\text { pesquisador na } \\
\text { coleta de dados }\end{array}$ & $\begin{array}{l}\text { Não } \\
\text { adequado }\end{array}$ & Nadequado & Possível & $\begin{array}{c}\text { Não } \\
\text { adequado }\end{array}$ & Adequado & Adequado & Adequado & Adequado \\
\hline
\end{tabular}

Tabela 3.1 Quadro resumo do processo de escolha do método de pesquisa

\begin{tabular}{|c|c|}
\hline \multicolumn{2}{|c|}{ Metodologia } \\
\hline Abordagem & Qualitativa \\
\hline Tipo de Pesquisa & Exploratória \\
\hline Método de Pesquisa & Estudo de Caso \\
\hline
\end{tabular}

Tabela 3.2 Quadro resumo da metodologia 


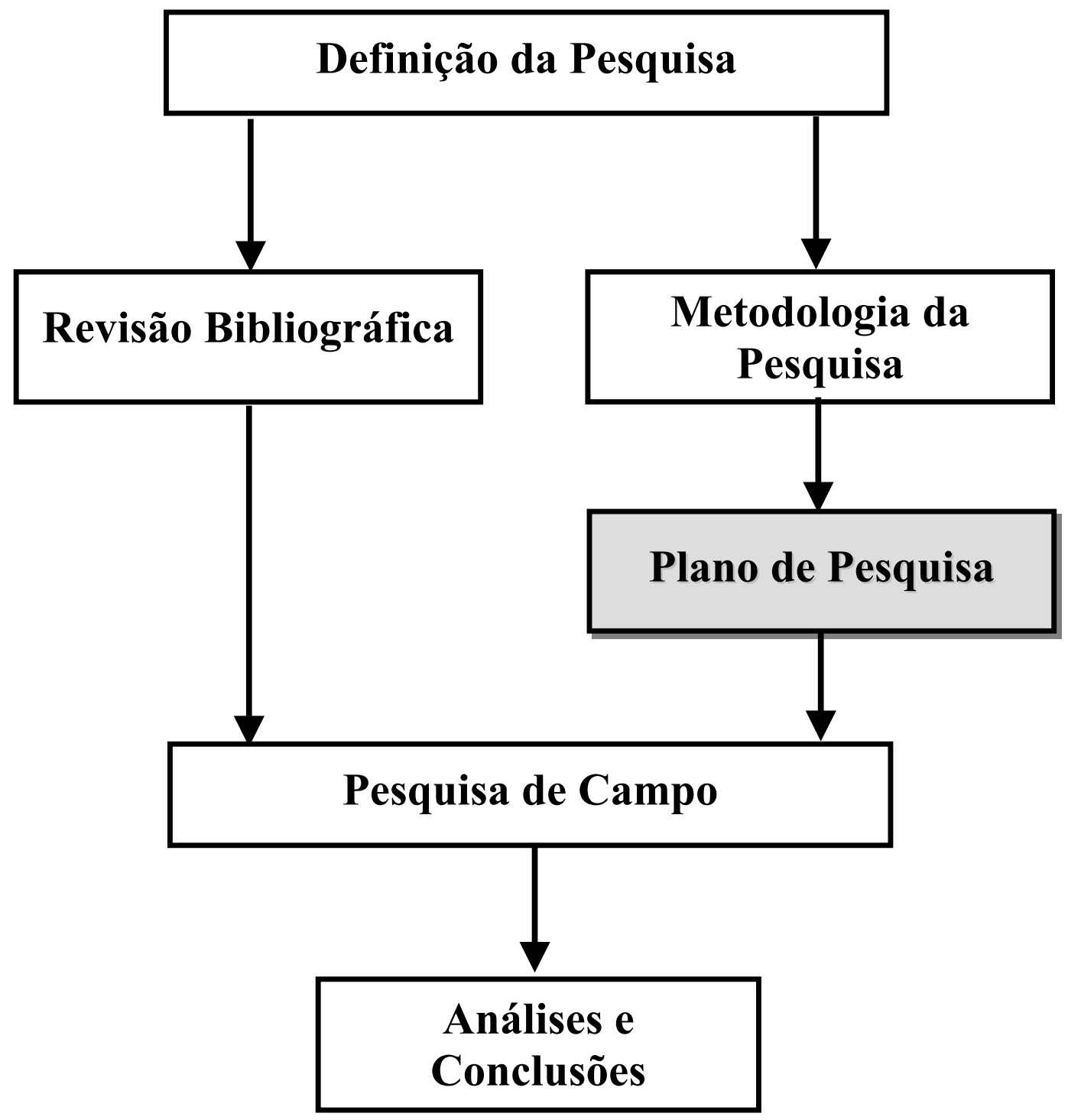




\section{CAPÍTULO 4 - PLANO DE PESQUISA}

\subsection{Introdução}

Plano de pesquisa é uma seqüência que liga os dados empíricos aos problemas iniciais da pesquisa e às suas conclusões. Um plano de pesquisa é um plano de ação para se ir de um conjunto de perguntas a serem respondidas ao conjunto de conclusões, às respostas a estas questões.

Os autores Yin (1994) e Gil (1996) propõem a necessidade de que o plano de ação contenha uma estrutura lógica que permita atingir os objetivos do estudo de caso e validar suas conclusões. Para facilitar o acompanhamento das ações correspondentes a cada uma das etapas do plano de pesquisa, é usual a apresentação dessa estrutura sob a forma de diagrama, conforme a figura 4.1 .

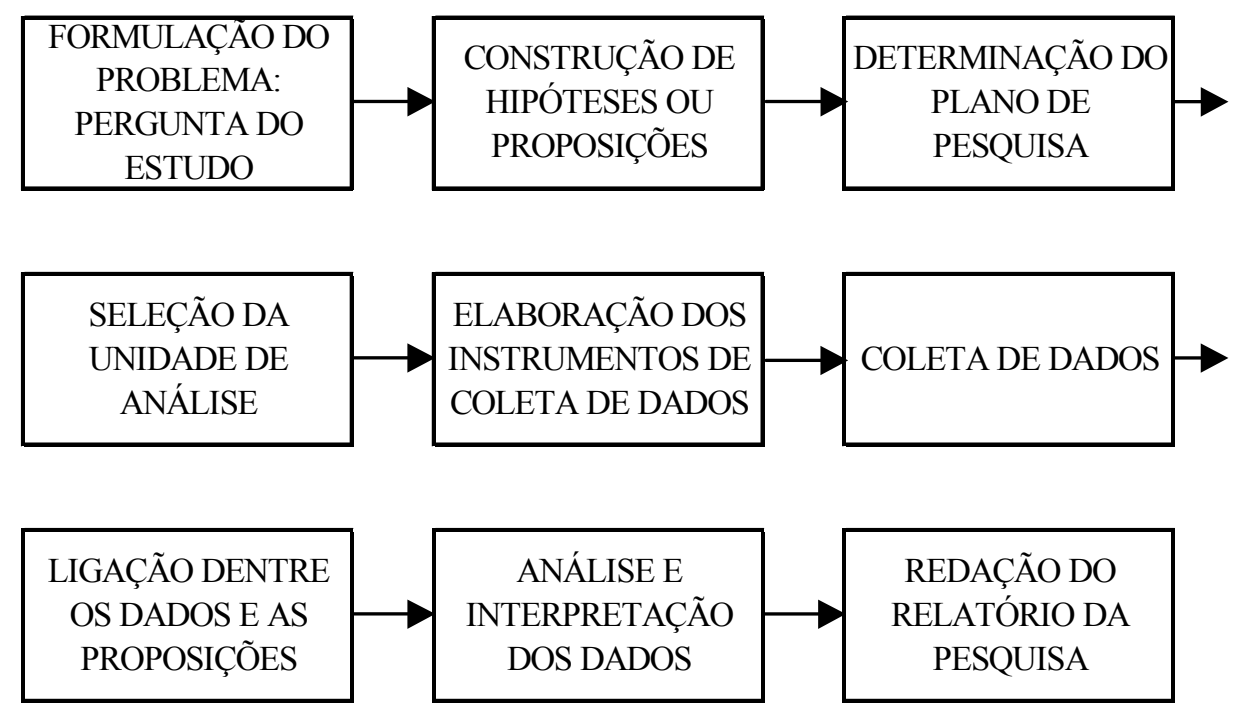

Figura 4.1 Diagramação da pesquisa.

As perguntas do estudo: envolvem quais questões serão estudadas, quais os dados relevantes, quais dados serão levantados e como analisar os resultados.

As proposições: devem nortear o pesquisador dentro do escopo do estudo. 
Unidade de análise: é a unidade central do problema de pesquisa, podendo ser uma empresa, uma área específica, uma atividade, um processo, etc.

Ligação lógica entre os dados e as proposições: é o aspecto mais importante do projeto de pesquisa, uma vez que vai determinar a validade do estudo.

Interpretação dos dados coletados: deve ser o objeto de análise crítica por parte do pesquisador, considerando nesta análise as limitações da abordagem analítica, evitando a falsa certeza sobre as próprias conclusões.

$\mathrm{O}$ quadro abaixo apresenta a estrutura do planejamento da pesquisa e as ações a serem tomadas:

Tabela 4.1 Estrutura do planejamento da pesquisa

\begin{tabular}{|c|c|}
\hline Pergunta & $\begin{array}{l}\text { Como as áreas de projetos e processos de empresas fabricantes } \\
\text { de veículos automotivos podem se beneficiar dos softwares } \\
\text { simuladores de montagem, durante as fases de projeto do } \\
\text { produto e especificações dos processos a serem utilizados? }\end{array}$ \\
\hline Unidade de Análise & $\begin{array}{l}\text { Departamento de Engenharia de Processos de Montagem de } \\
\text { Veículos da General Motors do Brasil }\end{array}$ \\
\hline Proposições & $\begin{array}{l}\mathbf{H}_{1} \text { : "O crescimento da aplicação de simulações virtuais em } \\
\text { projetos de veículos contribui para a redução de custos } \\
\text { adicionais em equipamentos de montagem, novos ou } \\
\text { retrabalhos de existentes". } \\
\mathbf{H}_{2} \text { : "O crescimento da aplicação de simulações virtuais em } \\
\text { projetos de veículos aumenta a detecção de interferências } \\
\text { dimensionais entre partes e equipamentos numa montagem, } \\
\text { durante a fase de projeto". }\end{array}$ \\
\hline Dados Relevantes & $\begin{array}{l}\text { - Avaliação dos custos ocasionados pela detecção tardia de } \\
\text { interferências de montagem } \\
\text { - Avaliação dos custos evitados com a aplicação das } \\
\text { simulações virtuais dos processos de montagem }\end{array}$ \\
\hline
\end{tabular}


Tabela 4.1. Estrutura do planejamento da pesquisa (continuação).

\begin{tabular}{|c|c|}
\hline $\begin{array}{c}\text { Dados Relevantes } \\
\text { (continuação) }\end{array}$ & $\begin{array}{l}\text { - Análise da detecção de interferências na fase de projeto } \\
\text { - Flexibilidade para modificações de peças do projeto em } \\
\text { função do budget e timing } \\
\text { - Análise da montabilidade dos produtos }\end{array}$ \\
\hline $\begin{array}{l}\text { Ligação Lógica } \\
\text { entre os Dados e as } \\
\text { Proposições }\end{array}$ & $\begin{array}{l}\text { H: Redução de custos adicionais em equipamentos de } \\
\text { montagem, novos ou retrabalhos de existentes. } \\
\text { - Avaliação dos custos ocasionados pela detecção tardia de } \\
\text { interferências de montagem } \\
\text { - Avaliação dos custos evitados com a aplicação das } \\
\text { simulações virtuais dos processos de montagem } \\
\text { - Análise da montabilidade dos produtos } \\
\text { H2: Aumento da detecção de interferências dimensionais entre } \\
\text { partes e equipamentos numa montagem, durante a fase de } \\
\text { projeto. } \\
\text { - Análise das possibilidades de detecção de interferências na } \\
\text { fase de projeto } \\
\text { - Análise da montabilidade } \\
\text { Flexibilidade para modificações de peças do projeto em } \\
\text { função do budget e timing }\end{array}$ \\
\hline $\begin{array}{l}\text { Critério de } \\
\text { interpretação dos } \\
\text { dados encontrados }\end{array}$ & $\begin{array}{l}\text { A partir das informações dos projetos em estudo, dos custos } \\
\text { ocasionados pela detecção tardia de interferências ou dos custos } \\
\text { evitados com a aplicação das simulações virtuais dos processos } \\
\text { de montagem, é possível avaliar a contribuição das simulações } \\
\text { virtuais para a redução de custos adicionais em equipamentos } \\
\text { de montagem. } \\
\text { Analisando-se as possibilidades de detecção de interferências } \\
\text { na fase de projeto e as condições de montagem do produto, é } \\
\text { possível revelar a contribuição das simulações virtuais para o } \\
\text { aumento da detecção de interferências dimensionais entre } \\
\text { partes e equipamentos numa montagem. }\end{array}$ \\
\hline
\end{tabular}




\subsection{Elaboração da Pesquisa}

Como já foi mencionado, o estudo de caso caracteriza-se por grande flexibilidade, sendo impossível o estabelecimento de um roteiro rígido para o desenvolvimento da pesquisa. Todavia, algumas etapas são fundamentais no delineamento de um estudo de caso (Gil, 1996):

- Planejamento da pesquisa

- Delimitação da unidade-caso

- Coleta de dados

- Análise e interpretação dos dados

- Redação do relatório

Com relação ao planejamento da pesquisa, este foi estruturado conforme quadro da tabela 4.1. As demais etapas serão descritas e detalhadas nos tópicos subsequentes.

\subsection{Delimitação da Unidade-caso}

Cada vez mais a General Motors do Brasil tem buscado a especialização no desenvolvimento de novos produtos e novas plataformas. Mais intensamente nos últimos cinco anos a área de Manufatura tem sido acionada no sentido de buscar uma solução conjunta aos problemas surgidos durante um projeto.

No entanto, certas questões relacionadas à montagem do produto são difíceis de serem respondidas na fase de projeto apenas analisando-se desenhos ou seções ou imagens do CAD. Mais que isso, torna-se necessário aguardar que a proposta seja representada fisicamente no produto para que se valide, ou não, a solução.

O problema é que esse tempo perdido pode resultar na impossibilidade (custo, timing) de modificação do produto para atender às necessidades de Manufatura. Dessa forma, a Manufatura acaba tendo de buscar alternativas, muitas vezes improdutivas, para se adequar ao produto. 
Neste sentido, a recente introdução de softwares simuladores como ferramenta de visualização e validação do processo de montagem durante a concepção do produto e, posteriormente, na implementação de melhorias ao produto ou ao processo produtivo apresenta-se como uma ferramenta nova e bastante atraente ao Departamento de Engenharia de Processos de Montagem de Veículos, motivo pelo qual este tema foi escolhido para esse trabalho.

\subsection{Instrumento de coleta de dados}

A coleta de dados pode ser feita a partir de observações, análise de documentos, questionários, entrevistas e formulários. O questionário é uma forma organizada de se obter e registrar informações específicas e relevantes com exatidão e abrangência necessária. De acordo com Green; Tull; Albaur (1988), a comunicação por meio de questionários não está limitada a entrevistas pessoais, pois o instrumento pode ser aplicado também em entrevistas por telefone, enviadas pelo correio ou via internet (e-mail).

O instrumento de coleta de dados utilizado nessa pesquisa foi um questionário semi-estruturado elaborado para ser aplicado na forma de um roteiro para pesquisa de campo, através de entrevistas semi-estruturadas a serem conduzidas e aplicadas pelo pesquisador, pessoalmente ou por telefone. Em todos os casos os entrevistados receberam uma breve explanação dos objetivos da pesquisa e o que se esperava obter de informações das áreas analisadas. Esse questionário-roteiro objetiva, basicamente:

- Garantir uma linha de exploração homogênea com todos os entrevistados.

- Direcionar e focar o processo de obtenção de dados relevantes ao tema pesquisado.

- Facilitar o registro e análise das informações e dos dados coletados.

Para a elaboração do instrumento de pesquisa, a linha de raciocínio a ser explorada deve estar relacionada com elementos que permitam captar dados e informações que possibilitem responder à pergunta: Como as áreas de projetos e 
processos de empresas fabricantes de veículos automotivos podem se beneficiar dos softwares simuladores de montagem, durante as fases de projeto do produto e especificações dos processos a serem utilizados? Deve-se ainda colher subsídios que permitam testar as proposições anteriormente estabelecidas. Dessa foram, os objetivos específicos a serem explorados são:

- Avaliar as implicações de se detectar interferências de montagem somente após a fabricação de protótipos físicos.

- Identificar as contribuições do uso de simulações virtuais de montagem.

- Identificar o momento mais adequado para uso das simulações.

- Analisar a detecção de interferências dimensionais entre partes e equipamentos de montagem na fase de projeto.

- Analisar as dificuldades e limitações do uso das simulações virtuais.

Com a finalidade de organizar as informações a serem exploradas junto às pessoas a serem entrevistadas, dividimos o questionário em três seções, descritas a seguir:

\section{a) Caracterização do departamento ou setor}

Nesta seção do questionário, procura-se obter informações básicas a fim de que se possa identificar a estrutura organizacional dos departamentos ou setores para os projetos em análise, as atividades por estes desenvolvidas e o número de funcionários da área. Busca-se também captar dados que relacionem a área ao uso de simulações virtuais de montagem.

\section{b) Caracterização geral dos projetos}

Procura-se identificar nesta seção do questionário os elementos que diferem um projeto do outro e suas implicações no estabelecimento dos processos de montagem. Os projetos são avaliados quanto aos recursos tecnológicos empregados, onde se busca identificar aqueles que tiveram seu uso aprimorado ou surgiram recentemente na empresa ou no mercado. 


\section{c) Caracterização dos estudos de caso}

O que se pretende nessa seção do questionário é a obtenção de dados que nos forneça subsídios para podermos comparar a detecção de interferências de montagem no Projeto A16, quando não tivemos o uso de simulações virtuais na Manufatura, com a detecção de interferências dimensionais entre partes e equipamentos de montagem no Projeto A03, quando as condições de montagem foram avaliadas através das simulações virtuais durante o desenvolvimento do produto.

Além da obtenção de dados dentro da Engenharia de Processos de Montagem de Veículos, onde a pesquisa está centralizada, também serão colhidas informações sobre o uso de simulações virtuais do ponto de vista de pessoas de outros departamentos que também estão envolvidos com o novo processo de desenvolvimento virtual dos produtos, os quais passam a depender dessa ferramenta para a análise do produto e dos processos produtivos determinados para a montagem do mesmo. Nestes casos, somente algumas questões específicas serão aplicadas.

\subsection{Pré-teste do questionário-roteiro}

Objetivando a avaliação e validação do questionário-roteiro, foi efetuado um pré-teste prático de aplicação do instrumento de pesquisa. Procurou-se neste processo não dirigir a atenção ao conteúdo dos objetivos principais da pesquisa, mas sim verificar se o questionário-roteiro conseguiria garantir a apuração daquilo que se pretendia pesquisar. Para a realização das entrevistas, foram escolhidas duas pessoas da Engenharia de Processos e que atuam em áreas diferentes da especificação dos processos de montagem de veículos. As entrevistas foram agendadas para serem realizadas separadamente, buscando assim obter opiniões diferenciadas de ambos os entrevistados.

Após uma explanação geral sobre os objetivos do trabalho e especificamente sobre o objetivo deste primeiro contato, ou seja, o teste do roteiro de pesquisa, foram-lhes entregues uma cópia do questionário para facilitar o acompanhamento da entrevista e possibilitar que os entrevistados também fizessem 
anotações a respeito do roteiro em suas mãos. Um dos colaboradores já estava familiarizado com a aplicação de simulações virtuais para detecção de interfências entre partes e equipamentos de montagem, enquanto que para o outro, tratava-se de um assunto relativamente novo. Todas as perguntas que necessitaram explicações adicionais, ou aquelas em que se verificou não estarem claras para os entrevistados, foram identificadas para serem melhoradas na revisão final do roteiro.

Após o término das entrevistas e preenchimento dos questionários, foi solicitado aos entrevistados que comentassem sobre as dificuldades na interpretação das perguntas, as dificuldades para as respostas e quais eram suas sugestões de melhoria do instrumento de pesquisa.

O pré-teste do questionário-roteiro revelou que algumas perguntas não estavam suficientemente claras ou focadas especificamente nas informações necessárias ao teste das proposições anteriormente estabelecidas. $\mathrm{Na}$ análise dos dados levantados, verificou-se a obtenção de dados que não eram relevantes à pesquisa, enquanto outros, mais importantes, estavam dispersos e não revelavam toda a essência da questão. Em conseqüência, o questionário foi reformulado: foram feitas alterações na estrutura do mesmo, algumas questões foram removidas, enquanto outras foram adicionadas ou reformuladas, visando basicamente conseguir maior objetividade nas respostas e facilitar a análise dos dados.

O roteiro reformulado ficou composto por três seções: caracterização do departamento ou setor, caracterização geral dos projetos e caracterização dos estudos de caso. Este roteiro está contido no Anexo A.

\subsection{Seleção dos casos}

Embora existam vários projetos em andamento dentro da GMB, é importante a seleção daqueles que nos permita extrair os casos que possuem melhor qualidade e exatidão de informações.

Dessa forma, a idéia inicial de se avaliar o projeto de duas pick-ups pequenas, ambas derivativas de veículos de passageiros, não pode ser levada adiante 
devido às dificuldades de obtenção dos dados relacionados ao projeto anterior, desenvolvido há quase dez anos. Também foi analisado o fato de que apesar das características físicas serem semelhantes, o mercado consumidor exigiu novos requisitos, que só puderam ser atendidos com o surgimento de novas tecnologias de projeto, muito diferentes das existentes naquela época.

Assim, optou-se pela análise de dois projetos mais recentes e que possuem uma base de dados mais consolidada que nos permite encontrar os dados necessários ao desenvolvimento desta pesquisa. Embora sejam de características distintas fisicamente, representam muito bem a proposta desta pesquisa por se tratar de um tema onde praticamente todos os projetos são trabalhados semelhantemente dentro da Engenharia de Processos de Montagem de Veículos.

Portanto, os projetos a que iremos nos referir neste estudo são o de um veículo de passeio desenvolvido a partir de 1998 e atualmente em início de produção, onde realizaremos o Estudo de Caso A, e o de uma pick-up pequena que se encontra em fase de projeto, sobre o qual iremos desenvolver o Estudo de Caso B.

\subsubsection{Estudo de Caso A: análise do não-uso de simulações no Projeto A16}

Neste estudo iremos avaliar as implicações resultantes da detecção de interferências dimensionais entre partes e os equipamentos de montagem apenas durante a montagem dos protótipos físicos, quando os desenhos já estão liberados para a fabricação das peças e componentes. Neste caso, busca-se avaliar quais os fatores relevantes na decisão da solução a ser tomada para resolver o problema.

\subsubsection{Estudo de Caso B: análise do uso de simulações no Projeto A03}

Neste estudo de caso temos a avaliação dos benefícios esperados das simulações virtuais quando aplicadas para a detecção de interferências dimensionais entre partes e equipamentos de montagem durante o desenvolvimento do produto. $\mathrm{E}$ quando são detectadas tais interferências, quais fatores são considerados na determinação da solução final. 
Procura-se avaliar também as dificuldades encontradas pelos usuários no trabalho com as simulações virtuais e colher sugestões do que poderia ser melhorado nesse processo de simulações.

\subsection{Coleta e verificação dos dados}

A coleta de dados será executada através de entrevistas, aplicando-se o questionário-roteiro diretamente aos Engenheiros de Processos de Montagem usuários do processo de simulação virtual e aos supervisores e gerentes da área, que possuem uma visão mais abrangente da proposta de utilização das tecnologia de simulação dentro da empresa. Além destas pessoas, outros usuários de simulações virtuais das Engenharias de Produto, da Engenharia de Processos de Armação de Carrocerias e Engenharia de Processos de Estampados serão questionados em perguntas específicas sobre o assunto.

\subsection{Análise e interpretação dos dados}

A análise dos dados é fundamental para a pesquisa, uma vez que é através dela que podemos entender como as empresas fabricantes de veículos automotivos podem se beneficiar do uso dos softwares de simulação virtual para análise dos processos de montagem durante as fases de projeto do produto.

A interpretação dos dados envolverá uma análise crítica comparativa entre os dois estudos de caso, objetivando a identificação dos fatores que diferenciam o desenvolvimento de novos produtos antes e após o uso das simulações virtuais. 


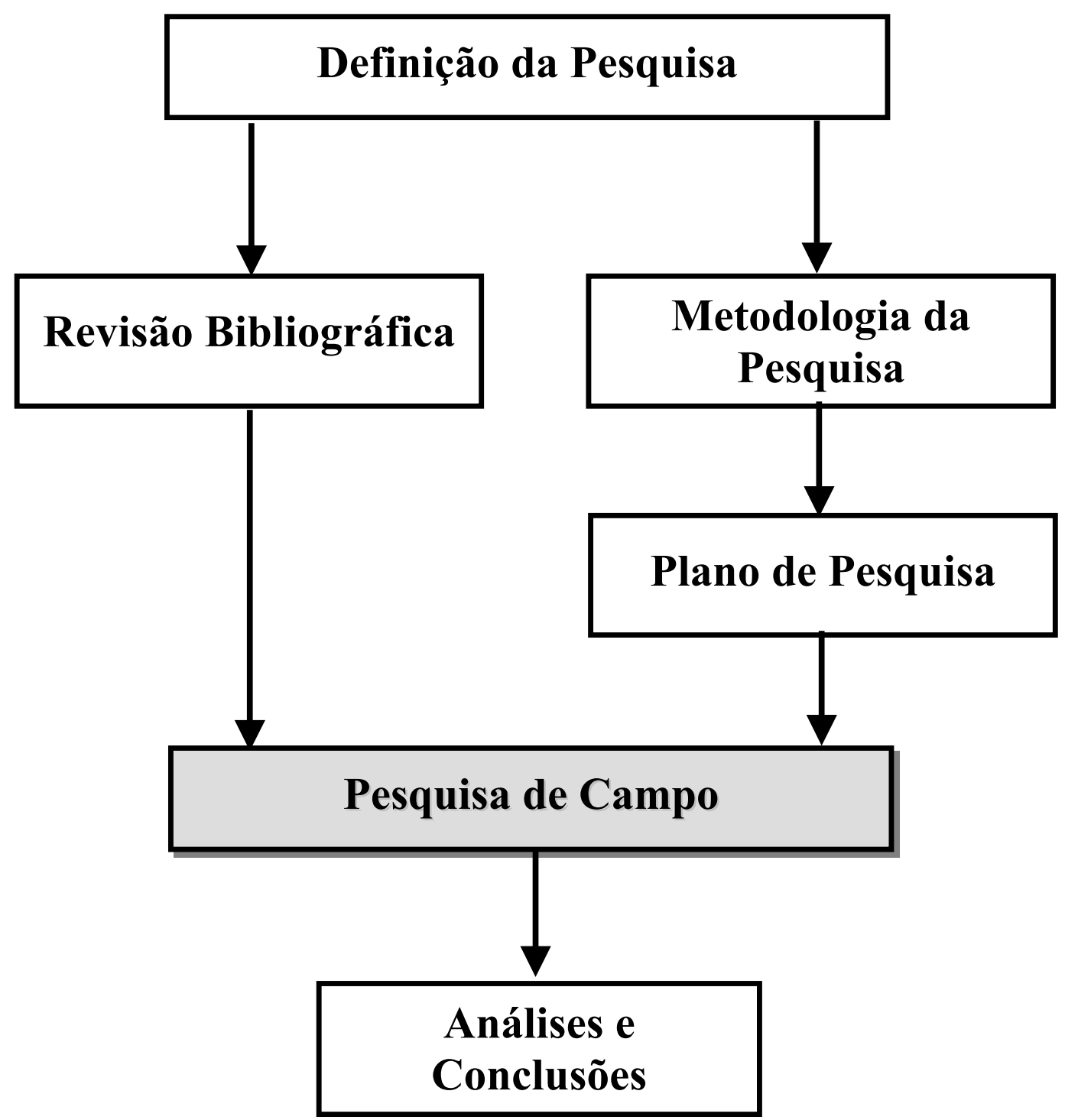




\section{CAPÍTULO 5 - PESQUISA DE CAMPO E ANÁLISE CRÍTICA}

\subsection{Caracterização da Empresa}

A General Motors do Brasil -GMB- é uma das empresas da General Motors Corporation, sediada em Detroit, nos Estados Unidos. A General Motors iniciou suas atividades no setor automotivo no Brasil em 1925, no bairro do Ipiranga, em São Paulo. Suas instalações eram simples, em galpões alugados, e com capacidade de montar 25 veículos por dia, com componentes importados dos Estados Unidos.

Com o sucesso de seus negócios, a General Motors iniciou um ousado plano de expansão de suas atividades e, atualmente, possui quatro complexos industriais, sendo que um dos quais situa-se em São Caetano do Sul (SP), onde também se encontra a matriz da empresa no Brasil. Além destes, a fábrica de Rosário, na Argentina, também é de responsabilidade da GMB.

A General Motors tem investido muito no Brasil para melhorar cada vez mais sua participação no mercado nacional e internacional. Alguns fatos marcantes dos últimos anos são a comercialização de veículos via Internet, o aumento das exportações de veículos CKD para mercados promissores como a Ásia, e o aumento de credibilidade dentro da corporação no desenvolvimento de novos produtos. Este processo se iniciou com a criação de modelos derivados de veículos europeus, posteriormente passou a desenvolver veículos totalmente nacionais, como é o caso do Celta, e mais recentemente, num projeto global, um veículo totalmente novo foi desenhado e projetado no Brasil, que inicia sua produção primeiro no Brasil e depois de seis meses, na Europa.

\subsection{A unidade de análise: Engenharia de Processos de Montagem de Veículos}

A Engenharia de Processos de Montagem de Veículos é responsável pelo planejamento dos processos para a implantação de novos produtos ou novos 
processos produtivos nas plantas de montagem. Em termos de desenvolvimento de novos produtos, que é o foco dessa pesquisa, estão inclusos neste planejamento a análise do projeto do produto e dos equipamentos, ferramentas e dispositivos necessários para a montagem do mesmo, a descrição detalhada da operação de montagem e determinação do conteúdo de trabalho das operações. Também é de responsabilidade da engenharia de processos o acompanhamento da fabricação dos protótipos físicos durante validação do produto na Engenharia Experimental e da fabricação dos veículos de validação dos processos de manufatura, na linha de montagem.

A simulação virtual dos processos de montagem a que nos referimos nesta pesquisa também é de responsabilidade da Engenharia de Processos, cujos engenheiros estão sendo treinados para a realização dessas simulações como complementação do trabalho que anteriormente era feito apenas fisicamente, e agora devem ser analisados primeiramente no computador.

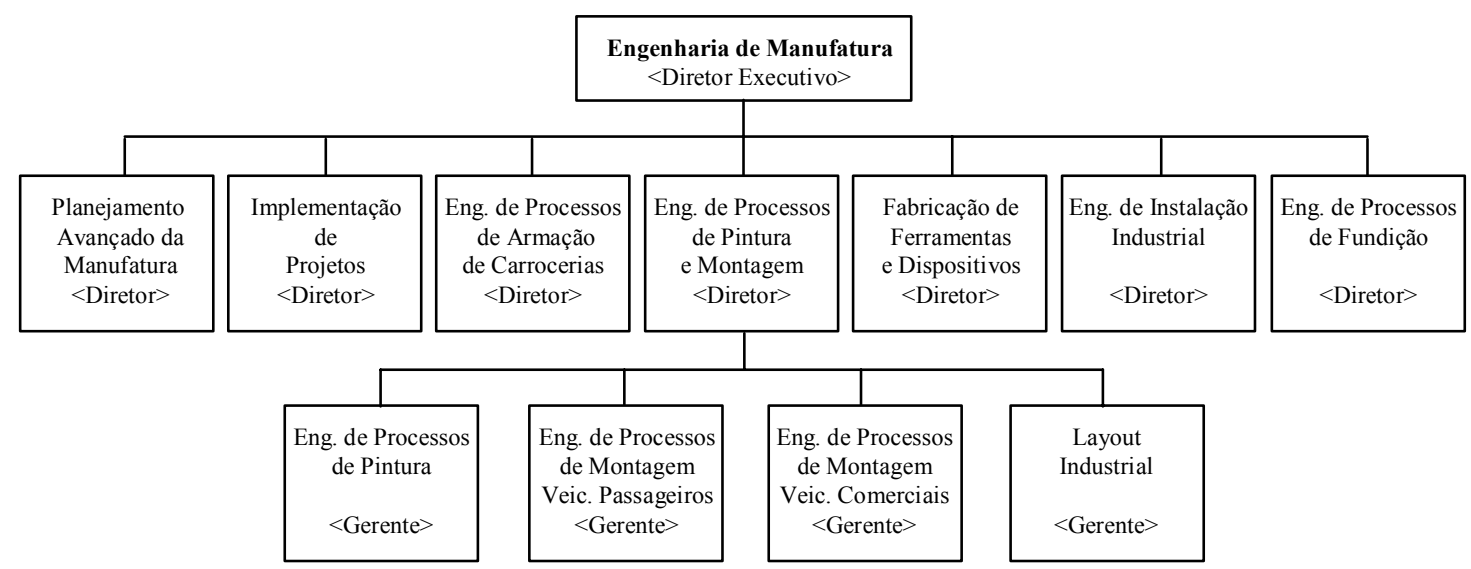

Figura 5.1 Organograma da Eng ${ }^{\mathrm{a}}$ de Manufatura

\subsection{GVDP: O Processo de Desenvolvimento de Produtos da GM}

Buscando comunizar o processo de desenvolvimento de seus veículos, a GM desenvolveu um padrão de planejamento que seja único, porém com pequenas adaptações, em todas as regiões a qual ela conduz atividades de desenvolvimento de novos produtos. Esse padrão global, chamado internamente de GVDP (Global Vehicle Development Process), propõe processos globais competitivos que integram 
as melhores práticas adotadas pelas diversas regiões e permite desenvolver estratégias de divisão do trabalho dentro da corporação e facilitar a implementação dos melhores processos experienciados por qualquer unidade da corporação.

O GVDP é um processo totalmente reformulado tendo em vista as novas e modernas técnicas disponíveis às diversas áreas envolvidas no processo de desenvolvimento e fabricação de veículos. Entre os principais fatores a serem focados por este novo processo, destacam-se:

- Simulações virtuais analíticas do produto e do processo devem preceder qualquer avaliação física propriamente dita.

- Uso de modelos matemáticos verificados e correlacionados como base do programa.

- Minimizar ou, quando possível, eliminar o uso de propriedades físicas como método primário de validação do produto.

- Em caso de modelos derivados da mesma plataforma (mesmo assoalho), deixar de fabricar os primeiros protótipos físicos.

No GVDP todos os eventos são posicionados no tempo a partir da data de lançamento do veículo, ou seja, o início de produção, que determina o marco zero. A partir deste ponto, voltando 48 meses no tempo tem-se o início das atividades de estudo do projeto e a 22 meses do início de produção as informações matemáticas do projetos são "congeladas" e liberadas para a construção dos primeiros protótipos físicos.

As atividades do projeto se iniciam com o planejamento do conceito do veículo, onde são estabelecidas as metas e objetivos a serem atingidos, os requisitos das diversas áreas são alocados e é gerado um cronograma de desenvolvimento detalhado e específico para o projeto.

Numa próxima etapa a arquitetura do veículo é aprovada e inicia-se o desenvolvimento do veículo conceitual. Este veículo conceitual-virtual visa as primeiras identificações da funcionalidade do conceito com a estrutura do assoalho, gerando dados que serão liberados para posterior desenvolvimento dos veículos 
estruturais. O veículo estrutural-virtual é usado para reavaliação da funcionalidade do veículo com a inclusão dos itens superiores da estrutura do veículo (motor, transmissão, suspensões etc). Nesta etapa todas as áreas de manufatura aprofundam no desenvolvimento dos processos de fabricação e iniciam a construção de ferramentas e dispositivos e a aquisição de novos equipamentos.

A seguir, temos um ponto de checagem do processo onde as características do exterior e do interior do veículo são aprovadas, e as características de estilo são “congeladas" para o desenvolvimento dos veículos de integração. No veículo de integração-virtual é feita a avaliação final da funcionalidade do veículo, com o mesmo já completamente modelado. As informações são consistentes e serão progressivamente liberadas para a fabricação dos primeiros protótipos físicos. Neste período tem-se o início da preparação da planta para receber novo veículo e um grupo de pessoas são treinadas e têm os primeiros contatos com o veículo.

Na etapa seguinte, todas as informações matemáticas são liberadas para a construção dos primeiros protótipos físicos, o veículo de integração-físico. O veículo de integração-físico é destinado à validação e correlação com o que foi simulado virtualmente, tanto na Engenharia de Produtos como na Engenharia de Manufatura. Representa a integração de todos os componentes e subsistemas e valida a seqüência de montagem. Após a construção dos primeiros protótipos físicos, são validadas as folhas de instruções de montagem e liberadas para a planta para a construção dos primeiros veículos a serem fabricados na linha de montagem. Também são instalados todos os equipamentos, ferramentas e dispositivos de montagem. O veículo de validação da manufatura (não-vendáveis) é destinado à identificação e resolução dos problemas de processo e ao aprendizado dos operadores. Estes veículos também são utilizados para a análise e correlação dos resultados de simulação.

Existe ainda uma etapa que precede o início de produção, que consiste na continuação da validação anteriormente descrita, através da montagem de veículos vendáveis, que dispõe de $100 \%$ das peças aprovadas pela Engenharia da Qualidade.

Como se pode notar, o momento mais apropriado para a análise dos processos de montagem do produto em desenvolvimento através das simulações 
virtuais se dá durante o desenvolvimento do veículo estrutural e de integração, por se tratarem de protótipos virtuais, conforme representado na figura 5.2.

Estes protótipos são constituídos de componentes ou conjuntos que possuem o mesmo nível de liberação e permitem simular virtualmente a integração dos equipamentos de montagem com o produto e garantir que este atenda às necessidades de manufatura. Após este período, os desenhos são liberados para construção do ferramental de produção e portanto, ainda que possam ser executadas, as alterações no produto podem causar forte impacto em custos e prazos. 


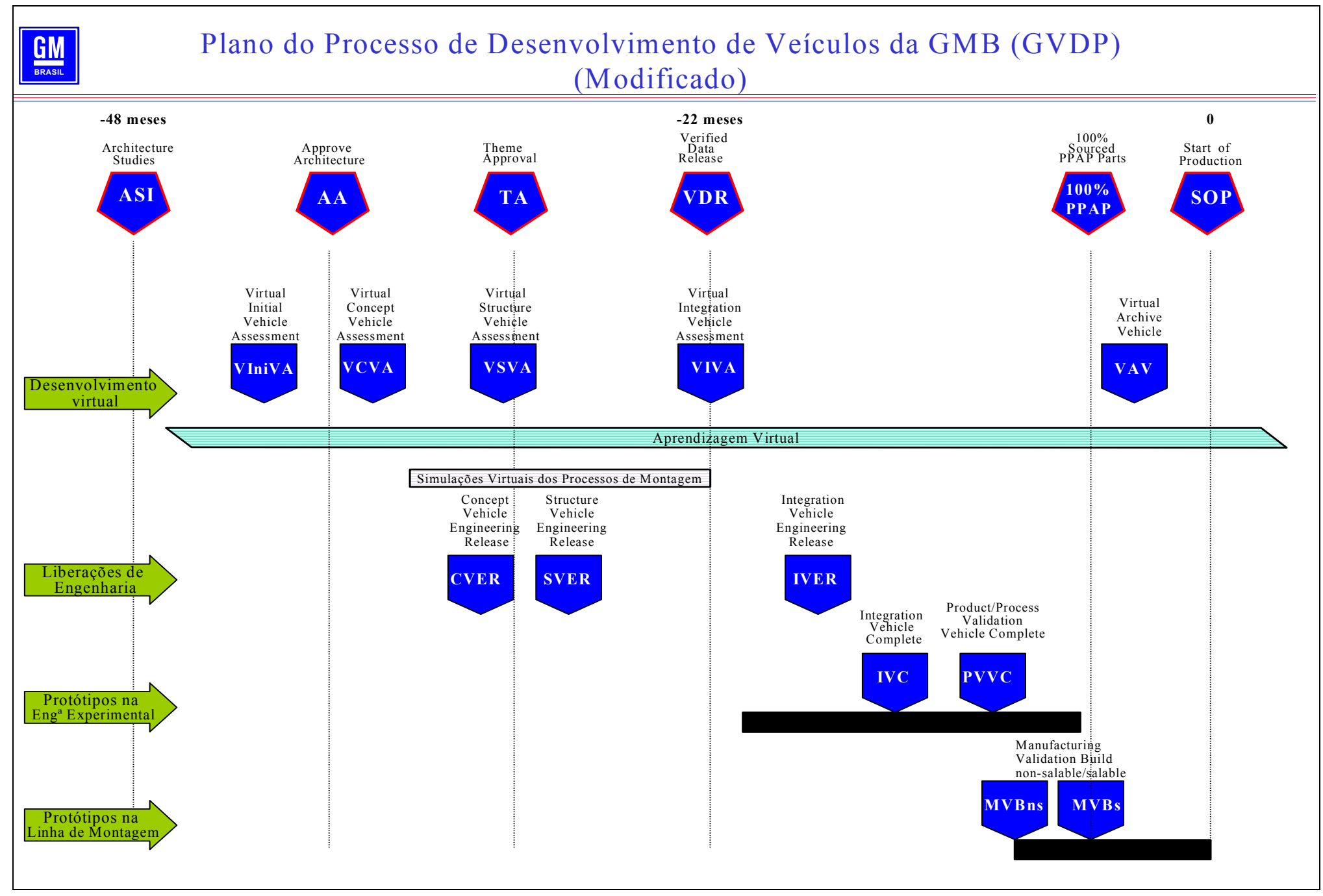

Figura 5.2 O plano do processo de desenvolvimento de veículos da GMB (modificado) 


\subsection{Os meios de troca de Informações e Gerenciamento de Dados}

Como vimos anteriormente, o processo de desenvolvimento de produtos requer uma combinação eficaz entre uma imensa quantidade de informações sobre o produto, design e a manufatura do mesmo. Atualmente, a competitividade da indústria automobilística está fortemente relacionada ao uso de tecnologias de informação e comunicação, que são o suporte necessário e fundamental para a integração entre os diversos departamentos da empresa e também dos fornecedores externos e de seus sub-fornecedores. Além disso, facilita a coordenação e a colaboração das pessoas envolvidas no projeto, no desenvolvimento e na manufatura, integrando essas áreas com um conjunto de ferramentas computacionais que permitem a aplicação da Engenharia Simultânea.

Para atingir os objetivos propostos pelo GVDP, descritos na seção anterior, e reduzir os investimentos necessários para o desenvolvimento de novos produtos, tornou-se necessário construir um ambiente de trabalho integrado para as Engenharias, cujo acesso aos dados do produto seja feito de forma única e consistente. Assim, a GM com suas unidades elegeram alguns parceiros da tecnologia da informação para implementação da estratégia imaginada. O fluxo de dados, ilustrado na figura 5.3, se baseia na utilização do UG (Unigraphics) e do GM iMAN (General Motors information MANager), produtos da Unigraphics Solutions, adaptados ao uso da GM, circulando numa infra-estrutura de abrangência mundial, armazenados de forma única, consistente e robusta.

Neste ambiente, o UG gera o modelo matemático, tanto para a Engenharia de Produtos como para a Engenharia de Manufatura. Essas informações são gerenciadas pelo GMiMAN, que as organiza de forma conveniente para o usuário e possibilita ao projetista controlar a versão do trabalho em execução e liberá-la para utilização. O workflow também é gerenciado, permitindo aos usuários dos sistema disparar e acompanhar o status dos diversos serviços em andamento.

Para as simulações de manufatura, o tema central deste trabalho, foi escolhido um software de visualização chamado Product Vision, o PV, também de 
propriedade da Unigraphics Solutions. Essa ferramenta de Visualização foi considerada a mais adequada por gerar um ambiente tridimensional real que permite estabelecer comunicação e visualização das soluções de fabricação do veículo em múltiplas perspectivas.

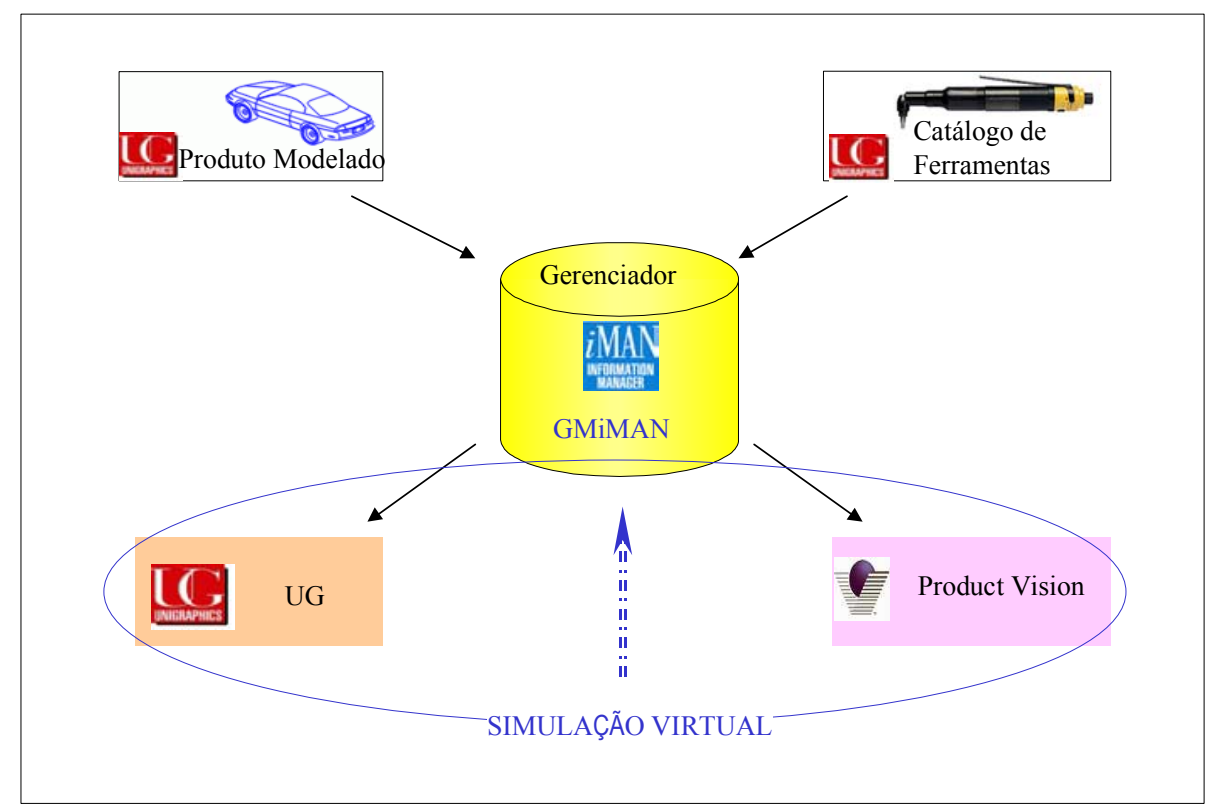

Figura 5.3 Fluxo de dados da simulação virtual

Para cada arquivo UG, que contém os dados matemáticos do modelo, é gerado um arquivo correspondente PV, que não contém as informações matemáticas mas apenas a superfície externa do modelo. Este arquivo PV é bem menor que o arquivo UG e por isso sua manipulação é mais simples e mais barata, por não requerer equipamentos tão potentes como o UG. Ambos os arquivos são gerenciados pelo GMiMAN, de forma semelhante ao Gerenciador de Arquivos do Windows, pelo sistema de pastas.

Para a simulação, cabe ao usuário, no caso o Engenheiro de Manufatura, escolher as ferramentas de montagem existentes na fábrica e digitalizadas dentro do Catálogo de Ferramentas e a melhor forma de visualização dos dados do projeto, em função de suas necessidades e do software disponível em sua máquina. 


\subsection{Procedimentos para a Simulação Virtual}

Para se obter resultados de qualidade e que sejam confiáveis, o processo de simulação virtual de um sistema para detecção de interferências entre os equipamentos de montagem e o produto deve envolver uma preparação inicial. Assim, cabe ao Engenheiro de Processos responsável a certificação de que todos os elementos essenciais ao processo de simulação estejam sob controle. Lista-se a seguir alguns elementos essenciais que devem preceder a simulação:

- Desenvolver estratégias e requisitos.

- Estabelecer os parâmetros de simulação.

- Solicitar e correlacionar inputs da Planta.

- Estabelecer contato com o Engenheiro de Produto.

- Obter informações matemáticas das ferramentas necessárias.

- Confirmar acesso aos dados da Engenharia de Produtos.

- Confirmar uso da versão correta.

A simulação deve ser realizada a partir das últimas informações liberadas pela Engenharia de Produto e disponíveis no gerenciador GMiMAN, as quais são identificadas por versões de liberação e que possuem regras estabelecidas. Caso haja alteração no desenho do produto no decorrer ou após a execução da simulação, o engenheiro de manufatura é notificado e a nova situação deve ser reavaliada para, se for o caso, refazer os estudos.

Os resultados obtidos através da realização de cada simulação devem ser divulgados às diversas áreas envolvidas, da Manufatura e da Engenharia de Produto. Para uma melhor organização e apresentação dos resultados, foi desenvolvido uma máscara para a emissão dos relatórios, ilustrada na figura 5.4, com campos específicos para a descrição dos acontecimentos do estudo:

- Identificação do estudo: breve descrição do tipo de simulação e área analisada.

- Identificação do grupo de trabalho: engenheiros responsáveis pela simulação, pelos componentes, projetistas e outras pessoas envolvidas. 
- Dados do projeto: identificação do projeto, data da simulação.

- Objetivos da simulação: deve conter informações básicas que justifiquem a análise virtual dos processos de montagem de tais componentes.

- Especificações do projeto: estabelecimento dos requisitos do produto e sua integração com processos de montagem a serem utilizados na planta de montagem.

- Equipamentos: determinação dos equipamentos de montagem a serem utilizados na planta.

- Resultados: após realização da simulação, descreve-se neste campo os resultados obtidos com a mesma.

- Ilustração da simulação: campo destinado à apresentação ilustrativa dos resultados da simulação, contendo imagens com vistas, cortes, seções ou arquivos com a animação da simulação (filme).

- Conclusões: após uma análise crítica dos resultados obtidos, descrevese neste campo a existência ou não de interferências entre equipamentos de montagem e o produto, suas implicações e possíveis soluções. Caso ocorram tais interferências, o preenchimento do relatório deve ser continuado, apresentando as soluções encontradas no reprojeto. Os três últimos campos foram designados para este fim.

- Solução adotada: descreve a solução encontrada após reavaliação do projeto, feita em conjunto pelos engenheiros de produto e de manufatura.

- Ilustração da solução: apresentação ilustrativa da condição final obtida.

- Benefícios: descrever os benefícios técnicos e econômicos obtidos pela adoção de simulações virtuais dos processos de montagem do sistema analisado.

Após a realização da simulação, divulgação dos relatórios às áreas afetadas 
e a documentação dos resultados obtidos, o Engenheiro de Processos deve aguardar a fabricação dos protótipos físicos para validar a solução encontrada através da simulação virtual.

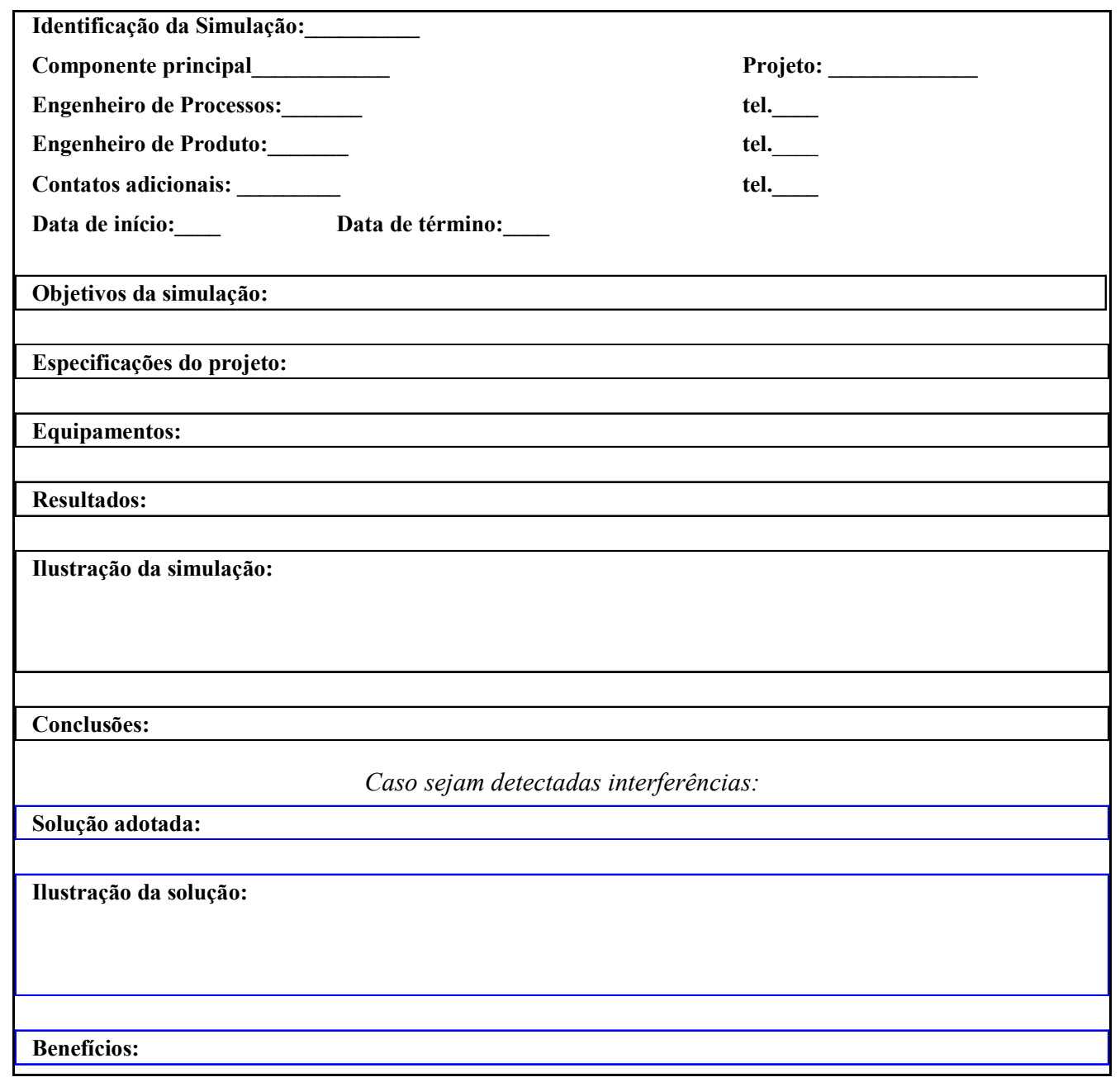

Figura 5.4 Máscara para relatório da simulação virtual

\subsection{Os estudos de caso}

Para a realização dos estudos de caso, foi definida a utilização dos dados obtidos de dois projetos denominados A16 (um veículo de passeio) e A03 (uma pickup pequena). No primeiro foram escolhidas algumas interferências dimensionais entre equipamentos de montagem e o produto e que foram detectadas apenas após a produção de protótipos, quando o produto já estava definido ou até mesmo, prestes a entrar em produção. No segundo, analisamos algumas operações para verificar a 
existência de interferências de montagem durante o desenvolvimento do produto, bem antes da construção dos protótipos físicos. Trata-se da utilização da tecnologia de simulação virtual dos processos de montagem.

Para podermos estudar e comparar estes casos ocorridos em dois diferentes projetos e durante períodos de tempo também distintos, precisamos analisar as condições e os recursos utilizados no desenvolvimento dos mesmos.

A partir de um pesquisa interna na GMB, gerou-se um comparativo da tecnologia empregada em ambos os projetos, identificados na tabela 5.1. A pesquisa nos revela a continuidade na adoção de alguns recursos de projeto relativamente novos e de outros já consagrados no ramo de desenvolvimento de novos produtos e também, o que é mais importante, a busca da empresa por novas ferramentas que lhe auxilie reduzir os custos e prazos de desenvolvimento e reagir de forma mais ágil às mudanças exigidas pelo mercado.

\begin{tabular}{|c|c|c|c|}
\hline Área & Tecnologia empregada & Proj A16 & Proj A03 \\
\hline \multirow{6}{*}{$\begin{array}{l}0 \\
\underline{1} \\
\overline{0} \\
\frac{\pi}{2}\end{array}$} & Mock-up digital (DMU) & Sim & Sim \\
\hline & Simulação de Crash Test & $\operatorname{Sim}$ & $\operatorname{Sim}$ \\
\hline & Análise Estrutural por Elementos Finitos & Sim & Sim \\
\hline & Modelamento matemático em UG & Sim & Sim \\
\hline & Ambiente integrado de armazenamento de informações (GMiMAN) & Sim & Sim \\
\hline & $\begin{array}{l}\text { Especificações técnicas estabelecidas no plano de desenvolvimento } \\
\text { de produtos (4Phase ou GVDP) }\end{array}$ & Sim & Sim \\
\hline \multirow{4}{*}{ 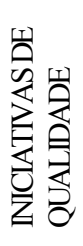 } & Aplicação de DFM/A & Sim & Sim \\
\hline & Aplicação de FMEA & Sim & Sim \\
\hline & Uso de Engenharia Robusta & $\operatorname{Sim}$ & Sim \\
\hline & Engenharia Simultânea & Sim & Sim \\
\hline \multirow{3}{*}{ 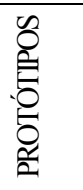 } & Prototipagem rápida & $\operatorname{Sim}$ & Sim \\
\hline & Substituição de protótipos físicos por protótipos virtuais & Não & $\operatorname{Sim}$ \\
\hline & Workshops para análise de protótipos físicos/virtuais & $\operatorname{Sim}$ & $\operatorname{Sim}$ \\
\hline \multirow{5}{*}{ 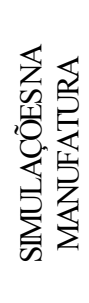 } & Formação de um time de VAS (Virtual Analysis and Simulation) & Não & Sim \\
\hline & Simulações Virtuais dos Processos de Montagem & Não & Parcial \\
\hline & Treinamento do grupo de trabalho em VAS & Não & Parcial \\
\hline & Layout virtual de Fábrica & Não & Parcial \\
\hline & Análise Virtual de Estampagem & Sim & Sim \\
\hline
\end{tabular}

Tabela 5.1 Análise comparativa dos recursos utilizados nos projetos A16 e A03 
Algumas das principais mudanças que vem sendo adotadas é a redução do número de protótipos físicos nas primeiras etapas do projeto, os quais são substituídos por protótipos virtuais. Este novo conceito de validação do produto é inclusive um dos pontos-chave do novo plano de desenvolvimento de produtos da GM, o GVDP.

Como parte dessa evolução no processo de desenvolvimento de produtos, a Manufatura também vem se preparando para se utilizar desses mesmos protótipos virtuais no desenvolvimento de seus processos produtivos. Para isso, foi criado um grupo de trabalho para desenvolver o uso de Análises e Simulações Virtuais (VAS). Com base no que se está fazendo atualmente nos EUA, onde esta tecnologia vem sendo empregada há pelo menos dois anos, este grupo está sendo treinado para a utilização de diferentes softwares de modelagem e visualização $3 \mathrm{D}$, manipulação de arquivos e outros necessários à realização das simulações virtuais. O grupo de VAS é formado por representantes das Engenharias de Processos de Montagem, Pintura, Estruturação de Carrocerias e Layout Industrial, além da integração com a Engenharia de Produtos, e que são responsáveis pela realização das simulações em suas respectivas áreas.

No entanto, as especificações técnicas do veículo também são cada vez mais exigentes, onde busca-se melhorar a performance do produto e atender a novos requisitos e normas. Muitas vezes essas exigências são atendidas através da redução de folgas e tolerâncias de montagem, desenvolvimento de novos materiais, novos métodos produtivos etc., ocasionando a geração natural de problemas de montagem durante a criação do novo produto.

Isso nos permite analisar no estudo de caso dois projetos distintos e que ocorreram em épocas diferentes, onde os problemas que ainda nos deparamos no Projeto A03, apesar do emprego de uma tecnologia de projeto mais avançada, que conta inclusive com a aplicação de simulações virtuais de montagem, também teriam ocorridos durante o desenvolvimento do projeto anterior, com a diferença de que neste caso esses problemas só puderam ser identificados após a montagem dos protótipos físicos. 


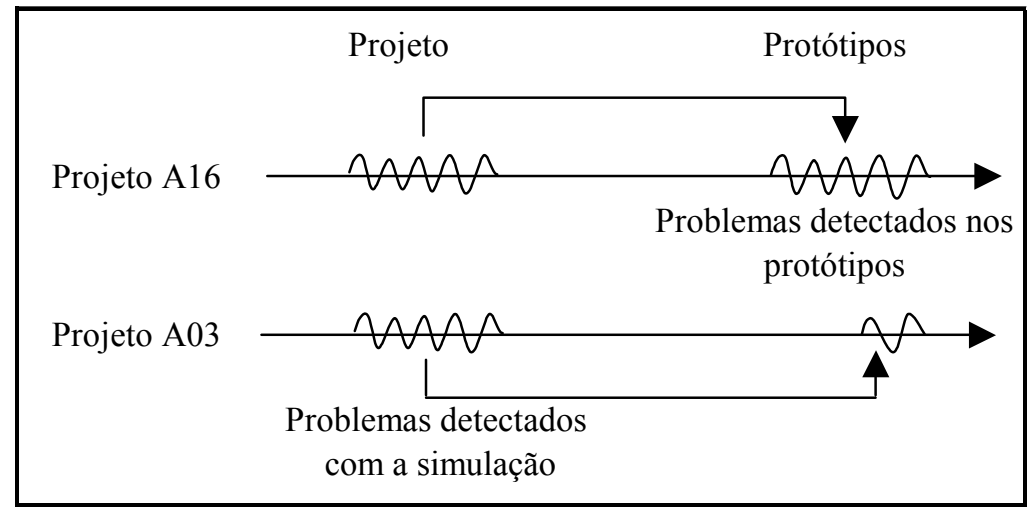

Figura 5.5 A detecção de interferências em dois projetos, antes e após as simulações virtuais

Tal fato reforça a importância da detecção de interferências dimensionais entre partes e equipamentos de montagem o quanto antes possível, ainda na fase de concepção do produto, para que as melhores soluções sejam implementadas com menores custos e sem impactar os prazos do programa.

\subsection{Os dados levantados}

Conforme mencionado anteriormente, neste trabalho iremos analisar os dados de dois projetos distintos, denominados A16 e A03. No Estudo de Caso A, avaliamos as conseqüências causadas por algumas interferências de montagem que foram detectadas tardiamente durante o desenvolvimento do projeto A16.

No Estudo de Caso B, discutimos o uso das simulações virtuais durante o desenvolvimento do projeto A03, voltado principalmente à detecção de possíveis interferências entre os equipamentos de montagem e o produto, permitindo alterações no produto para garantir que os processos e equipamentos previamente estabelecidos sejam capazes.

\subsubsection{Estudo de Caso A: Projeto A16}

\subsubsection{A detecção de interferências sem o uso de simulações}

A análise dos dados revela que no Projeto A16, quando os processos de montagem não foram avaliados virtualmente na manufatura, aproximadamente a metade das interferências entre os equipamentos de montagem e o produto foram 
identificadas somente durante a montagem e avaliação dos protótipos físicos na Engenharia Experimental. Neste caso, os desenhos das peças já estavam liberados e a fabricação do ferramental de produção já havia sido iniciada, sendo que algumas já estavam prontas.

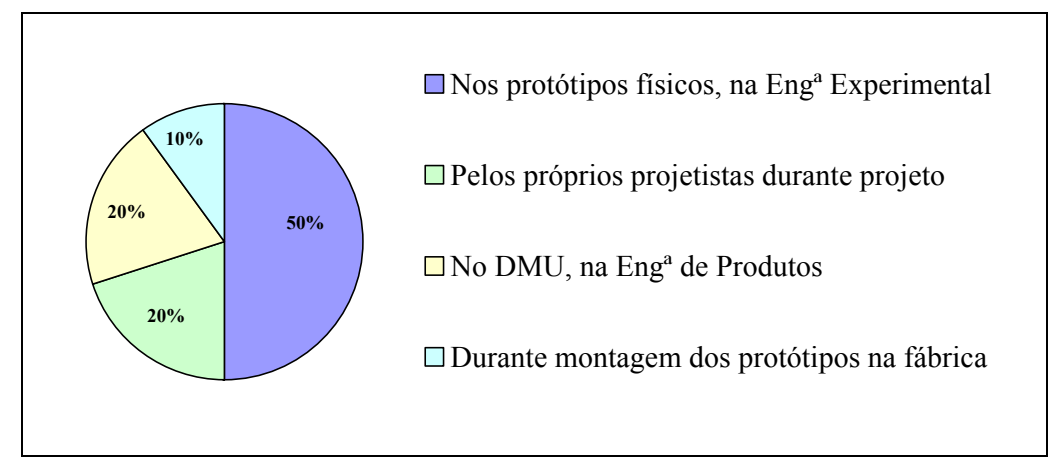

Figura 5.6 Local da detecção de interferências no Projeto A16

Ainda mais grave, uma parcela de interferências só pôde ser detectada durante a montagem dos protótipos na fábrica, quando o produto já estava todo definido, gerando necessidade de alterações no projeto e no processo produtivo.

Com relação a essas interferências detectadas somente após a liberação dos desenhos, os entrevistados apontaram como fatores determinantes na escolha da solução final o levantamento dos custos de modificação do produto e do equipamento de montagem e do tempo necessário à realização dessas modificações do produto e do equipamento, ilustrado na figura 5.7. Os custos para a modificação do produto geralmente estão relacionados às horas de retrabalho do projeto, ao material e horas gastas para o retrabalho das ferramentas de estampagem e dos dispositivos de inspeção e às alterações dos custos das peças compradas. Os custos para a modificação dos equipamentos são normalmente relacionados à adequação dos equipamentos existentes ao novo produto ou da aquisição de novos equipamentos, considerando inclusive as horas de engenharia para o acompanhamento das modificações.

A determinação da solução final a ser adotada também deve levar em consideração a análise do impacto na linha de montagem, que dependendo da solução, pode ocasionar um acréscimo no tempo de operação, prejudicar a 
ergonomia para o operador, exigir alterações na seqüência de montagem e no layout da fábrica, entre outros.

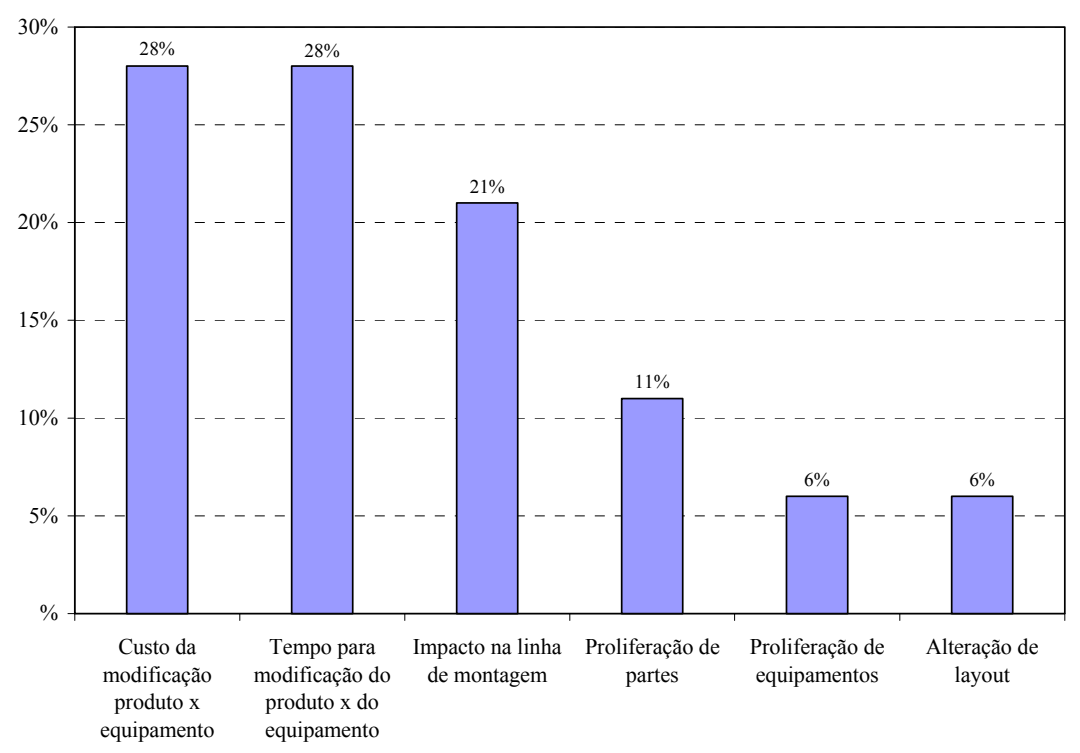

Figura 5.7 Fatores considerados na resolução de interferências no Projeto A16

\subsubsection{Interferências avaliadas no Projeto A16}

A análise de três interferências ocorridas no Projeto A16 nos mostra quais os fatores que foram considerados na resolução dos problemas de interferências de montagem encontrados durante fabricação dos protótipos físicos. No primeiro caso, houve uma interferência do gancho transportador de veículos na linha aérea e o painel inferior do veículo. Essa interferência só foi detectada durante montagem dos protótipos na linha de montagem e por isso a proposta de modificação da região inferior do painel lateral do veículo apresentou custos elevados com grande consumo de horas de gerenciamento para não comprometer os prazos do programa. A solução adotada foi o retrabalho do equipamento para permitir acoplamento do mesmo ao novo veículo.

O segundo item analisado é a fixação do mecanismo limpador do parabrisa, onde foi detectada uma interferência entre a apertadeira existente para esta operação e o capô do veículo. Também neste caso a solução de alteração do produto é inviabilizada por apresentar custos e prazos muito elevados. A solução adotada é o uso de um novo modelo de apertadeira específica para esta operação. 
Por último, analisamos a fixação da tampa da caixa de relês, que normalmente deveria ser fixada com uma apertadeira tipo pistola, e que devido a posição de um dos parafusos, a mesma interfere com a carroceria. A solução seria alterar a posição do parafuso ou o ângulo de fixação do mesmo, porém os altos custos envolvidos e o prazo para modificar as ferramentas de injeção da tampa e da caixa impossibilitaram a adoção dessa solução. Também neste caso foi necessário uma nova ferramenta para esta operação.

O estudo completo de cada interferência analisada no Projeto A16 encontrase no Anexo B. A tabela abaixo apresenta a compilação dos dados obtidos:

\begin{tabular}{|c|c|c|c|c|c|}
\hline INTERFERÊNCIA & ALTERAÇÃO & $\begin{array}{c}\text { CUSTO } \\
{[\$]}\end{array}$ & $\begin{array}{c}\text { PRAZO } \\
\text { [SEM.] }\end{array}$ & $\begin{array}{l}\text { IMPACTO } \\
\text { L. MONT. }\end{array}$ & FATORES CONSIDERADOS \\
\hline \multirow{2}{*}{$\begin{array}{l}\text { A1: Instalação } \\
\text { do eixo traseiro }\end{array}$} & Produto & 200.000 & 14 & - & $\begin{array}{l}\text {-Horas de retrabalho do projeto } \\
\text {-Horas de retrabalho das ferramentas } \\
\text { de estampagem } \\
\text {-Horas de retrabalho dos dispositivos } \\
\text { de inspeção }\end{array}$ \\
\hline & Equipamento & 120.000 & 4 & Alto & $\begin{array}{l}\text {-Custos de adequação do equipamento } \\
\text { existente ao produto } \\
\text {-Horas de engenharia para } \\
\text { acompanhamento das modificações } \\
\text {-Paradas de linha } \\
\text { - Acréscimo no tempo de montagem }\end{array}$ \\
\hline \multicolumn{2}{|c|}{ Solução adotada: } & \multicolumn{4}{|c|}{ Retrabalho do equipamento de montagem } \\
\hline \multirow{2}{*}{$\begin{array}{l}\text { A2: Fixação do } \\
\text { mecanismo } \\
\text { limpador do } \\
\text { parabrisa }\end{array}$} & Produto & 50.000 & 7 & - & $\begin{array}{l}\text {-Horas de retrabalho do projeto } \\
\text {-Horas de retrabalho das ferramentas } \\
\text { de injeção das bases do mecanismo }\end{array}$ \\
\hline & Equipamento & 10.000 & 8 & Baixo & $\begin{array}{l}\text { - Custo das novas apertadeiras } \\
\text {-Horas de engenharia para o processo } \\
\text { de compra e instalação } \\
\text { - Acréscimo no tempo de montagem } \\
\text {-Proliferação de equipamentos }\end{array}$ \\
\hline \multicolumn{2}{|c|}{ Solução adotada: } & \multicolumn{4}{|c|}{ Nova ferramenta de montagem } \\
\hline \multirow{2}{*}{$\begin{array}{l}\text { A3: Fixação da } \\
\text { tampa da caixa } \\
\text { de relês }\end{array}$} & Produto & 65.000 & 10 & - & $\begin{array}{l}\text { - Horas de retrabalho do projeto } \\
\text {-Horas de retrabalho das ferramentas } \\
\text { de injeção da tampa e da caixa }\end{array}$ \\
\hline & Equipamento & 5.000 & 8 & Baixo & $\begin{array}{l}\text { - Custo da nova apertadeira } \\
\text {-Horas de eng. para acompanhamento } \\
\text { do processo de compra e instalação } \\
\text { - Proliferação de equipamentos }\end{array}$ \\
\hline
\end{tabular}

Tabela 5.2 Quadro resumo do Estudo de Caso A - Projeto A16. 


\subsubsection{Conclusões sobre as proposições}

\section{- Proposição H1}

As modificações no projeto para eliminar as interferências que foram detectadas nos protótipos físicos apresentaram custos elevados devido, principalmente, à necessidade de retrabalho do ferramental de produção dos componentes. Dessa forma, os equipamentos de montagem tiveram que ser retrabalhados ou novos equipamentos foram adquiridos para atender o produto, acarretando custos também altos porém menores. Tal fato revela a importância da aplicação das simulações virtuais durante o desenvolvimento do veículo, quando os desenhos ainda não foram liberados para construção das ferramentas. Assim, as modificações exigidas caso interferências sejam detectadas são menos penosas ao programa.

Pelo exposto, confirmamos a validade da proposição H1: "O crescimento da aplicação de simulações virtuais em projetos de veículos contribui para a redução de custos adicionais em equipamentos de montagem, novos ou retrabalhos de existentes".

\section{- Proposição H2}

Como se pôde verificar na figura 5.6, apenas $40 \%$ dos problemas de interferências entre o produto e os equipamentos estabelecidos para a montagem do mesmo foram detectados durante o desenho do produto. Os outros $60 \%$ foram detectados somente com a construção de protótipos físicos, sendo portanto confirmada a proposição $\mathbf{H 2}$ : “O crescimento da aplicação de simulações virtuais em projetos de veículos aumenta a deteç̧ão de interferências dimensionais entre partes e equipamentos numa montagem, durante a fase de projeto". 


\subsubsection{Estudo de Caso B: Projeto A03}

\subsubsection{O uso de simulações virtuais}

A relevância do objeto de estudo dessa pesquisa pode ser observada na figura 5.8, onde são apresentados os dados coletados junto às pessoas entrevistadas e que revelam a importância da aplicação das simulações virtuais dos processos de montagem para a identificação de interferências entre os equipamentos de montagem e o produto.

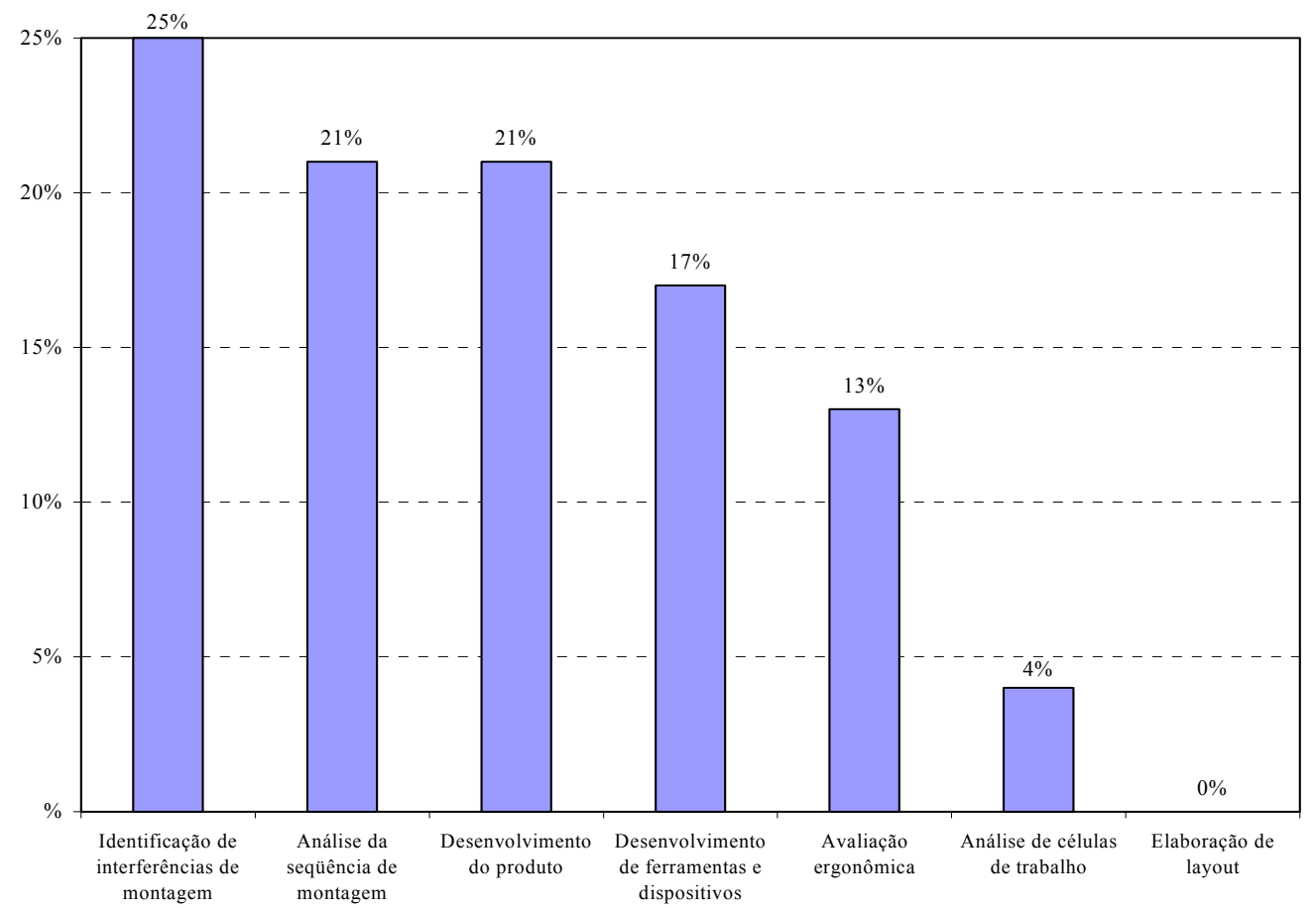

Figura 5.8 A aplicação de simulações virtuais na Eng ${ }^{\mathrm{a}}$ Processos de Montagem

Também foi levantada a possibilidade de se analisar virtualmente a seqüência de montagem do produto, permitindo validar antecipadamente a introdução do novo produto de acordo com as características específicas da planta de montagem.

A questão também destaca que o uso das simulações virtuais está bastante relacionado ao desenvolvimento de novos produtos. Tal fato se justifica pela existência de um projeto com recursos devidamente alocados para $o$ desenvolvimento do mesmo e a necessidade de avaliação do produto virtualmente, já 
que o novo plano de desenvolvimento de produtos (GVDP) não prevê a construção de protótipos físicos nas primeiras etapas do projeto, quando o projeto permite alterações do produto com mínimo impacto em custos e prazos de desenvolvimento.

Além desses fatores, a tabela 5.3 mostra outras melhorias que podem ser obtidas com a adoção de simulações virtuais nos projetos de montagem. Dentre essas, as que mereceram maior destaque por parte dos entrevistados são as que obtiveram maior classificação segundo o critério de valores definidos abaixo:

1- Nenhuma importância

2- Pequena contribuição

3- Bastante importante

4- Importância moderada

5- Importância total

\begin{tabular}{|l|c|c|c|c|c|}
\hline \multicolumn{1}{|c|}{ MELHORIA PRETENDIDA } & \multicolumn{5}{c|}{ RESULTADO } \\
\cline { 2 - 6 } & $\mathbf{1}$ & $\mathbf{2}$ & $\mathbf{3}$ & $\mathbf{4}$ & $\mathbf{5}$ \\
\hline Padronização de equipamentos & & & $20 \%$ & $50 \%$ & $30 \%$ \\
\hline Análise de dispositivos de montagem & & & $10 \%$ & $45 \%$ & $45 \%$ \\
\hline Agilização no processo de liberação do trabalho & & & $40 \%$ & $60 \%$ & \\
\hline Autonomia da área para desenvolver trabalho & $10 \%$ & $50 \%$ & $40 \%$ & & \\
\hline Criação de banco de dados de peças & & $60 \%$ & $40 \%$ & & \\
\hline Trabalho simultâneo com demais áreas & & & & $60 \%$ & $40 \%$ \\
\hline Trabalho em avançado permite melhorias do processo & & & & $30 \%$ & $70 \%$ \\
\hline
\end{tabular}

Tabela 5.3 Outras melhorias pretendidas com o uso de simulações virtuais

Analisando-se a tabela acima, verificamos que a maior parte do grupo considerou de extrema importância a possibilidade da Engenharia de Manufatura realizar seu trabalho antecipadamente, desde o início do projeto e de forma simultânea com as demais áreas.

Os entrevistados também destacaram como vantagem do uso de simulações virtuais dos processos de montagem a análise dos equipamentos e dispositivos de montagem, visando que estes sejam padronizados ao máximo e evitando assim a proliferação dos equipamentos para a realização de operações similares em diferentes modelos de veículos. 
Também foi apontado pelo grupo a agilização no processo de liberação do trabalho, quando a definição dos processos de montagem pode ser realizada mais antecipadamente dentro do cronograma do projeto. Os dados gerados pelas simulações virtuais ficam registrados nos relatórios que são emitidos após cada simulação e contém todas as informações necessárias à criação das folhas de instruções de montagem pela Engenharia de Processos.

\subsubsection{As simulações nos cronogramas dos projetos}

A pesquisa nos revela a necessidade de aproveitar o momento adequado no processo de desenvolvimento de um produto novo para se fazer as análises virtuais dos processos de montagem. Conforme já apresentado anteriormente no Plano de Desenvolvimento de Produtos da GM (figura 5.2), ela nos mostra que esse momento se dá durante o desenvolvimento e desenho do produto, quando são desenvolvidos os protótipos virtuais, identificados como veículo estrutural e veículo de integração.

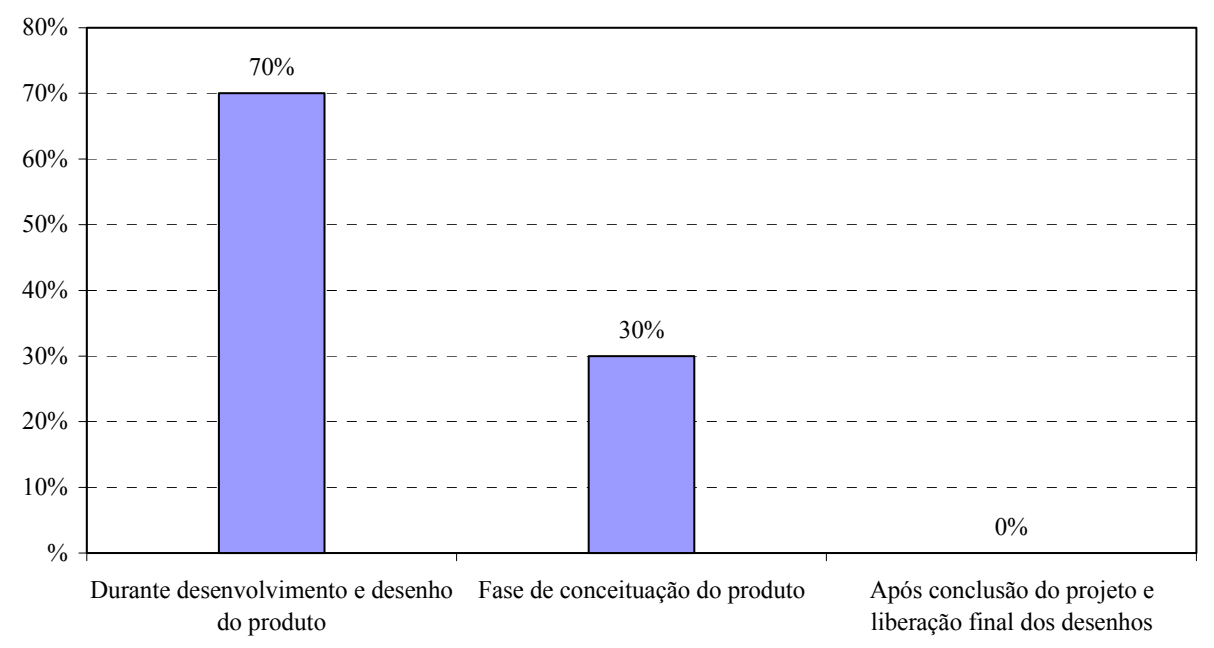

Figura 5.9 Momento mais adequado para uso das simulações

Também nos revela o anseio dos entrevistados no uso das simulações durante a conceituação do produto e desenvolvimento do veículo conceitual. No entanto, nesta fase de definição da arquitetura do veículo, dificilmente todas as informações necessárias às simulações virtuais estarão disponíveis, pois nesta etapa são freqüentes as modificações da superfície de design e, por conseqüência, do desenho do produto. 


\subsubsection{Os requisitos de montagem}

Segundo os dados levantados, os requisitos de manufatura referentes aos equipamentos e processos de montagem que serão utilizados na produção e que portanto serão utilizados durante as simulações, devem ser levados ao conhecimento dos projetistas principalmente através das reuniões de grupo e da realização de workshops para análise dos protótipos virtuais. Reforçando assim a importância da Engenharia Simultânea para o desenvolvimento de produtos e, consequentemente, na aplicação das simulações virtuais dos processos de montagem.

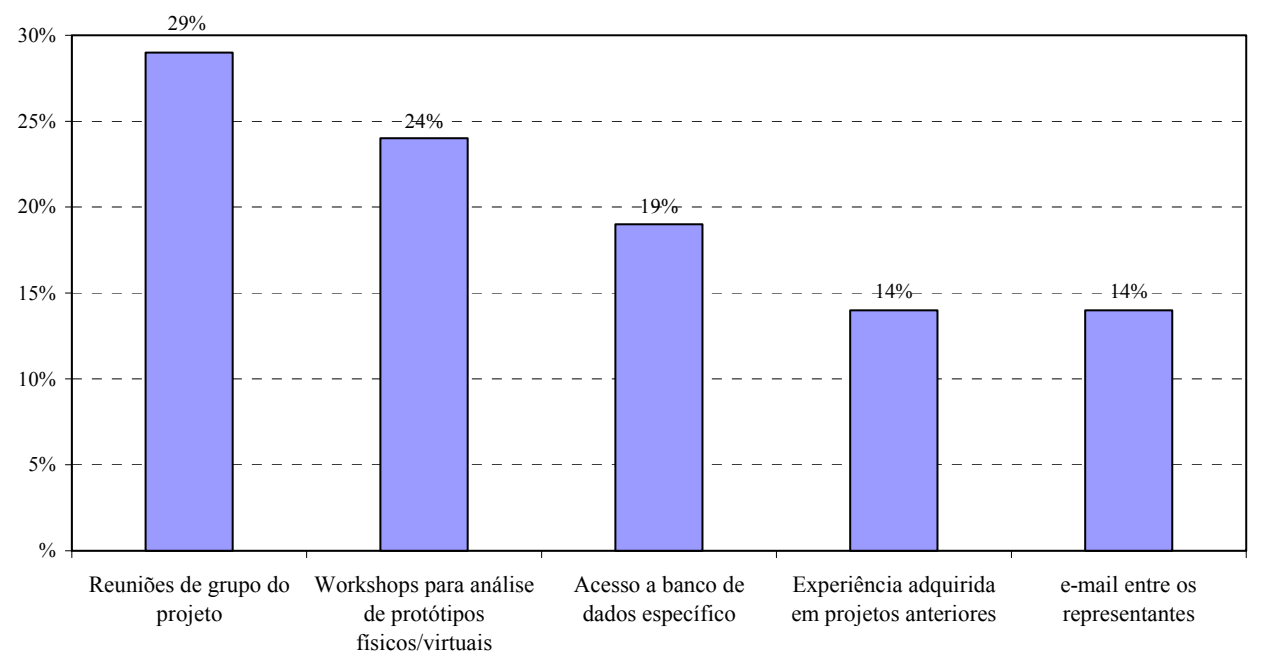

Figura 5.10 Divulgação dos requisitos de montagem

\subsubsection{A detecção de interferências através do uso de simulações}

No projeto A03, quase a totalidade das novas operações de montagem foram analisadas através das simulações virtuais, com exceção de apenas algumas interações entre os equipamentos de montagem e o produto, que não foram analisadas basicamente devido a falta de treinamento e tempo disponível no início do processo de implementação das simulações. Assim, estima-se que a grande maioria dos problemas de interferências entre os equipamentos de montagem e o produto já tenham sido detectadas pelas simulações virtuais e apenas uma pequena parcela, ao redor de $10 \%$, seriam detectadas fisicamente após a montagem dos protótipos.

O uso de simulações prevê ainda a eliminação total de interferências de equipamentos detectadas na planta de montagem, visto que os mesmos equipamentos 
previstos para a montagem do produto são simulados virtualmente no computador, durante o projeto.

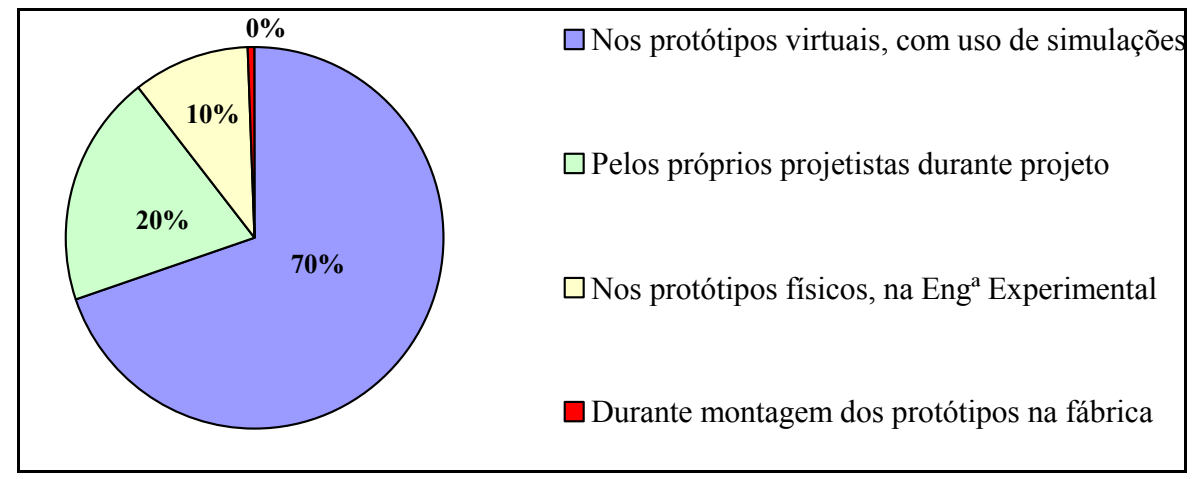

Figura 5.11 Local da detecção de interferências no Projeto A03

No caso em que as interferências de montagem são detectadas através das simulações virtuais, os entrevistados apontam como fator determinante na escolha da solução final o tempo para alteração do projeto, que normalmente é transformado em custo de mão-de-obra de engenharia, podendo assim ser comparado com os custos relativos às modificações dos equipamentos de montagem. Outro fator importante apontado na pesquisa e que deve ser considerado é o impacto causado na linha de montagem: neste caso ajudaria justificar a alteração do projeto caso o design proposto esteja ocasionando acréscimo no tempo de operação ou prejudicando a ergonomia para o operador ou ainda, exigindo alterações na seqüência de montagem e no layout da fábrica.

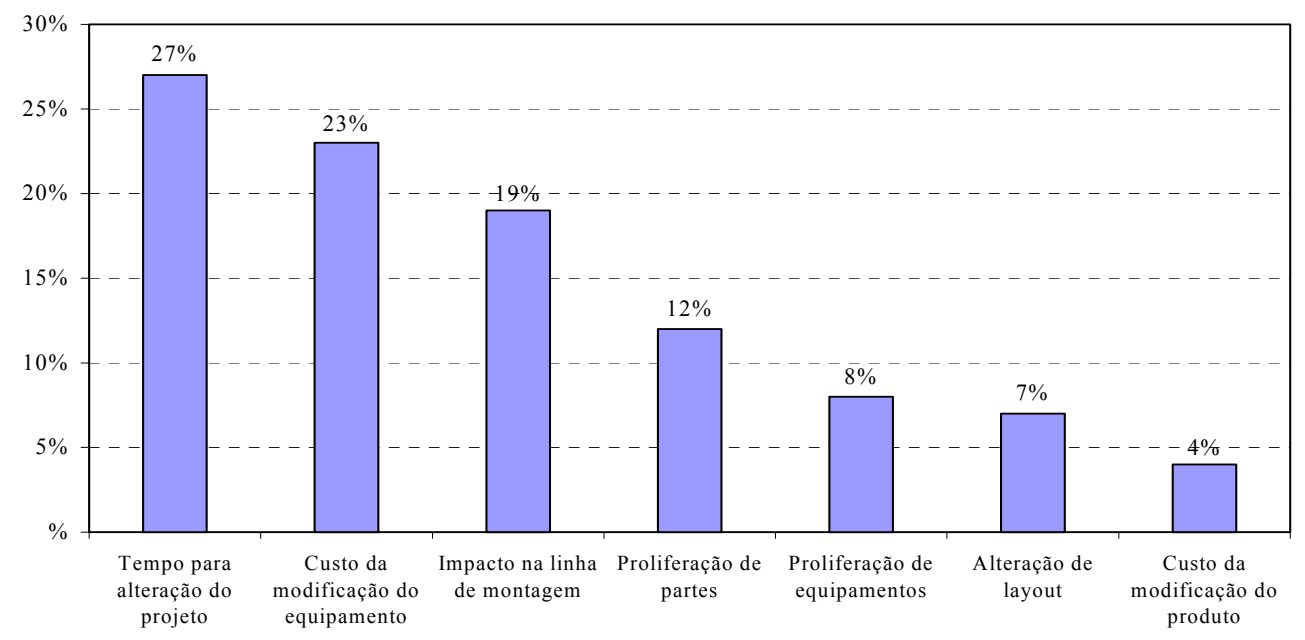

Figura 5.12 Fatores considerados na solução de interferências no Projeto A03 


\subsubsection{Dificuldades da simulação}

Segundo se pôde obter junto aos usuários dos softwares de simulações virtuais entrevistados, uma das dificuldade encontradas no processo de simulação é a insegurança na aprovação do design proposto pela Engenharia apenas virtualmente, diferentemente de como era antes, quando a Manufatura aguardava a fabricação de protótipos físicos para avaliação. Estes revelam ainda que o processo requer maior tempo para adequação e maior utilização da ferramenta e que aos poucos os usuários irão se sentindo mais confiantes nas tomadas de decisões.

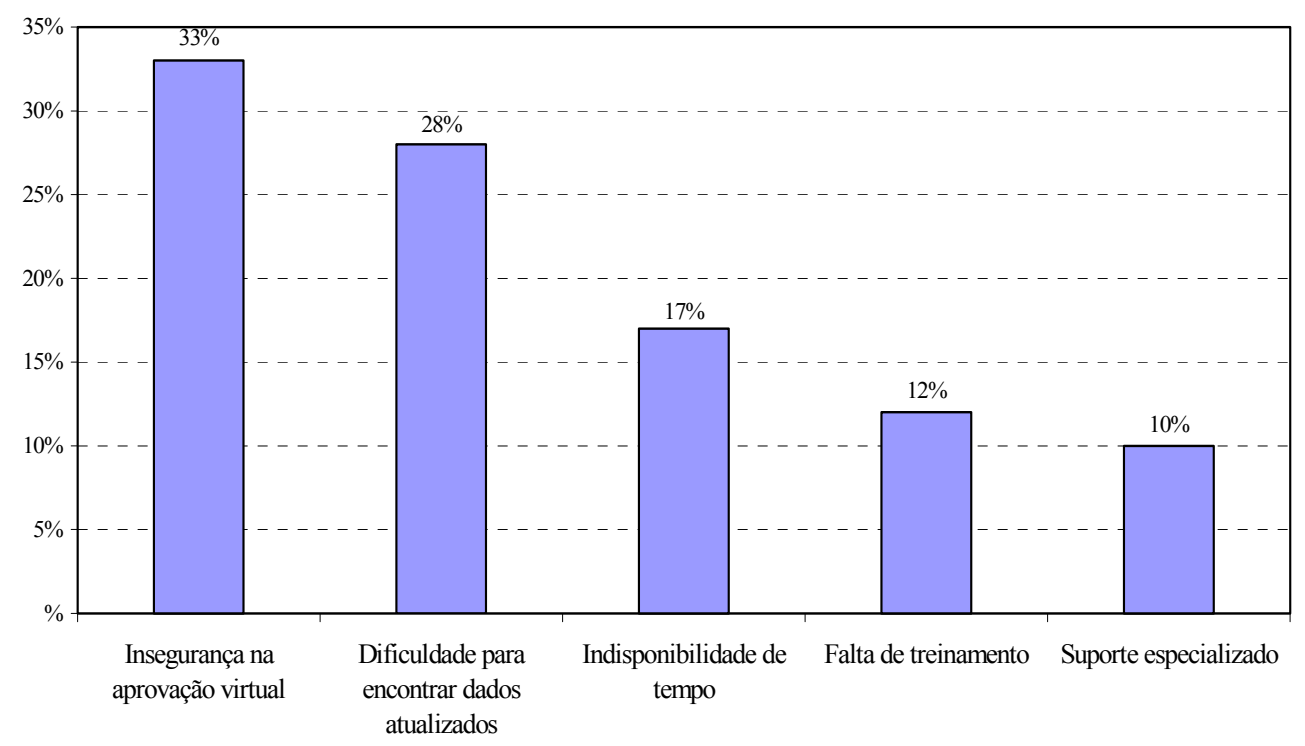

Figura 5.13 Dificuldades do processo de simulação

Também foi apontado na pesquisa a dificuldade para se encontrar todos os dados atualizados que serão utilizados nas simulações virtuais. A resolução desse problema está baseada na completa integração de todas as áreas, com o armazenamento dos dados num único local: o GMiMAN, conforme descrito anteriormente na seção 5.4.

\subsubsection{Como aumentar o uso de simulações}

Segundo os entrevistados, um dos pontos mais importantes para se aumentar o uso efetivo das simulações é uma maior divulgação dos benefícios que ela trás, não só dentro da Engenharia de Processos, mas para toda empresa. Um 
elemento importante desse processo de divulgação é a destinação de um campo específico no relatório de simulações, onde se descreve os benefícios técnicos e econômicos da aplicação das simulações virtuais dos processos de montagem de cada sistema analisado.

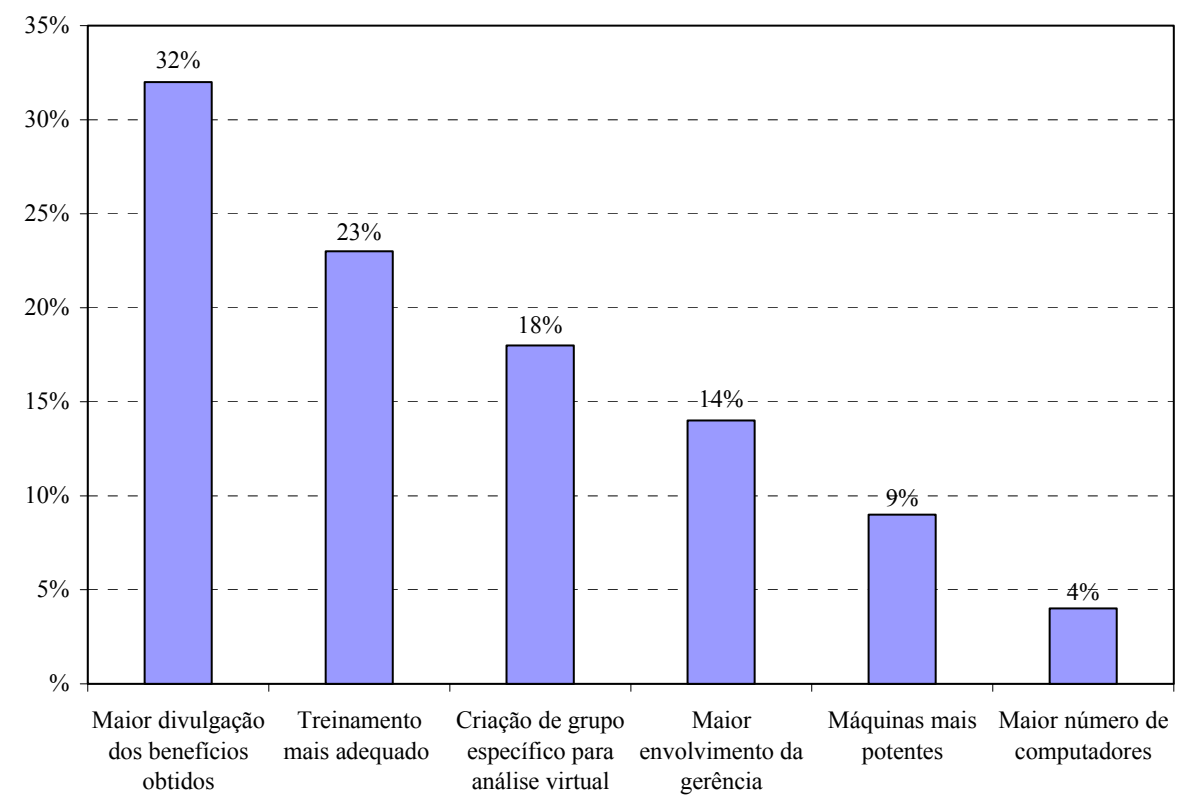

Figura 5.14 Propostas para estimular o uso de simulações

Outro item a ser considerado na busca do aperfeiçoamento do processo das simulações virtuais trata da necessidade de treinamentos mais adequados e específicos às necessidades de cada usuário, ou grupo de usuários, visto que os softwares utilizados possuem muitos recursos e que, às vezes, não são utilizados por falta de conhecimento.

\subsubsection{Avaliação das simulações realizadas no Projeto A03}

A seguir, analisamos os fatores considerados na determinação da melhor alternativa para solucionar problemas de interferências entre os equipamentos de montagem e o produto para os itens simulados no Projeto A03. No primeiro, a simulação foi realizada para a análise de possíveis interferências entre o gancho transportador de veículos e o painel inferior do veículo, como ocorrido no Projeto A16. Neste caso, entretanto, a simulação virtual mostra uma folga existente entre o 
equipamento e o veículo, indicando a capabilidade do processo produtivo para o Projeto A03.

A análise da montagem da lanterna traseira revela uma interferência entre a apertadeira e a flange do painel traseiro do veículo, onde não seria possível alterar o equipamento por já estar sendo considerado o menor equipamento disponível no mercado. Assim, tornou-se necessário a modificação do projeto, relocando a abertura de acesso e viabilizando o processo de montagem da lanterna. Devido esta interferência ter sido detectada durante o projeto, tal modificação envolveu apenas algumas horas de desenho do produto e por isso apresentou baixo custo.

\begin{tabular}{|c|c|c|c|c|c|}
\hline $\begin{array}{c}\text { ITEM } \\
\text { ANALISADO }\end{array}$ & ALTERAÇÃOO & $\begin{array}{c}\text { CUSTO } \\
\text { [\$] }\end{array}$ & $\begin{array}{c}\text { PRAZO } \\
\text { [SEM.] }\end{array}$ & $\begin{array}{l}\text { IMPACTO } \\
\text { L.MONT. }\end{array}$ & FATORES CONSIDERADOS \\
\hline $\begin{array}{l}\text { B1: Instalação } \\
\text { do eixo traseiro }\end{array}$ & $\begin{array}{c}\text { Não } \\
\text { necessária }\end{array}$ & - & - & - & $\begin{array}{l}\text { - Análise através da simulação } \\
\text { revela folga entre o equipamento } \\
\text { e o veículo. }\end{array}$ \\
\hline \multicolumn{2}{|c|}{ Solução adotada: } & \multicolumn{4}{|c|}{ Condição de montagem adequada. } \\
\hline Benefícios da & simulação: & \multicolumn{4}{|c|}{$\begin{array}{l}\text { Identificação antes da construção dos primeiros protótipos físicos, } \\
\text { evitou custos da ordem de } \$ 120.000 \text {, que seria o custo para } \\
\text { retrabalho do equipamento na linha de montagem, como ocorrido } \\
\text { no A16. A modificação do produto seria inviabilizada pelo prazo e } \\
\text { custo ainda mais elevado. }\end{array}$} \\
\hline \multirow[b]{2}{*}{$\begin{array}{l}\text { B2: Fixação da } \\
\text { lanterna traseira }\end{array}$} & Produto & 1.900 & 0,8 & - & -Horas de retrabalho do projeto \\
\hline & Equipamento & - & - & Alto & $\begin{array}{l}\text {-Não existe possibilidade de } \\
\text { alteração do equipamento, já } \\
\text { avaliado menor existente }\end{array}$ \\
\hline \multicolumn{2}{|c|}{ Solução adotada: } & \multicolumn{4}{|c|}{ Alteração do produto. } \\
\hline \multicolumn{2}{|c|}{ Benefícios da simulação: } & \multicolumn{4}{|c|}{$\begin{array}{l}\text { Identificação antes da construção dos primeiros protótipos físicos, } \\
\text { evitou custos da ordem de } \$ 50.000 \text {, que seria o retrabalho da } \\
\text { ferramenta de estampagem caso o problema fosse detectado na } \\
\text { montagem dos primeiros protótipos físicos. }\end{array}$} \\
\hline \multirow[b]{2}{*}{$\begin{array}{l}\text { B3: Fixação da } \\
\text { moldura da } \\
\text { tampa traseira }\end{array}$} & Produto & 1.500 & 0,6 & - & -Horas de retrabalho do projeto \\
\hline & Equipamento & 10.000 & - & Baixo & $\begin{array}{l}\text { - Alteração do equipamento não } \\
\text { desejada, pois é o mesmo que fixa } \\
\text { as molduras laterais }\end{array}$ \\
\hline \multicolumn{2}{|c|}{ Solução adotada: } & \multicolumn{4}{|c|}{ Alteração do produto. } \\
\hline \multicolumn{2}{|c|}{ Benefícios da simulação: } & \multicolumn{4}{|c|}{$\begin{array}{l}\text { Identificação antes da construção dos primeiros protótipos físicos, } \\
\text { evitou custos da ordem de } \$ 8.500 \text {, pois neste caso seriam } \\
\text { compradas novas apertadeiras. }\end{array}$} \\
\hline
\end{tabular}

Tabela 5.4 Quadro resumo do Estudo de Caso B - Projeto A03. 
Outro item simulado foi a fixação da moldura da tampa traseira e que apresentou uma interferência entre a apertadeira e a carroceria, impedindo a fixação do parafuso. A solução desta interferência foi a simples relocação do ponto de fixação no projeto, evitando necessidade da compra de nova apertadeira específica para esta operação.

\subsubsection{Conclusões sobre as proposições}

\section{- Proposição H1}

A pesquisa nos revela que os principais fatores considerados na solução de interferências no projeto são o tempo para a alteração do projeto e os custos envolvidos nessa modificação (vide figura 5.12). Como se pode notar na tabela 5.4, os casos estudados revelam os baixos custos e prazos de modificação do produto quando tais interferências são detectadas durante a fase de projeto através das simulações virtuais. Assim a proposição H1 é confirmada: "O crescimento $d a$ aplicação de simulações virtuais em projetos de veículos contribui para a redução de custos adicionais em equipamentos de montagem, novos ou retrabalhos de existentes".

\section{- Proposição H2}

O uso de simulações virtuais durante o desenvolvimento do projeto A03 possibilitou a análise de praticamente todas as interações entre os equipamentos de montagem e o produto, como ilustrado na figura 5.11. Assim, estima-se que a grande maioria dos problemas de interferências de montagem já tenham sido detectadas pelas simulações virtuais e apenas uma pequena parcela, algo em torno de $10 \%$, seriam detectadas durante montagem dos primeiros protótipos físicos. O uso se simulações prevê ainda que estas interferências não ocorram quando o produto chegar a planta de montagem, pois os equipamentos utilizados já foram avaliados no computador durante as simulações.

Dessa forma, confirma-se a validade da proposição H2: “O crescimento da aplicação de simulações virtuais em projetos de veículos aumenta a detecção de interferências dimensionais entre partes e equipamentos numa montagem, durante a fase de projeto". 


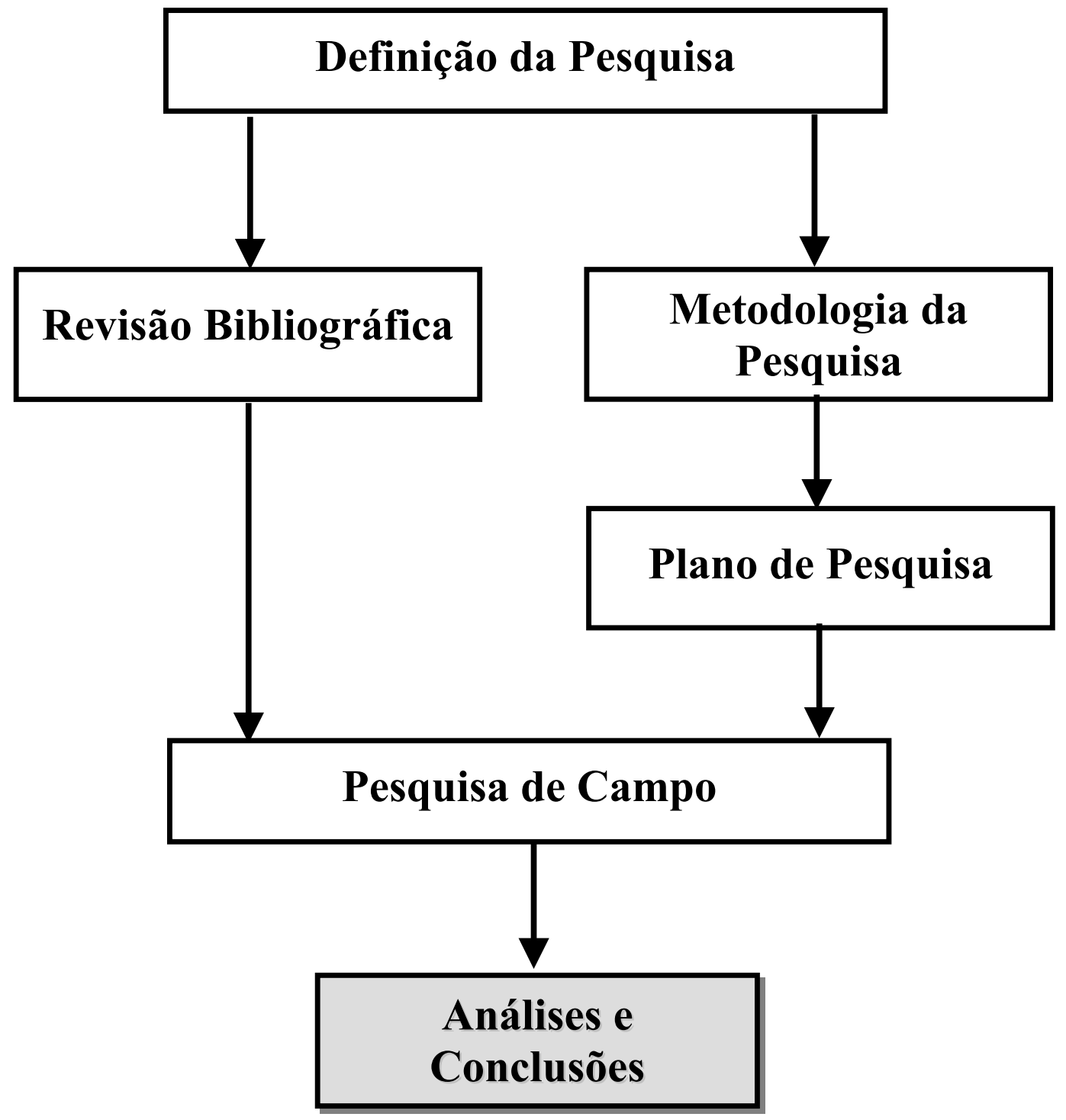




\section{CAPÍTULO 6 - CONCLUSÕES}

As principais conclusões deste trabalho estão apoiadas na própria estrutura de desenvolvimento do mesmo, ou seja, no estabelecimento de uma questão central de investigação e duas proposições a serem testadas. Também fazem parte dessa estrutura uma revisão bibliográfica do tema da pesquisa, a metodologia adotada e o projeto de pesquisa, que estabeleceu critérios para a análise dos casos e obtenção de dados através da pesquisa de campo.

\subsection{Análise das proposições}

Para responder à seguinte questão: Como as áreas de projetos e processos de empresas fabricantes de veículos automotivos podem se beneficiar dos softwares simuladores de montagem, durante as fases de projeto do produto e especificações dos processos a serem utilizados? foram estabelecidas as seguintes proposições:

- $\quad \mathbf{H}_{1}$ : "O crescimento da aplicação de simulações virtuais em projetos de veículos contribui para a redução de custos adicionais em equipamentos de montagem, novos ou retrabalhos de existentes".

Os dados obtidos nos estudos de caso A e B revelaram a contribuição das simulações virtuais para a redução de custos adicionais em equipamentos de montagem, pois a detecção de uma interferência de montagem através de simulação virtual durante o desenvolvimento do produto resulta em custos de modificação do produto inferiores a $20 \%$ dos custos de alteração dos equipamentos de montagem.

Também foi verificado que a solução de um problema de interferência detectado durante o projeto requer apenas alguns dias para a alteração do projeto, pois o desenho não está totalmente fechado e o projetista tem como solucionar com alterarações mais simples no mesmo, resultando em baixos custos. Por outro lado, uma modificação que seja necessária após a liberação dos desenhos pode levar meses para ser concluída, por requerer reprojeto dos componentes e geralmente envolver retrabalhos de ferramentas de estampagem e/ou injeção. 
Como se pode notar nos dados obtidos, as interferências detectadas na montagem dos protótipos físicos acarretam custos tão elevados de modificação do produto que a solução viável muitas vezes acaba sendo a alteração do equipamento de montagem. No entanto, deve ser analisado qual o impacto na linha de montagem causado pela alteração do equipamento para se concluir que esta é realmente a melhor solução.

- $\quad \mathbf{H}_{2}$ : "O crescimento da aplicação de simulações virtuais em projetos de veículos aumenta a detecção de interferências dimensionais entre partes e equipamentos numa montagem, durante a fase de projeto".

Como nos foi apresentado nas figuras 5.6 e 5.11 dos estudos de caso A e B, o uso de simulações virtuais aumentou a possibilidade de detecção de interferências de montagem durante o projeto, quando passamos de $40 \%$ para $90 \%$ dos casos sendo detectados virtualmente no projeto A03. Neste último, o uso de simulações virtuais permitiu a análise de praticamente todas as interações entre os equipamentos de montagem e o produto, resultando assim nesse substancial aumento da detecção de interferências durante a fase de projeto.

Dessa forma, apresenta-se no quadro abaixo a confirmação das proposições dessa pesquisa:

\begin{tabular}{|c|c|c|}
\hline Proposição & Caso A & Caso B \\
\hline $\mathbf{H}_{1}$ & Confirmada & Confirmada \\
\hline $\mathbf{H}_{2}$ & Confirmada & Confirmada \\
\hline
\end{tabular}

Tabela 6.1 Consolidação dos resultados.

\subsection{Limitações}

Algumas limitações devem ser consideradas na conclusão deste trabalho:

- Os custos e prazos para as modificações dos produtos ou dos processos de montagem que foram levantados nos casos A e B devem ser comparados apenas em 
ordem de grandeza, pois foram avaliados dois projetos diferentes e que envolveram soluções específicas, onde os componentes e processos de montagem simulados também eram diferenciados. Estes dados foram utilizados para a análise comparativa das contribuições das simulações virtuais no Projeto A03 em relação ao Projeto A16, quando não foi usada essa ferramenta para detecção de interferências de montagem.

- Devido a fase de construção de protótipos do Projeto A03 ter-se iniciado no período da conclusão desta pesquisa, não pudemos analisar a fabricação dos protótipos físicos para validar as soluções encontradas através da simulação virtual.

- E, por fim, vemos a própria limitação que a metodologia do estudo de caso impõe, impedindo que os resultados obtidos a partir de estudos de caso sejam generalizados. No entanto, os resultados da presente pesquisa podem ser adaptados e aproveitados para futuras pesquisas e aplicações práticas.

\subsection{Sugestões para pesquisas futuras}

Ao concluir esta pesquisa, tendo investigado a literatura e conduzido os estudos de casos sobre o uso de simulações virtuais para análise dos processos de montagem, o autor identifica alguns temas que poderiam ser abordados em pesquisas futuras:

- Estudos específicos das contribuições das simulações virtuais na análise de outros fatores relevantes às especificações dos processos de montagem citados neste trabalho, tais como: avaliação ergonômica, análise de seqüência de montagem, análise de layout de fábrica, entre outros.

- Análise comparativa dos cronogramas de desenvolvimento de novos produtos com a introdução das simulações virtuais na Manufatura.

- Levantamento dos custos de implantação da tecnologia de simulação virtual. 


\subsection{Considerações finais}

As técnicas digitais empregadas atualmente ao longo do desenvolvimento de novos veículos tem fornecido às empresas do ramo um ambiente totalmente virtual que melhora substancialmente as condições para tomadas de decisões quanto às expectativas dos clientes, às definições conceituais do produto e às condições operacionais da fabricação dos mesmos.

Nesse sentido, o estudo bibliográfico realizado e a análise dos casos da presente pesquisa revelaram o grande potencial da simulação virtual dentro da Engenharia de Processos de Montagem de Veículos para a análise das condições de montagem do produto durante as fases de projeto e especificações dos processos a serem utilizados. 
ANEXO A - Questionário para pesquisa de campo sobre a utilização de Simulações Virtuais na Manufatura da GMB. 


\section{ESCOLA POLITÉCNICA DA UNIVERSIDADE DE SÃO PAULO}

Mestrado Tecnológico em Engenharia Automotiva

\section{ROTEIRO PARA PESQUISA DE CAMPO}

Prezado $\operatorname{Sr}(\mathrm{a})$,

Está sendo realizada uma pesquisa para a qual a sua colaboração é essencial. A pesquisa faz parte de uma dissertação de Mestrado Profissional em Engenharia Automotiva, submetida a análise da Escola Politécnica da Universidade de São Paulo, cujo objetivo é analisar os benefícios da aplicação de simulações virtuais na detecção de interferências entre partes do veículo em desenvolvimento e os equipamentos de montagem. É importante mencionar que as respostas coletadas serão mantidas em sigilo e que os resultados serão divulgados de forma consolidada.

\section{Benefícios da adoção de simulações virtuais dos processos de montagem}

\section{Caracterização do departamento ou setor}

1.1- Informações gerais

Entrevistado

Departamento

Área de trabalho

Experiência na área

Número de funcionários da área

Número de funcionários que usam softwares de simulação

1.2- $\mathrm{O}$ uso de simulações virtuais dos processos de montagem em seu departamento está relacionado ao:

$\square$ desenvolvimento de ferramentas e dispositivos

elaboração de layout

$\boldsymbol{D}$ desenvolvimento do produto

$\square$ análise de células de trabalho

$\square$ avaliação ergonômica

análise da seqüência de montagem

identificação de interferência dos equipamentos de montagem 


\section{Caracterização geral dos projetos}

2.1- Dentre os recursos de projeto listados abaixo, quais os que mais se aprimoram tecnologicamente ou surgiram novos de um projeto para o outro?

1- Manteve grau de utilização

2- Aprimorou uso

3- Novo recurso ou aplicação é nova na GM

$\square$ Mock-up digital (DMU)

$\square$ Análise Estrutural por Elementos Finitos

Substituição de protótipos físicos por protótipos virtuais

$\square$ Simulações Virtuais dos Processos de Montagem

Layout virtual de Fábrica

$\square$ Uso de ferramentas de qualidade (DFM/A, FMEA, Engenharia

Simultânea, entre outras)

2.2- Na sua área, onde as simulações se encaixam nos cronogramas dos projetos?

$\square$ na fase de conceituação do produto

$\square$ durante desenvolvimento e desenho do produto

$\square$ após conclusão do projeto e liberação final dos desenhos

2.3- Os requisitos da Manufatura referentes aos equipamentos e processos de montagem são levados ao conhecimento dos projetistas de forma mais eficiente através de:

$\square$ acesso a banco de dados específico

$\square$ reuniões de grupo do projeto

e-mail entre os representantes

experiência obtida de projetos anteriores

$\square$ workshops para análise de protótipos físicos/virtuais

outros 


\section{Análise do não-uso de simulações - Projeto A16}

3.1- Como foram detectadas as interferências de montagem no Projeto A16, caso em que não houveram simulações na Manufatura?

_ \% foi detectado pelos próprios projetistas durante projeto

_ \% detectado no DMU na Eng ${ }^{\text {a }}$ de Produtos

_ $\%$ detectado durante construção dos protótipos físicos na Eng ${ }^{\mathrm{a}}$ Experimental

_ \% detectado durante montagem dos protótipos na fábrica

3.2- Nos casos em que a detecção de interferências entre equipamentos de montagem e o produto ocorre apenas na fase final do projeto, quais fatores são determinantes na solução final?

$\square$ custo da modificação produto $\mathrm{x}$ equipamento

$\square$ tempo para modificação do produto $\mathrm{x}$ do equipamento

$\square$ análise do impacto na linha de montagem (acréscimo de conteúdo de trabalho, ergonomia, etc)

$\square$ proliferação de partes

$\square$ proliferação de equipamentos

$\square$ alteração de layout

$\square$ outros

3.3- Como são determinados os custos totais gerados por uma interferência de montagem detectada apenas durante a construção de protótipos físicos? 


\section{Análise do uso de simulações - Projeto A03}

4.1- Como a simulação pode ajudar na melhoria dos projetos de montagem?

Marque segundo o grau de importância de acordo com a seguinte escala gradativa:

1- Nenhuma importância

2- Pequena contribuição

3- Importância moderada
4- Bastante importante

5- Importância total

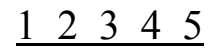

padronização de equipamentos वण्व

análise de dispositivos de montagem בם agilização no processo de liberação do trabalho פספטם autonomia da área para desenvolver trabalho वण análise de seqüência de montagem प्वण criação de banco de dados de peças

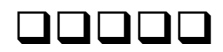
trabalho simultâneo com demais áreas פם trabalho em avançado permite melhorias do processo व

4.2- Nos casos em que há detecção de interferências entre equipamentos de montagem e o produto durante o projeto através de simulações virtuais, quais os parâmetros utilizados na determinação da solução final:

$\square$ custo da modificação do equipamento

$\square$ tempo para alteração do projeto

$\square$ análise do impacto na linha de montagem (acréscimo de conteúdo de trabalho, ergonomia, etc)

proliferação de partes

$\square$ proliferação de equipamentos

$\square$ alteração de layout

$\square$ outros 
4.3- Como são determinados os custos totais gerados por uma interferência de montagem detectada através da simulação virtual, na fase de projeto.

4.4- Quais as dificuldades encontradas pelos usuários no momento da simulação?

$\square$ indisponibilidade de tempo

$\square$ falta de treinamento

$\square$ insegurança na aprovação virtual

$\square$ dificuldade para encontrar dados atualizados

$\square$ outros

4.5- O que poderia ser melhorado para aumentar o uso efetivo das simulações?

$\square$ criação de grupo específico para análise virtual

$\square$ máquinas mais potentes

$\square$ maior número de computadores

$\square$ treinamento mais adequado

$\square$ maior envolvimento da gerência

$\square$ maior divulgação dos benefícios obtidos pela simulação

outros 
ANEXO B - Estudo de Caso A: A detecção de interferências de montagem no Projeto A16, sem o uso de simulações virtuais. 


\section{CASO A.1}

\section{Reporte de problema: INTERFERÊNCIA NA INSTALAÇÃO DO EIXO} TRASEIRO

Componente principal: EIXO TRASEIRO CONJ. - Projeto: A016

Engenheiro de Processos:

tel.

Identificado por:

tel.

Contatos adicionais:

tel.

Data de ocorrência: 31/01/2002

\section{Identificação do problema:}

Os pinos localizadores do acoplamento do eixo traseiro ao veículo não alcançam os furos na carroceria devido a uma interferência entre o gancho transportador de veículos na linha aérea e o painel inferior veículo.

\section{Especificações do projeto:}

Equipamento é acoplado automaticamente ao veículo e correntes são travadas por medida de segurança para evitar movimentação do mesmo durante acoplamento.

Para absorver as variações do processo, a folga mínima requerida entre veículo e gancho transportador é de $10 \mathrm{~mm}$

\section{Solução imediata:}

Parada da linha de montagem para permitir instalação manual com a colocação de adaptadores aos pinos localizadores do eixo traseiro.

\section{Propostas:}

1. Alteração do Produto: Necessário uma modificação na região inferior do painel lateral. A solução é inviabilizada pelos custos elevados e, principalmente, pelo comprometimento dos prazos do programa.

Custos: $\$ 200.000$

Lead time: 14 semanas.

2. Alteração do Equipamento: Retrabalho para permitir ajuste de altura dos pinos localizadores. Apesar dos custos também serem elevados, esta solução é a menos penosa e a que permite a implementação das modificações em menor tempo, sem comprometer os prazos do programa.

Custos: $\$ 120.000 \mathrm{mil}$

Lead time: 4 semanas.

\section{Solução adotada:}

Retrabalho do equipamento para permitir ajuste de altura dos pinos localizadores e acoplamento dos diferentes modelos montados na planta. Ajuste será feito pela movimentação manual de alavancas intercambiáveis. Essa modificação permite atingir a folga mínima requerida. 


\section{Conclusões:}

Como o produto já estava definido e não seria mais possível alterá-lo, foi necessário o retrabalho do equipamento existente para a realização da operação. Além dos custos diretos envolvidos com este retrabalho, neste estudo também foram consideradas as horas de engenharia para acompanhamento das modificações e as perdas devidas às paradas da linha durante a montagem dos veículos protótipos até a finalização das modificações do equipamento. Houve também um acréscimo no tempo de montagem devido ser necessária uma movimentação dos pinos pelo operador.

Ilustração/Foto do problema:

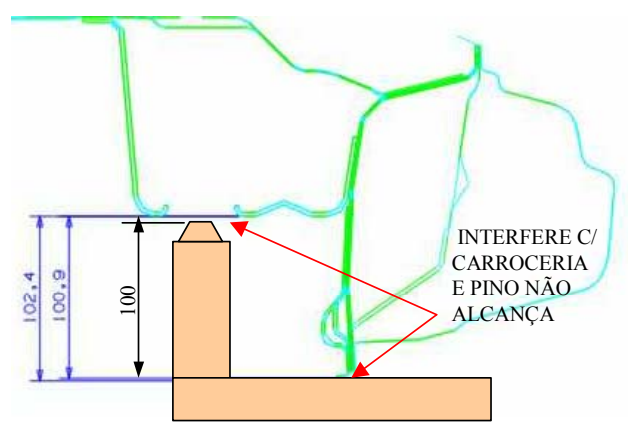




\section{CASO A.2}

Reporte de problema: INTERFERÊNCIA DA APERTADEIRA NA FIXAÇÃO DO MECANISMO LIMPADOR DO PARABRISA

Componente principal: MECANISMO LIMPADOR DO PARABRISA- Projeto: A016 Engenheiro de Processos:

tel.

Identificado por:

tel.

Contatos adicionais:

tel.

Data de ocorrência: 31/05/2002

\section{Identificação do problema:}

Interferência entre a apertadeira existente, tipo pistola, e o capô do veículo na fixação dos pontos extremos do mecanismo limpador do parabrisa.

\section{Especificações do projeto:}

A fixação de todos os pontos do mecanismo limpador ao veículo é realizada por apertadeiras pneumáticas tipo pistola.

\section{Solução imediata:}

Fixação por equipamento manual e aferição de torque de todas as unidades.

\section{Propostas:}

1. Alteração do Produto: Alteração do ângulo de fixação. Esta solução é inviabilizada por apresentar custos e prazos muito elevados.

Custos: $\$ 50.000$

Lead time: 7 semanas.

2. Alteração do Equipamento: Aquisição de duas novas apertadeiras tipo angular, de menor porte e exclusivas para atender a operação deste veículo.

Custos: $\$ 10.000$

Lead time: 8 semanas.

\section{Solução adotada:}

A solução foi o uso de apertadeiras tipo angular exclusivas para a fixação dos pontos extremos laterais do mecanismo limpador e a divisão da operação, para que fixação central seja feita posteriormente com a apertadeira tipo pistola, já que este ponto não permite acesso da apertadeira angular.

\section{Conclusões:}

A alteração do ângulo de fixação requer modificações nas ferramentas de injeção das bases de fixação do mecanismo e devido seu estágio de desenvolvimento esta solução foi inviabilizada. Apesar de não ser desejável, a proliferação do equipamento de montagem não pôde ser evitada, resultando também num acréscimo de tempo de montagem decorrente da divisão da operação em dois estágios. 


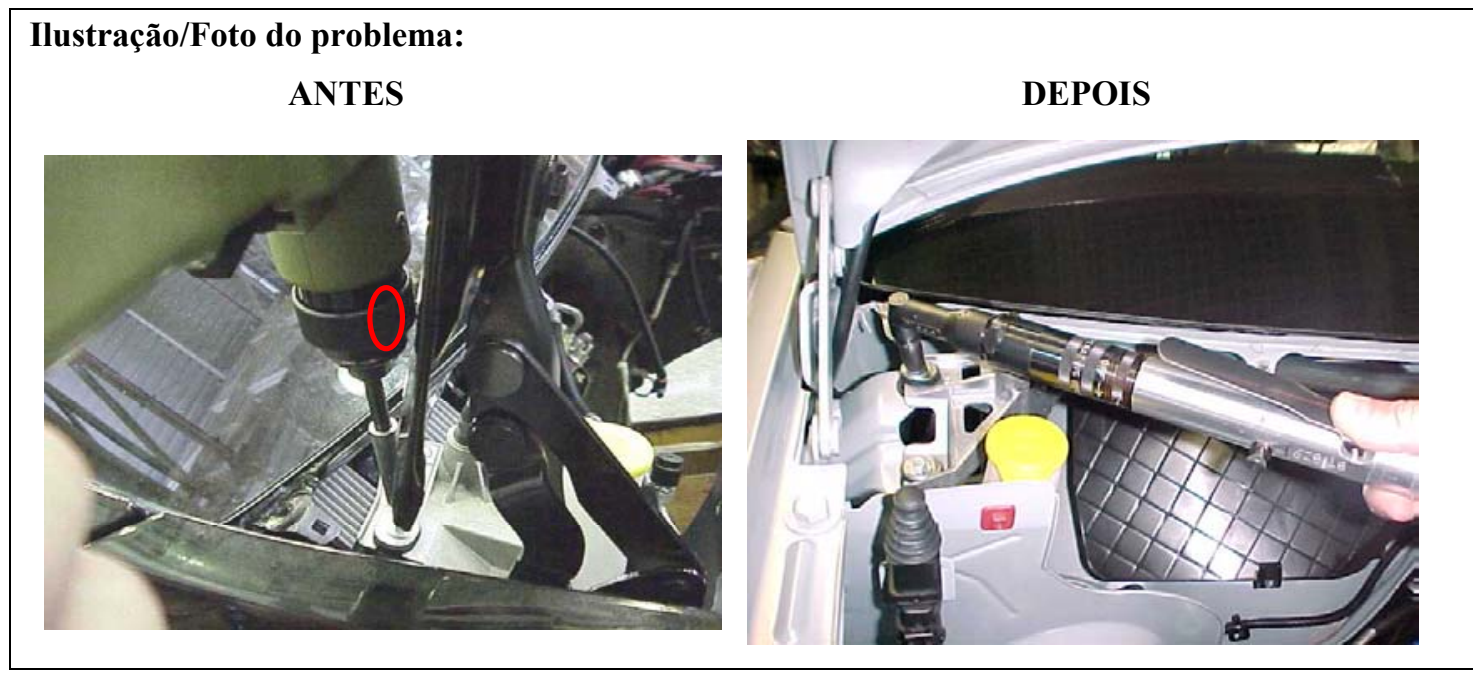




\section{CASO A.3}

Reporte de problema: INTERFERÊNCIA DA APERTADEIRA NA FIXAÇÃO DA TAMPA DA CAIXA DE RELÊS

Componente principal: TAMPA CAIXA DE RELÊS - Projeto: A016

Engenheiro de Processos:

tel.

Identificado por:

tel.

Contatos adicionais:

tel.

Data de ocorrência: 06/12/2000

\section{Identificação do problema:}

Interferência entre a apertadeira existente para a fixação da tampa da caixa de relês e um suporte soldado na carroceria do veículo.

\section{Especificações do projeto:}

Apertadeira pneumática tipo pistola é utilizada na fixação de todos pontos da tampa à caixa de relês.

\section{Solução imediata:}

Fixação por equipamento manual e aferição dos torques de todas as unidades.

\section{Propostas:}

1. Alteração do Produto: A proposta levantada foi a alteração do ângulo de montagem ou a posição de um dos parafusos. Esta proposta foi inviabilizada por apresentar custos e prazos muito elevados Custos: $\$ 65.000$ Lead time: 10 semanas.

2. Alteração do Equipamento: Aquisição de nova apertadeira tipo angular, de menor porte e exclusiva para atender a esta operação.

Custos: $\$ 5.000$

Lead time: 8 semanas.

\section{Solução adotada:}

Uso de apertadeira tipo angular exclusiva para a fixação da tampa da caixa de relês deste veículo.

\section{Conclusões:}

A alteração do ângulo de fixação ou a relocação do ponto de fixação para permitir acesso da apertadeira existente requer modificações nas ferramentas de injeção da tampa e da caixa de relês. Devido o estágio de desenvolvimento desses componentes, essa proposta é inviabilizada e apesar de não ser desejável, a proliferação da ferramenta de montagem não pôde ser evitada, pois para os outros veículos a apertadeira pistola deverá ser mantida. 


\section{Ilustração/Foto do problema:}

ANTES

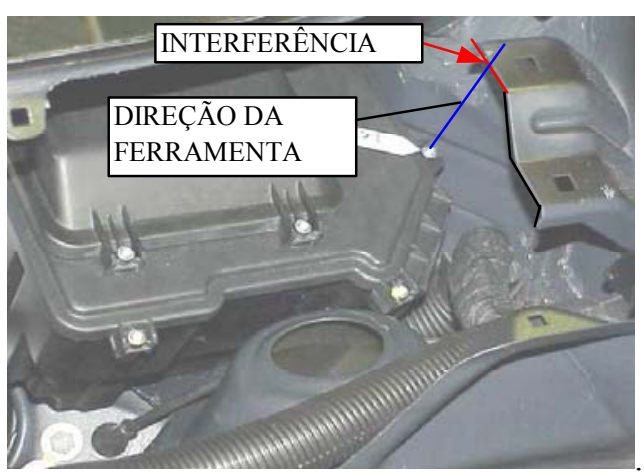

DEPOIS

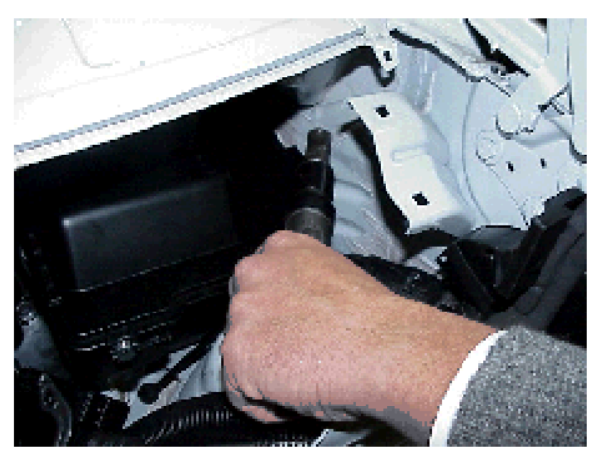




\begin{abstract}
ANEXO C - Estudo de Caso B: A adoção de simulações virtuais no Projeto A03, para detecção de interferências de montagem.
\end{abstract}




\section{CASO B.1}

Identificação da Simulação: ANÁLISE DA INSTALAÇÃO DO EIXO TRASEIRO

Componente principal: EIXO TRASEIRO CONJ. - $\quad$ Projeto: A03

Engenheiro de Processos:

Simulado por:

tel.

tel.

Contatos adicionais:

Data de início: 31/05/2002

tel.

Data de término:31/05/2002

\section{Objetivos da simulação:}

Avaliar possíveis interferências entre o equipamento gancho transportador de veículos na linha aérea e o painel inferior do veículo, quando os pinos localizadores do acoplamento do eixo traseiro ao veículo devem alcançar os furos da carroceria.

\section{Especificações do projeto:}

Equipamento é acoplado automaticamente ao veículo e correntes são travadas por medida de segurança para evitar movimentação do mesmo durante acoplamento.

A folga mínima requerida entre veículo e gancho transportador é de $10 \mathrm{~mm}$ para absorver variações do processo.

\section{Equipamentos:}

Utilizado informações atualizadas do gancho transportador e pinos localizadores.

\section{Resultados:}

Folga existente entre o gancho transportador e a parte inferior do veículo é de $10 \mathrm{~mm}$ na condição final de inserção dos pinos localizadores do acoplamento do eixo traseiro nos furos da carroceria do veículo.

\section{Ilustração da simulação:}

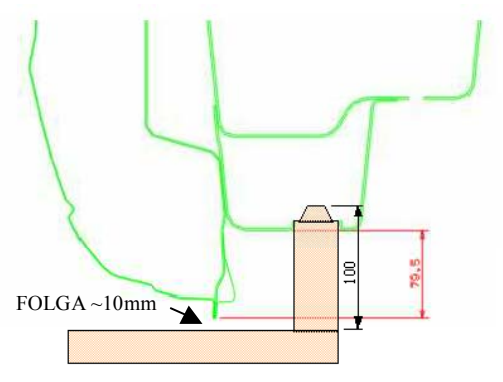

\section{Conclusões:}

A análise das seções mostra folga existente entre veículo e equipamento maior que o mínimo requerido pelo processo, indicando que o processo existente é capaz e que não haverá custos adicionais para o processo de montagem do eixo traseiro do Projeto A03. 


\section{CASO B.2}

Identificação da Simulação: ANÁLISE DA FIXAÇÃO DA LANTERNA TRASEIRA

\section{Componente principal: LANTERNA TRASEIRA CONJ. - Projeto: A03}

Engenheiro de Processos:

Simulado por:

tel.

tel.

Contatos adicionais:

Data de início: 14/06/2002

tel.

Data de término: $14 / 06 / 2002$

\section{Objetivos da simulação:}

Avaliar o acesso do equipamento de montagem da lanterna traseira no painel traseiro do veículo.

\section{Especificações do projeto:}

A lanterna se autolocaliza no painel traseiro e deve ser fixada com três parafusos, conforme torques especificados.

\section{Equipamentos:}

Utilizado modelo 3D da apertadeira existente na planta para esta operação, conforme disponível no catálogo de ferramentas virtuais. Apertadeira a bateria tipo pistola com extensão e ponta adaptadora.

\section{Resultados:}

A simulação revela uma interferência de $3 \mathrm{~mm}$ entre a apertadeira e a flange da abertura no painel interno traseiro, no eixo de fixação do parafuso.

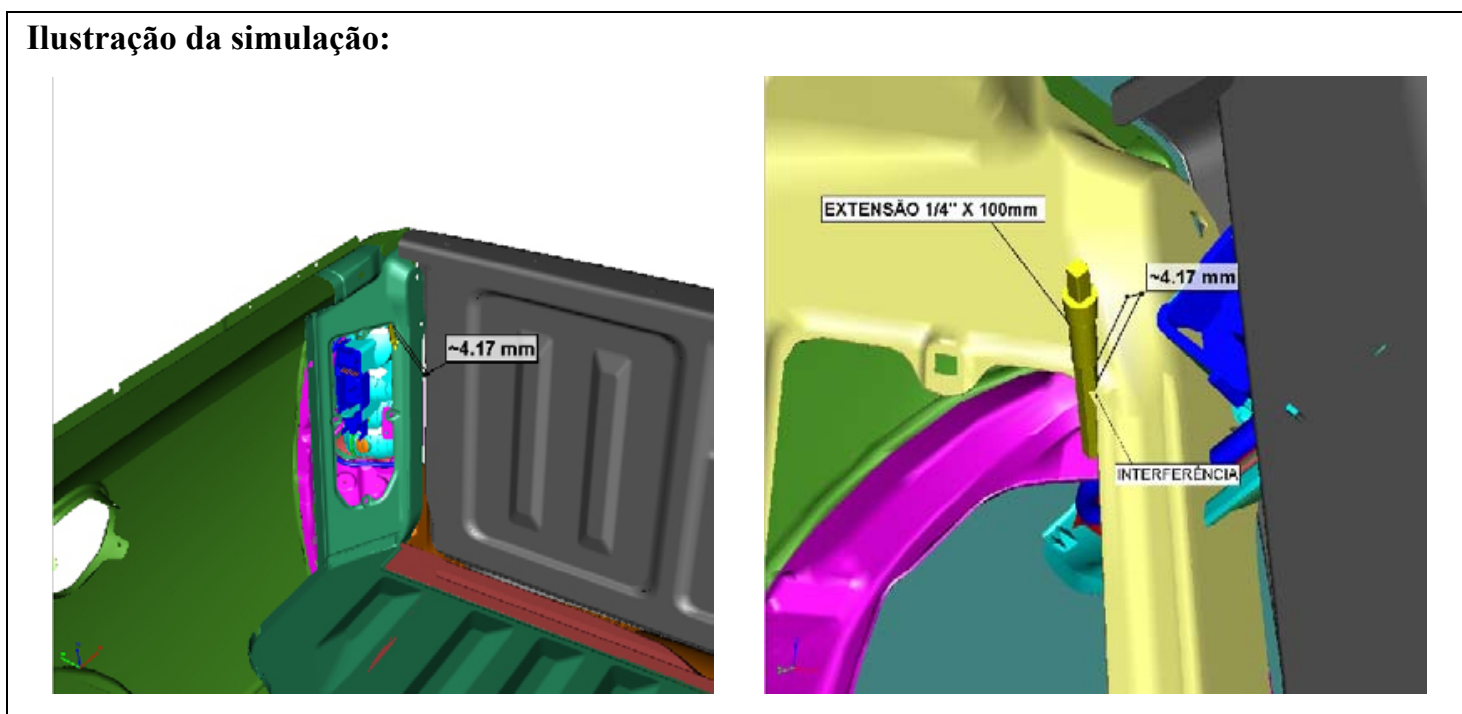

\section{Conclusões:}

A análise mostra uma interferência entre o equipamento de fixação da lanterna e o painel traseiro do veículo. A condição é inaceitável para o processo de montagem da lanterna. 


\section{Solução adotada:}

Novos estudos foram realizados e a solução encontrada foi o reposicionamento da abertura existente no painel trraseiro, a fim de permitir livre acesso do soquete, com uma folga aceitável de $2 \mathrm{~mm}$.

\section{Ilustração da solução:}
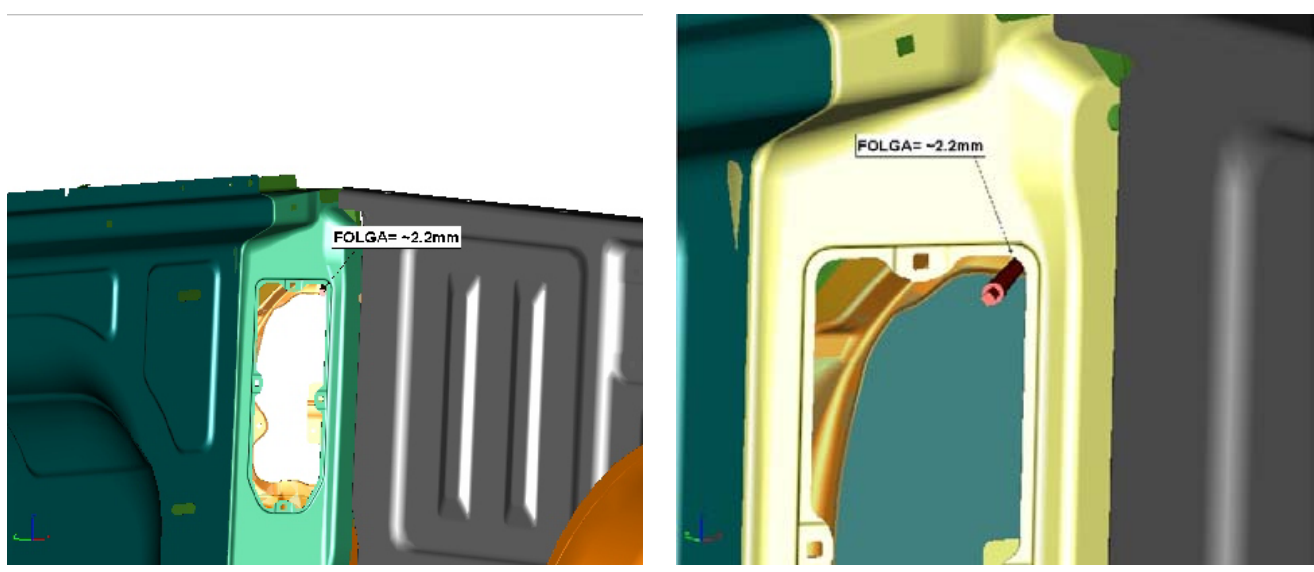

\section{Benefícios:}

O estudo virtual auxilia na determinação de um processo de montagem eficiente e capaz para a lanterna traseira. A detecção dessa interferência somente após a montagem física dos protótipos ocasionariam custos estimados de alteração do produto da ordem de $\$ 50.000$, com prazo de implementação entre 6 e 8 semanas. 


\section{CASO B.3}

Identificação da Simulação: ANÁLISE DA FIXAÇÃO DA MOLDURA TAMPA TRAS

Componente principal: MOLDURA TAMPA TRASEIRA - Projeto: A03

Engenheiro de Processos:

tel.

Simulado por:

tel.

Contatos adicionais:

tel.

Data de início: 13/05/2002

Data de término: 14/05/2002

\section{Objetivos da simulação:}

Avaliar o acesso do equipamento de fixação das extremidades da moldura superior traseira à tampa do veículo.

\section{Especificações do projeto:}

A moldura é posicionada por pinos localizadores e clipada no painel externo da tampa traseira do veículo. Em seguida, deve ser fixada com um parafuso de cada lado, conforme torques especificados.

\section{Equipamentos:}

Utilizado modelo 3D da apertadeira existente na planta para esta operação, conforme disponível no catálogo de ferramentas virtuais. Apertadeira a bateria tipo pistola com extensão e ponta adaptadora.

\section{Resultados:}

Simulação revela uma interferência de $3 \mathrm{~mm}$ entre a apertadeira e a flange da abertura no painel interno traseiro, no eixo de fixação do parafuso.

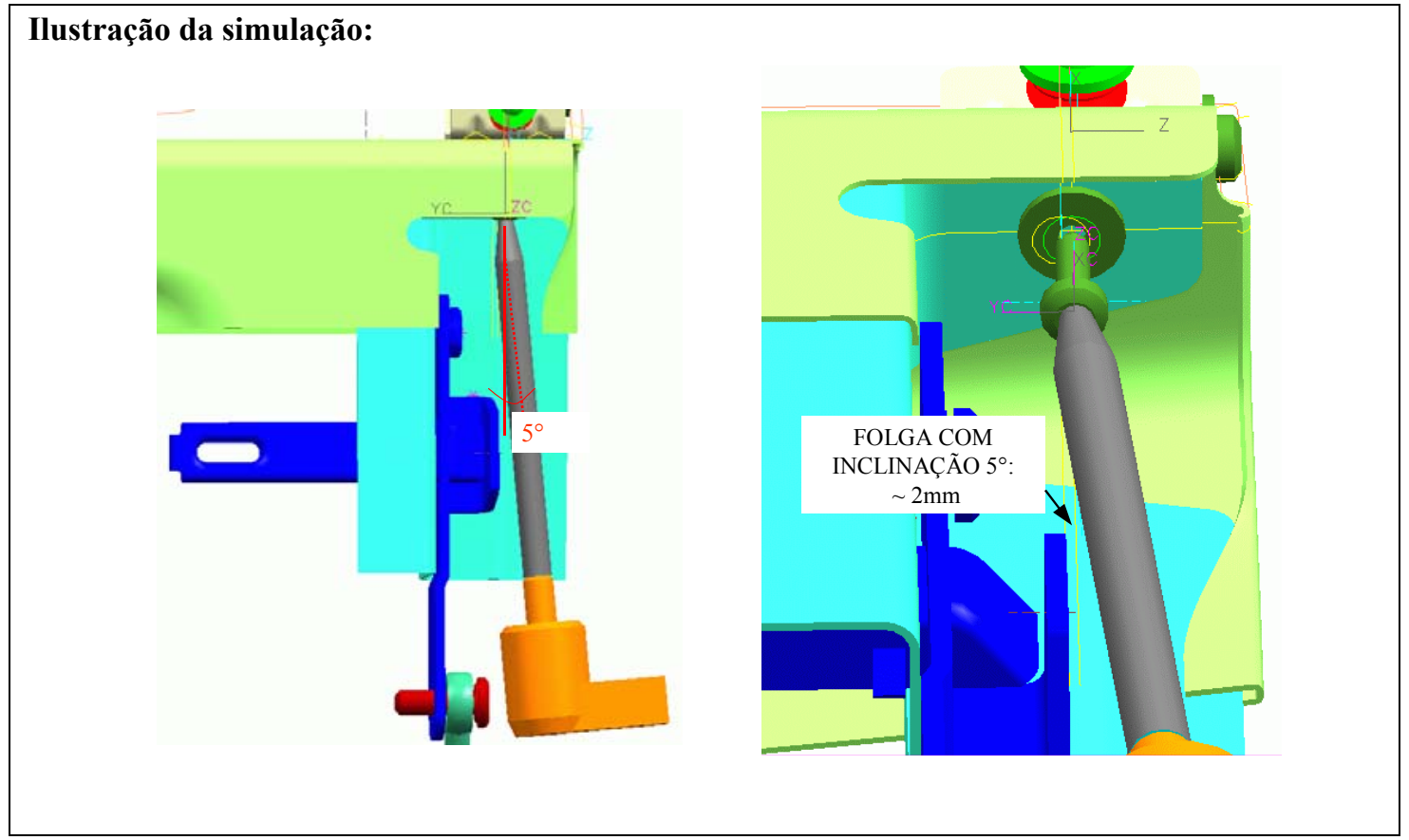




\section{Conclusões:}

A análise mostra uma interferência entre a apertadeira e os componentes da tampa, já fixados numa operação anterior. A ilustração revela necessidade de inclinação da apertadeira em relação ao eixo de fixação do parafuso em aproximadamente 5 graus. Tal condição é inaceitável para o processo de montagem, devido ocasionar desgastes da cabeça do parafuso e/ou da ferramenta.

\section{Solução adotada:}

Novos estudos foram realizados e a solução encontrada foi o deslocamento dos pontos de fixação para as extremidades da tampa, o que permitiu o livre acesso da apertadeira, com folga aceitável de $3 \mathrm{~mm}$.

\section{Ilustração da solução:}
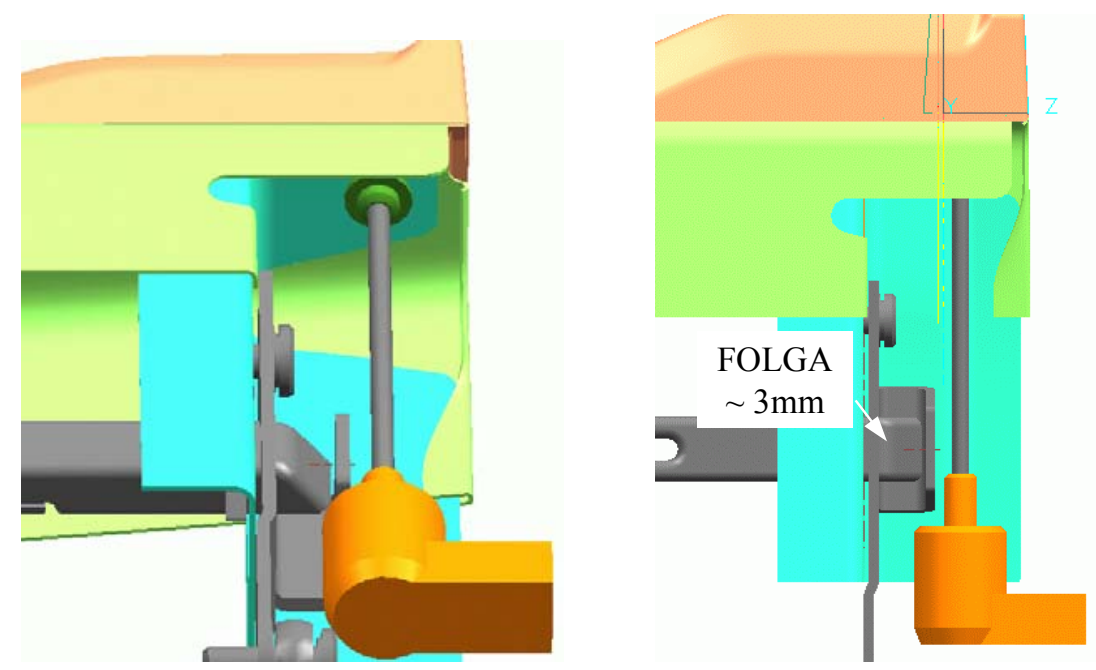

\section{Benefícios:}

O estudo virtual auxilia na determinação de um processo de montagem eficiente e capaz para a moldura da tampa traseira deste veículo. A identificação deste problema antes da construção dos primeiros protótipos físicos evitou a proliferação de equipamentos e acréscimo de custos da ordem de $\$ 8.500$, pois neste caso seriam compradas novas apertadeiras. 


\section{REFERÊNCIAS BIBLIOGRÁFICAS}

ANDREASEN, M.M.; KÄHLER, S.; LUND, E.T. Design for assembly. 2.ed. UK: IFS Publications, 1988.

ARDAYFIO, D.D. Manufacturing process simulation in proactive design for quality. DaimlerChrysler Corp., 2000. SAE Paper No 2000-01-1280.

BANKS, J.; CARSON, J.S.; NELSON B.L. Discrete-event system simulation. 2.ed. Upper Saddle River, New Jersey: Prentice Hall, 1995.

BARBARÁN, G.M.C. Indicadores de desempenho para a avaliação do desenvolvimento de projetos nas indústrias de softwares. 1999. 133p. Dissertação (Mestrado) - Escola Politécnica, Universidade de São Paulo. São Paulo.

BOOThroYD, G.; DEWHURST; P.; KNIGHT, W. Product design for manufacture and assembly. New York: Marcel Dekker Inc, 1994.

BRALLA, J.G.(Ed.) Handbook of product design for manufacturing. New York: McGraw-Hill, 1986.

BRALLA, J.G. Design for excellence. New York: McGraw-Hill, 1996.

BRATley, P.; FOX, B; SCHRAGE, L. A guide to simulation. New York: Springer-Verlag Inc, 1993.

BRYMAN, A. Research methods and organization studies. London and New York: Routledge, 1989.

CARRIE, A. Simulation of manufacturing systems. New York: John Wiley and Sons, 1988.

CHALMERS, R.E. Better assembly through simulation. Manufacturing Engineering, Dearborn, v.123, n.3, p.62-68, Sept. 1999. 
CONRAD, C.J. Assembly automation: the virtual and the physical. Manufacturing Engineering, v.119, n.3, p.62-66, Sept. 1997.

DELCHAMBRE, A. Computer-aided assembly planning. London: Chapman \& Hall, 1992.

DUHOVNIK, J. et al. Development of new products in small companies. Concurrent Engineering: research and applications, v.9, n.3, p.191-210, Sept. 2001.

FRANKEL, E.G. Project management in engineering services and development. New York: Butterworths, 1990.

GARSIDE, J. Rapid progress in manufacturing. Engineering Manufacture, London, v.215, n.4, p.441-452, Apr. 2001.

GENERAL MOTORS DO BRASIL. São Caetano do Sul. Apresenta informações e dados institucionais. Disponível em: $<\mathrm{http}: /$ www.gmcenter.com.br $>$. Acesso em 26 de maio de 2002.

GIL, A.C. Como elaborar projetos de pesquisa. 3.ed. São Paulo: Atlas, 1996.

GREEN, P.; TULL, D.; ALBAUR, G. Research for marketing decisions. 5.ed. New Jersey: Prentice Hall, 1988.

KAMINSKI, P.C. Desenvolvendo produtos com planejamento, criatividade e qualidade. Rio de Janeiro: Livros Técnicos e Científicos Editora S.A., 2000.

MIDDENDORF, W.H. Design of devices and systems. 2.ed. New York: Marcel Dekker Inc, 1990.

MARIBONDO, J.F.; BACK, N.; FORCELLINI, F.A. Diretrizes para o desenvolvimento de uma metodologia de projeto de sistemas modulares. In: CONGRESSO BRASILEIRO DE ENGENHARIA MECÂNICA, 15., São Paulo, COBEM'99. São Paulo, 1999. 
PRITSKER, A.A.B. Introduction to simulation and SLAM II. 3.ed. New York: Systems Publishing Corporation, 1986.

PROJECT MANAGEMENT BOOK OF KNOWLEDGE. Trad. livre do PMBOK V1.0: disponibilizado através da internet pelo Project Management Institute, Minas Gerais, Brasil, em abril de 2001. Disponível em: $<$ http://www.pmimg.org.br $>$.

REVISTA PRODUTOS E SERVIÇOS. São Paulo: Banas, dez. 2000. Edição especial: fábrica do futuro.

ROMEIRO FILHO, E. O setor de projetos e as novas tecnologias: elementos para uma discussão. In: CONGRESSO BRASILEIRO DE GESTÃO DE DESENVOLVIMENTO DE PRODUTO, 2., São Carlos, 2000. Anais...São Carlos: UFSCar, 2000. p.88-95.

ROZENFELD, H.; AMARAL, D.C. O processo de desenvolvimento de produtos. Fábrica do Futuro - Produtos e Serviços, São Carlos, n.312, p.55-64, dez. 2000. SCHÜTZER, K.; SOUZA, N.L. Implantação do "digital mockup" na indústria automobilística: conquistando vantagens competitivas. In: CONGRESSO BRASILEIRO DE GESTÃO DE DESENVOLVIMENTO DE PRODUTO, 1., Belo Horizonte, 1999. Anais...Belo Horizonte, Brasil, 1999. p.305-314.

SLACK, N. Vantagem competitiva em manufatura: atingindo competitividade nas operações industriais. Trad. de Sônia M. Correa. São Paulo: Atlas, 1993.

SOUSA, A.G.; FORCELLINI, F.A.; BACK, N. Estudo de caso sobre a avaliação da montabilidade no desenvolvimento de produtos. In: CONGRESSO BRASILEIRO DE ENGENHARIA MECÂNICA, 15., São Paulo, COBEM'99. São Paulo, 1999.

SOUSA, A.G. Estudo e análise dos métodos de avaliação da montabilidade de produtos industriais no processo de projeto. 1998. 238p. Dissertação (Mestrado) - Universidade Federal de Santa Catarina. Florianópolis.

THAMHAIN, H.J. Engineering management: managing effectively in technology-based organizations. John Wiley \& Sons Inc., 1992. 
TRUCKS, H.E. Designing for economical production. Society of Manufacturing Engineers, 1987.

ULLMAN, D.G. The mechanical design process. New York: McGraw-Hill, 1992.

UNIVERSIDADE DE SÃO PAULO. Diretrizes para apresentação de dissertações e teses. 2001. 39p. Escola Politécnica da Universidade de São Paulo Serviço de Bibliotecas. São Paulo.

VILELA, J.B. et al. Desenvolvimento virtual do produto". In: CONGRESSO BRASILEIRO DE GESTÃO DE DESENVOLVIMENTO DE PRODUTO, 2., São Carlos, 2000. Anais...São Carlos: UFSCar, 2000.

WHITNEY, D.E. Manufacturing by design. The new manufacturing. Boston: Harvard Business School Press, p.125-133, 1991.

WHITNEY, D.E. et al. Designing assemblies. Research in engineering design. London: Springer-verlag, v.11, n.4, p.229-253, 1999.

WILSON, B.A. Design dimensioning and tolerancing. South Holland, Illinois: The Goodheart-willcox Company, 1996.

YIN, R.K. Case study research: design and methods. 2.ed. California: Sage Publications Inc, 1994. 